\author{
UNIVERSIDADE DE SÃO PAULO \\ Faculdade de Zootecnia e Engenharia de Alimentos
}

\author{
JULIANA CRISTINA BALDIN
}

\begin{abstract}
AVALIAÇÃO DO POTENCIAL ANTIMICROBIANO E ANTIOXIDANTE DO EXTRATO DE JABUTICABA (Myrciaria cauliflora) MICROENCAPSULADO ADICIONADO EM LINGUIÇA FRESCAL E MORTADELA
\end{abstract}




\section{AVALIAÇÃO DO POTENCIAL ANTIMICROBIANO E ANTIOXIDANTE DO EXTRATO DE JABUTICABA (Myrciaria cauliflora) MICROENCAPSULADO ADICIONADO EM LINGUIÇA FRESCAL E MORTADELA}

"Versão corrigida"

Tese apresentada à Faculdade de Zootecnia e Engenharia de Alimentos da Universidade de São Paulo, como parte dos requisitos para a obtenção do Título de Doutor em Ciências.

Área de Concentração: Ciências da Engenharia de Alimentos.

Orientador: Prof. Dr. Marco Antonio Trindade Co-Orientadora: Profa. Dra. Andrezza Maria Fernandes 
Ficha catalográfica elaborada pelo Serviço de Biblioteca e Informação, FZEA/USP, com os dados fornecidos pelo(a) autor(a)

B177a Baldin, Juliana Cristina

B177a Avaliação do potencial antimicrobiano e antioxidante do extrato de jabuticaba (Myrciaria cauliflora) microencapsulado adicionado em linguiça ... / Juliana Cristina Baldin ; orientador Marco Antonio Trindade; coorientadora Andrezza Maria Fernandes. -- Pirassununga, 2016.

$100 \mathrm{f}$.

Tese (Doutorado - Programa de Pós-Graduação em Engenharia de Alimentos) -- Faculdade de Zootecnia e Engenharia de Alimentos, Universidade de são Paulo.

1. Embutidos. 2. Estabilidade. 3. Microbiologia. 4. Corantes. 5. Deterioração de alimentos. I. Trindade, Marco Antonio, orient. II. Fernandes, Andrezza Maria, coorient. III. Título.

Permitida a cópia total ou parcial deste documento, desde que citada a fonte - o autor 
Dedico este trabalho às pessoas maravilhosas e especiais da minha vida:

Aos meus pais João e Cecília por todo amor e toda paciência aceitando minhas decisões e me apoiando sempre...

Ao meu namorado Euder pela paciência, dedicação, puxões de orelha e todo amor!!! Aos meus irmãos Isabel e João Carlos pelo apoio e carinho...

À minha vózinha Lourdes por ser sempre adorável... 


\section{AGRADECIMENTOS}

À Deus pelo dom da vida, pelas bençãos e oportunidades concedidas.

Ao meu orientador Prof. Dr. Marco Antonio Trindade (Tonhão) pela oportunidade e privilégio de ser sua primeira aluna de doutorado, pela confiança depositada, por toda ajuda, amizade, orientação, paciência, pelos ensinamentos que com certeza levarei para vida toda. Meu muito obrigada!

À minha co-orientadora Profa. Dra. Andrezza Maria Fernandes por ter me dado a oportunidade de estar aqui na pós-graduação e ter me apresentado para o professor Tonhão, por toda ajuda, confiança, ensinamentos, paciência, oportunidades e orientação. Serei eternamente grata a você!

À Profa. Dra. Carmen Sílvia Fávaro-Trindade pela ajuda, apoio e valiosas contribuições para enriquecimento desta pesquisa.

Ao Prof. Dr. Ricardo Luiz Moro de Sousa por ser sempre prestativo e por toda ajuda.

Aos professores Dra. Maria Teresa Freire, Dr. Rodrigo Petrus, Dra. Judite Guimarães, Dra. Eliana Kamimura, Dra. Rosemary de Carvalho, Dr. Paulo do Amaral Sobral pelo empréstimo de laboratórios e pelos ensinamentos concedidos.

Às professoras Dra. Ana Maria Centola Vidal e Dra. Vera Letticie de Azevedo Ruiz pela oportunidade em participar do Programa de Aperfeiçoamento ao Ensino (PAE), pelos conselhos e ensinamentos.

Ao Prof. Dr. César Gonçalves de Lima pela paciência e auxílio nas análises estatísticas.

Aos membros da banca Profa. Dra. Andréa Barreto, Profa. Dra. Marta Mitsui, Dra. Kátia Cipolli e Dra. Flávia Vargas pelas excelentes colaborações e pelas valiosas sugestões.

Às minhas melhores estagiárias: Thaís, Karen, Maria Luiza, Keila, Carol, Ju Sarti, Letícia, Marina, Poliana (TT) e Ju Tamura por toda dedicação, pelo auxílio nos experimentos, pelas conversas e amizade, sem vocês não seria nada fácil.

À técnica do lab de micro Silvia Helena de Godoy pelo reencontro depois de tantos anos, por toda ajuda e disposição em sempre resolver qualquer problema, pelas conversas e pela amizade que o tempo não desfez. 
Aos técnicos e especialistas de laboratório: Nilson, Marcelo, Camila, Carla, Fabio, Guilherme e Tatiane pelos ensinamentos e toda ajuda prestada, meu muito obrigada.

Ao meu namorado Euder por toda paciência, todo amor e por sempre me ajudar e me socorrer na finalização dos experimentos.

Aos meus pais e irmãos por toda confiança, carinho, paciência, por sempre me apoiarem em todas minhas decisões.

Aos amigos do Laqueca: Yana, Raul, Isabela, Larissa, Manoela, Paulo e Julliane por toda ajuda, pelas conversas, happy hour, churrascos e enfim pela equipe formada. Que a união seja sempre nossa força! Valeu pessoal!

Aos amigos do lab de micro: Annie, Sabrina, Marisa, Ju Navarro, Eurico, Samara, Mel, Marina, Maria Fernanda e Andréa pela amizade, pelos momentos de descontração e preciosos cafés. Muito obrigada galera!

Às meninas que me acolheram Lisia, Natalia e Erika pela amizade e experiência vivida.

À minha grande amiga Lucimara Borges (Pinga) muito obrigada pelos conselhos, pela ajuda sempre, pela amizade e confiança.

À minha amiga Gisele Jiopato pelos conselhos e pela sua amizade, você sabe o quanto é importante e especial para mim, não seria nada fácil sem nossas conversas.

Aos colegas de pós-graduação, em especial ao Volnei, Flávia, Talita, Fernando, Mariana, Marília, que fizeram esta caminhada ser mais leve e proveitosa.

À família de jabuka: República Abduzidas pelo apoio e amizade sempre.

À toda equipe do Matadouro-escola da FZEA/USP pela ajuda e disponibilidade durante os processamentos dos produtos cárneos. Valeu pessoal.

Aos funcionários da biblioteca por toda ajuda prestada.

À CAPES pela bolsa concedida para a realização deste trabalho.

À FAPESP pelo auxílio concedido e a possibilidade de realização deste trabalho.

Aos demais professores, funcionários e colegas pela feliz convivência.

A todos os amigos que encontrei nesta caminhada o meu muito obrigada! 
"Talvez não tenha conseguido fazer o methor, mas lutei para que o melhor fosse feito. $\mathcal{N a ̃ o ~ s o u ~ o ~ q u e ~ d e v e r i ́ a ~ s e r , ~ m a s ~ g r a c ̧ a s ~ a ~ D e u s , ~ n a ̃ o ~}$ sou o que era antes. " (Martin Luther King) 


\section{RESUMO}

\section{BALDIN, J.C. Avaliação do potencial antimicrobiano e antioxidante do extrato de}

jabuticaba (Myrciaria cauliflora) microencapsulado adicionado em linguiça frescal e mortadela. 2016. 100f. Tese (Doutorado) - Faculdade de Zootecnia e Engenharia de Alimentos (FZEA), Universidade de São Paulo, Pirassununga, 2016.

O objetivo do presente estudo foi utilizar o extrato de jabuticaba microencapsulado como corante e avaliar o seu potencial antimicrobiano e antioxidante em produtos cárneos embutidos do tipo linguiça frescal e mortadela, em substituição ao corante tradicionalmente utilizado carmim de cochonilha. Uma primeira etapa consistiu na avaliação in vitro da capacidade antioxidante e antimicrobiana do extrato de jabuticaba aquoso e microencapsulado. $O$ extrato de jabuticaba foi obtido a partir do resíduo do despolpamento da fruta, com posterior desidratação (microencapsulação) por spray dryer, utilizando maltodextrina como agente carreador. A caracterização foi efetuada por determinação do teor de antocianinas e identificação destas por cromatografia líquida de alta eficiência (CLAE) e espectrometria de massas (MS), determinação da sua capacidade antioxidante pelos métodos Folin-Ciocalteu, capacidade redutora do ferro no plasma (FRAP) e capacidade antioxidante pelo radical DPPH. As características físicas avaliadas no extrato aquoso foram o valor de $\mathrm{pH}$ e o teor de sólidos solúveis. O potencial antimicrobiano foi determinado pelo método da concentração inibitória mínima (CIM) sobre as bactérias Staphylococcus aureus, Escherichia coli e Salmonella Enteritidis. O extrato de jabuticaba microencapsulado (EJM) foi utilizado para a elaboração de linguiça frescal e mortadela em duas diferentes concentrações: 2 e $4 \%$ de EJM para a linguiça frescal e $2 \%$ para mortadela. A linguiça frescal (à base de carne suína) e a mortadela (à base de carne bovina e carne mecanicamente separada de frango) foram avaliadas quanto à estabilidade durante armazenamento refrigerado a $1 \pm 1$ e $4 \pm 1^{\circ} \mathrm{C}$, por 15 e 56 dias, respectivamente. Os produtos foram caracterizados quanto à composição centesimal e foram realizadas análises físico-químicas, microbiológicas e sensoriais. Os resultados encontrados para a linguiça frescal confirmaram que o uso de $2 \%$ e $4 \%$ de EJM contribuíram para reduzir a oxidação lipídica durante os 15 dias de armazenamento e nas análises microbiológicas o EJM contribuiu para reduzir a contagem de microrganismos por 
quatro dias quando comparado com a linguiça controle (sem adição de EJM). A análise sensorial comprovou que $2 \%$ de EJM não comprometeu a maioria dos atributos sensoriais avaliados, com exceção da coloração mais escura. Recomendase, portanto, a utilização de $2 \%$ de EJM na produção de linguiça frescal. Nas mortadelas, os resultados não diferiram quando se comparou os produtos com $2 \%$ de EJM e sem adição do extrato (controle), porém, a utilização de $2 \%$ de EJM pode ser considerada uma alternativa interessante devido as demandas atuais por novas fontes de baixo custo e a utilização de pigmentos naturais que possam ser benéficos à saúde. Com estes resultados, pode-se dizer que o aproveitamento de cascas de jabuticaba oriundos do processamento da fruta, na forma de extrato microencapsulado, pode representar uma boa alternativa como corante natural, trazendo uma nova concepção da utilização de produtos mais saudáveis em linguiça frescal e mortadela.

Palavras chave: antocianinas, corantes, deterioração microbiana, embutidos, estabilidade, microbiologia. 


\begin{abstract}
BALDIN, J.C. Evaluation of antimicrobial and antioxidant potential of microencapsulated jabuticaba (Myrciaria cauliflora) extract added to fresh sausage and mortadella. 2016. 100f. Doctoral Thesis - Faculdade de Zootecnia e Engenharia de Alimentos (FZEA), Universidade de São Paulo, Pirassununga, 2016.
\end{abstract}

The objective of this study was to use jabuticaba extract microencapsulated as dye and evaluate its antimicrobial and antioxidant potential in fresh sausage and mortadella, replacing the traditionally used dye cochineal carmine. The first step was to evaluate in vitro antioxidant and antimicrobial properties of aqueous and microencapsulated jabuticaba extract. The extract was obtained from the the waste of fruit pulping, with subsequent dehydration (microencapsulation) by spray dryer using maltodextrin as carrier agent. The characterization was carried out by determining and identifying anthocyanins by high-performance liquid chromatography (CLAE) and mass spectrometry (MS), determining the antioxidant capacity by the Folin-Ciocalteu method, reducing capacity of iron in plasma (FRAP) and antioxidant activity by DPPH radical. Physical characteristics evaluated in the aqueous extract were $\mathrm{pH}$ value and soluble solids content. The antimicrobial potential was determined by the minimum inhibitory concentration (MIC) for the bacteria Staphylococcus aureus, Escherichia coli and Salmonella Enteritidis. Microencapsulated jabuticaba extract (MJE) was used for the preparation of fresh sausage and mortadella in two different concentrations: 2 and $4 \%$ EJM for fresh sausage and $2 \%$ for mortadella. The fresh sausage (pork) and mortadella (beef and mechanically separated meat chicken) were evaluated for stability during refrigerated storage at $1 \pm 1$ and $4 \pm 1^{\circ} \mathrm{C}$ for 15 and 56 days, respectively. The products were characterized for centesimal composition and were carried out physical-chemical, microbiological and sensorial analysis. The results for fresh sausage confirmed that the use of $2 \%$ and $4 \%$ EJM contributed to reduce lipid oxidation during the 15 days of storage and MJE contributed to reduce the microorganisms counts for four days when compared to the control sausage. Sensory analysis proved that $2 \%$ MJE did not compromise the majority of sensory attributes evaluated, but the darker color. It is recommended, therefore, the use of $2 \%$ MJE for producing fresh sausages. Regarding mortadella, the results did not differ when compared $2 \%$ EJM 
and control, attesting that the 2\% EJM can be considered an interesting alternative because of the current demands for new low-cost sources and using natural pigments, what can be beneficial to health. Considering the results, it can be state that the use of jabuticaba peel from fruit processing as microencapsulated extract can represent a good alternative as a natural dye, bringing a new conception of healthier products in fresh sausage and mortadella.

Keywords: anthocyanins, dye, meat products, microbiology, microbial deterioration, stability. 


\section{LISTA DE ILUSTRAÇÕES}

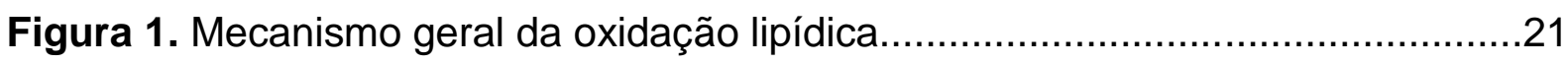

Figura 2. Estrutura fenólica dos antioxidantes sintéticos.......................................24

Figura 3. Estrutura química dos flavonóides.......................................................25

Figura 4. Estrutura básica das antocianidinas.....................................................33

Figura 5. Fluxograma para obtenção da casca e semente da jabuticaba..................39

Figura 6. Processo de obtenção do extrato da casca da jabuticaba........................40

Figura 7. Fluxograma para a obtenção do extrato concentrado da casca da

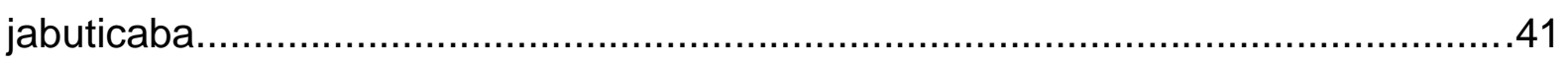

Figura 8. Extração do pigmento da casca da jabuticaba......................................42

Figura 9. Processo de microencapsulação do extrato de jabuticaba..........................43

Figura 10. Ficha utilizada para avaliação das amostras de linguiça frescal................58

Figura 11: Ficha utilizada para avaliação das amostras de mortadela........................58

Figura 12. Cromatograma do extrato obtido da casca da jabuticaba.........................62

Figura 13. Índice de TBARS ao longo da estocagem refrigerada da linguiça frescal.

Figura 14. Valores de $\mathrm{pH}$ ao longo da estocagem refrigerada da linguiça frescal.......70

Figura 15. Valores de $L^{*}$ ao longo da estocagem refrigerada da linguiça frescal........71

Figura 16. Valores de $\mathrm{a}^{*}$ ao longo da estocagem refrigerada da linguiça frescal........72

Figura 17. Tratamentos de linguiça frescal.....................................................

Figura 18. Valores de $b^{*}$ ao longo da estocagem refrigerada da linguiça frescal........73

Figura 19. Valores de $L^{*}$ ao longo da estocagem refrigerada da mortadela.................80

Figura 20. Valores de $\mathrm{a}^{*}$ ao longo da estocagem refrigerada da mortadela................81

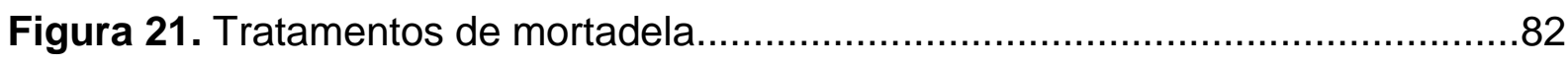

Figura 22. Avaliação sensorial do atributo aroma da mortadela ao longo da estocagem refrigerada.

Figura 23. Avaliação sensorial do atributo textura da mortadela ao longo da estocagem refrigerada

Figura 24. Avaliação sensorial do atributo sabor da mortadela ao longo da estocagem refrigerada.

Figura 25. Avaliação sensorial do atributo qualidade global da mortadela ao longo da estocagem refrigerada 


\section{LISTA DE TABELAS}

Tabela 1. Composição dos diferentes tratamentos para linguiça frescal..................49

Tabela 2. Composição dos diferentes tratamentos para mortadela...........................51

Tabela 3. Características cromatográficas e espectrométricas de antocianinas do

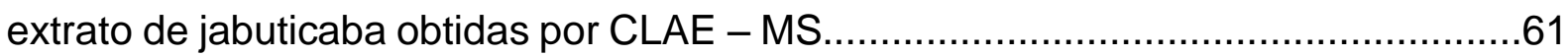

Tabela 4. Potencial antimicrobiano do extrato de jabuticaba aquoso sobre os

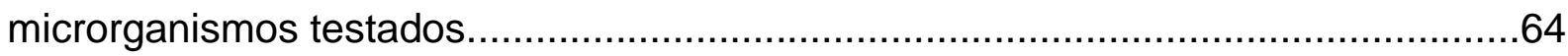

Tabela 5. Potencial antimicrobiano do extrato de jabuticaba microencapsulado sobre os microrganismos testados. 65

Tabela 6. Composição centesimal (\%) das amostras de linguiça frescal. .67

Tabela 7. Características microbiológicas ( $\log \mathrm{UFC} . \mathrm{g}^{-1}$ ) das linguiças frescais durante armazenamento refrigerado. .76

Tabela 8. Aceitação sensorial das linguiças frescais. . .77

Tabela 9. Composição centesimal (\%) das amostras de mortadela .78

Tabela 10. Características microbiológicas (Log UFC g ${ }^{-1}$ ) das mortadelas durante armazenamento refrigerado. 


\section{Sumário}

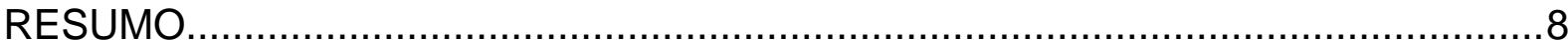

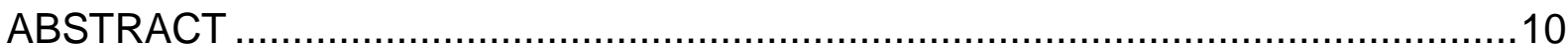

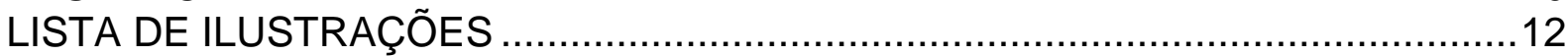

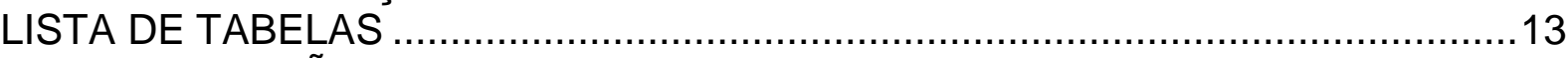

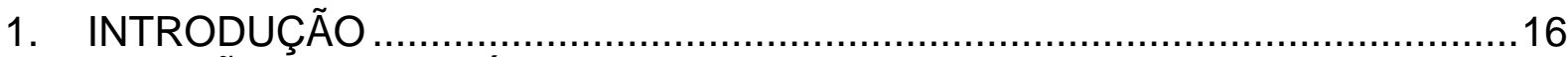

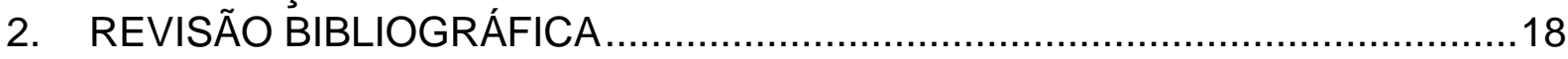

$2.1 \quad$ Embutidos cárneos............................................................................. 18

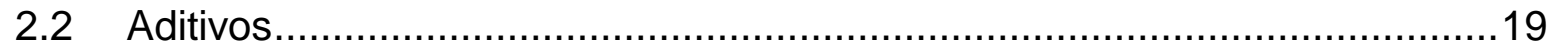

2.3 Importância dos lipídeos e processo de oxidação ...................................20

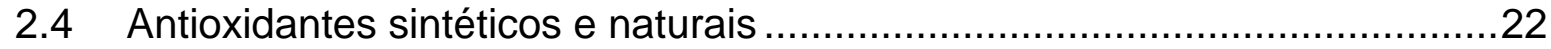

2.5 Aplicação dos antioxidantes em produtos cárneos ..................................26

2.6 Microbiologia da carne ..................................................................... 27

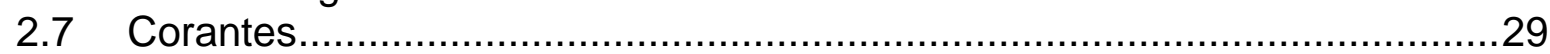

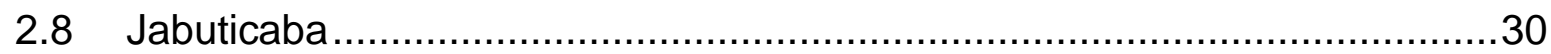

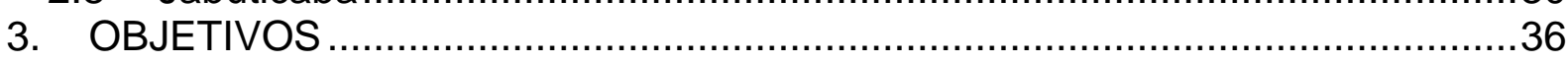

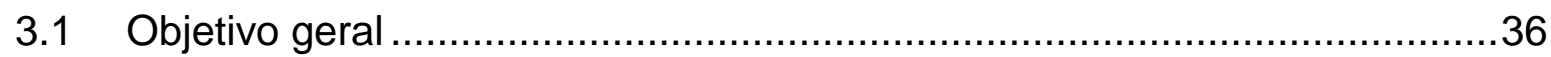

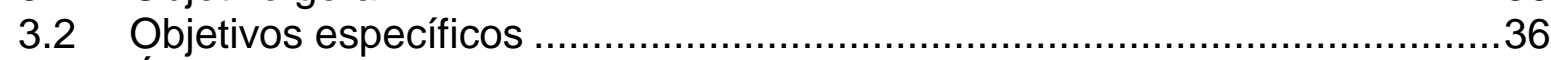

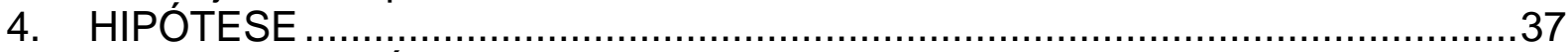

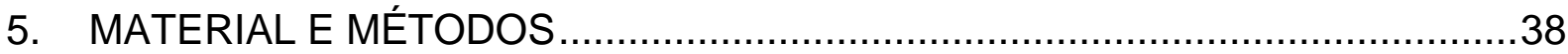

5.1 Obtenção do extrato de jabuticaba microencapsulado e determinação in vitro de seu potencial antioxidante e antimicrobiano .................................................38

5.1.1 Obtenção e microencapsulação do extrato aquoso de jabuticaba .........38

5.1.2 Determinação do teor de antocianinas totais ........................................44

5.1.3 Identificação das antocianinas por cromatografia líquida de alta eficiência

(CLAE), espectrometria de massas (MS) e quantificação por detector de

arranjos de diodos (DAD) .................................................................... 45

5.1 .4 Capacidade antioxidante in vitro .......................................................... 46

5.1.5 Atividade antimicrobiana in vitro..................................................... 47

5.2 Aplicação do extrato de jabuticaba microencapsulado em embutidos cárneos 49

5.2.1 Produção da linguiça frescal ........................................................49

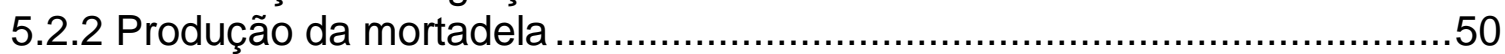

5.2.3 Composição centesimal da linguiça frescal e mortadela .........................51

5.2.4 Estabilidade físico-química dos embutidos .........................................53

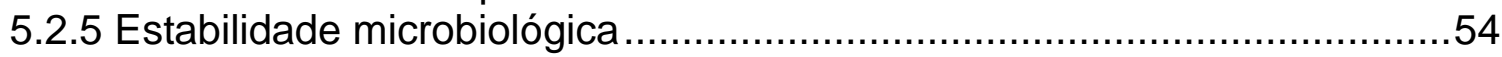

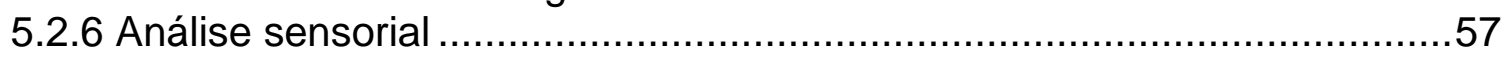

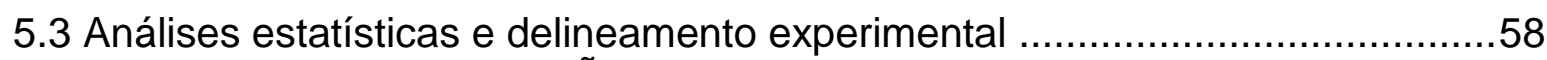

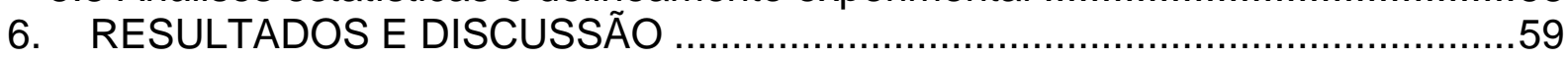

6.1 Caracterização e avaliação do potencial antioxidante e antimicrobiano do extrato aquoso e microencapsulado de jabuticaba .............................................59

6.1.1 Valor de $\mathrm{pH}$ e teor de sólidos solúveis do extrato aquoso ......................59

6.1.2 Teor de antocianinas totais do extrato de jabuticaba aquoso e microencapsulado

6.1.3 Análises do extrato de jabuticaba aquoso e microencapsulado por CLAE -

MS e quantificação por CLAE - DAD .......................................................61

6.1.4 Conteúdo fenólico e Capacidade antioxidante in vitro do extrato de jabuticaba aquoso e microencapsulado 
6.1.5 Avaliação in vitro do potencial antimicrobiano do extrato de jabuticaba aquoso e microencapsulado

6.2 Aplicação do extrato de jabuticaba microencapsulado em linguiça frescal......66

6.2.1 Composição centesimal da linguiça frescal............................................66

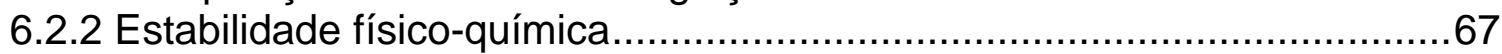

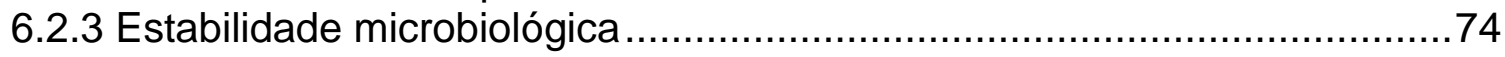

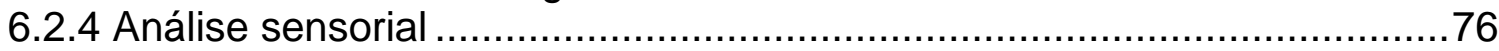

6.3 Aplicação do extrato de jabuticaba microencapsulado em mortadela ..............77

6.3.1 Composição centesimal da mortadela .................................................77

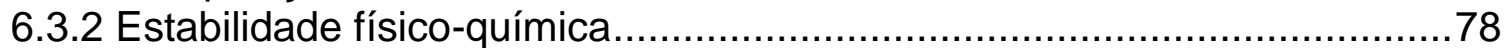

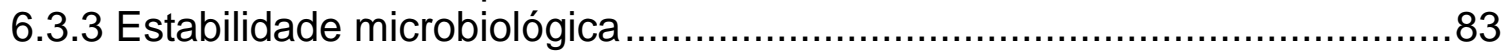

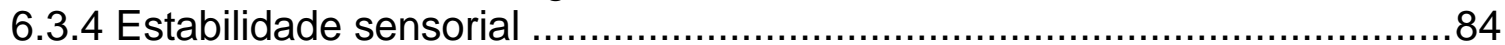

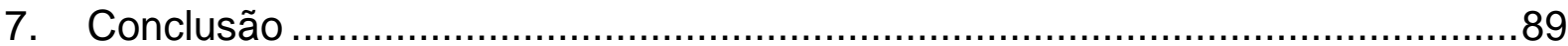

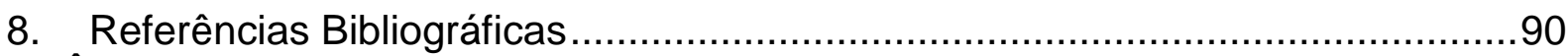

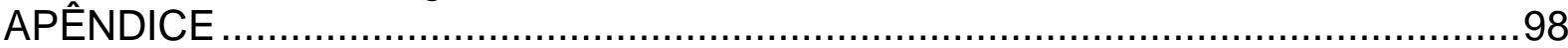




\section{INTRODUÇÃO}

A jabuticaba, fruto da jabuticabeira, pertencente à família Myrtaceae, é uma planta nativa do Brasil, a qual se estende por todo o país desde o Pará até o Rio Grande do Sul, com maior ocorrência e produtividade na região Sudeste. Do ponto de vista nutricional, a jabuticaba (Myrciaria cauliflora) apresenta boa quantidade de niacina, ferro e antocianinas em sua composição (DONADIO, 2000; CARVALHO et al, 2009). Dentre estes compostos, as antocianinas, flavonóides responsáveis pela sua coloração escura, estão presentes na casca da fruta. As moléculas das antocianinas são constituídas por duas ou três porções: uma aglicona (antocianidina), um grupo de açúcares e frequentemente, um grupo de ácidos orgânicos, sendo um dos seus maiores destaques o elevado potencial antioxidante e antimicrobiano (MALACRIDA; MOTTA, 2006). Devido à sua coloração atrativa, estes compostos são considerados como potenciais substitutos para os corantes sintéticos em diversos alimentos (BORDIGNON-LUIZ et al., 2007), podendo trazer ainda benefícios para a conservação destes alimentos devido ao seu potencial antioxidante e antimicrobiano. Para a utilização destes pigmentos naturais, o aproveitamento de resíduos (cascas e sementes) pode ser uma ótima fonte, sendo que estes são descartados das indústrias de geleias e licores de jabuticaba e representam, aproximadamente, $50 \%$ da fruta (PEREIRA et al., 2000; OLIVEIRA et al., 2003).

No que diz respeito aos produtos cárneos, um dos maiores problemas decorrentes do processamento e armazenamento da carne e seus derivados é a oxidação lipídica, cujo efeito é a diminuição da qualidade e da segurança dos produtos alimentares, afetando negativamente a cor, sabor, textura e os valores nutricionais do produto (MIELNIK et al., 2008). Nos derivados cárneos é necessária a utilização de conservantes, geralmente sintéticos, para controle das oxidações e aumento da vida útil, devido à cominuição das carnes, aumento da área exposta e presença natural de microrganismos. Entretanto, alguns conservantes podem também ser cancerígenos, como o nitrito de sódio e o antioxidante butil-hidroxi-tolueno (BHT). Consequentemente, várias pesquisas vêm sendo desenvolvidas para diminuir ou até mesmo substituir os conservantes sintéticos pelos naturais (BREWER, 2011; ALMEIDA et al., 2015; LEMOS, 2015), desta maneira priorizando a utilização de extratos de plantas, folhas e até mesmo casca de frutas como conservadores, visto que a capacidade que as cascas possuem de proteger o fruto in natura, com 
destaques para suas propriedades antioxidantes e antimicrobianas, também pode servir para proteger os alimentos processados. As frutas e os vegetais são ótimas fontes de busca para novos compostos antimicrobianos, sendo que a diversidade molecular destes produtos é muito superior àquela derivada dos processos de síntese química (NOVAIS et al., 2003; LÓPEZ-MALO; ALZAMORA; PALOU, 2004).

Desta forma, esta pesquisa se justifica pelo fato dos consumidores atualmente estarem buscando por produtos mais saudáveis e que façam uso de menores quantidades de conservantes sintéticos. Neste propósito, a aplicação do extrato de casca de jabuticaba, extraído somente com água e microencapsulado com maltodextrina, em linguiça frescal e mortadela com a função de corante natural, mas também apresentando atividades antioxidante e antimicrobiana, pode representar uma melhor utilização para este resíduo e ainda atender ao consumidor interessado em alimentos mais saudáveis. 


\section{REVISÃO BIBLIOGRÁFICA}

\subsection{Embutidos cárneos}

Desde a antiguidade, mesmo o homem não conhecendo os microrganismos, já se tinha conhecimento sobre a deterioração dos alimentos se não consumidos imediatamente. Uma das maneiras de se evitar tal problema foi ampliar sua vida útil, por meio da mistura de sal, ervas aromáticas, dessecação e embutimento da carne picada, o qual proporcionava um produto com sabor mais agradável, e desta maneira começava a preparação dos embutidos cárneos. A elaboração de embutidos iniciouse aproximadamente 1.500 a.C., sendo oriundos da região mediterrânea com clima favorável para sua maturação (ORDÓÑEZ et al., 2005a).

Definem-se derivados cárneos como produtos preparados com carnes, miúdos ou gorduras e subprodutos comestíveis provenientes de animais de abate, adicionados de condimentos, especiarias e aditivos autorizados. A qualidade de um produto cárneo pode ser influenciada pela seleção de matérias-primas e ingredientes para que não ocorra prejuízo nas etapas de processamento, garantindo a qualidade do produto final (ALENCAR, 1994; ORDÓÑEZ et al., 2005a).

A carne é rica em nutrientes e sempre foi desejada pelo homem. O ser humano pré-histórico se tornou caçador, obtendo assim a carne, porém, devido a sua perecibilidade era necessário o consumo imediato. Para contornar este problema foram desenvolvidas tecnologias de conservação, tais como salga, defumação e desidratação, as quais foram aperfeiçoadas pelo tempo com funções eficientes na prevenção do desenvolvimento microbiano e na deterioração da carne (PORTO, 2006).

As baixas temperaturas empregadas desde os primórdios eram restritas apenas às regiões frias e durante o inverno os homens pré-históricos conservavam a caça no meio do gelo para comê-las em seguida, e, no século VIII a.C., os chineses guardavam o gelo em covas para utilizá-lo no verão. Uma das grandes invenções da tecnologia de alimentos, iniciadas no século XIX, foi a produção contínua de frio, permitindo assim o armazenamento e transporte dos alimentos perecíveis, prolongando também sua vida útil (ORDÓÑEZ et al., 2005b; PORTO, 2006).

Os principais objetivos da industrialização da carne são aumentar sua vida útil, desenvolver sabores diferenciados e aproveitar partes da carcaça do animal que 
dificilmente seriam comercializadas in natura. Devido ao elevado valor nutricional e grande quantidade de água disponível nas carnes, essas são alvos fáceis dos microrganismos deteriorantes e patogênicos, tornando necessário o emprego de aditivos, calor, frio e a utilização de boas práticas de fabricação para que se obtenha derivados cárneos inócuos para os consumidores (TERRA, 1998).

Dentre os produtos cárneos conhecidos, foram escolhidos para o presente trabalho um embutido cru (linguiça frescal) e um embutido cozido (mortadela).

A linguiça frescal é um produto cárneo industrializado obtido de carnes de animais de açougue, adicionados ou não de tecidos adiposos, ingredientes, embutido em envoltório natural ou artificial e submetido ao processo tecnológico adequado. Apresenta como características físico-químicas: umidade máxima de $70 \%$, gordura máxima de 30\%, proteína mínima de 12\% e cálcio máximo de 0,1\% (BRASIL, 2000).

O embutido tipo mortadela é um produto cárneo industrializado, obtido de uma emulsão de carnes de animais de açougue, acrescido ou não de toucinho, adicionado de ingredientes, embutido em envoltório natural ou artificial, em diferentes formas, e submetido ao tratamento térmico adequado. Apresenta como características físicoquímicas: umidade máxima de $65 \%$, gordura máxima de 30\%, proteína mínima de $12 \%$, máximo de $10 \%$ de carboidratos totais (dos quais, no máximo $5 \%$ de amido) e máximo de 60\% de CMS (carne mecanicamente separada) (BRASIL, 2000).

\subsection{Aditivos}

As substâncias químicas são usadas nos alimentos com o objetivo de conservá-los desde os tempos da pré-história, época em que o homem descobriu o fogo e criou o processo de defumação, utilizado até hoje na preparação de carnes e peixes, possuindo como principal desígnio atribuir características específicas e desejáveis de cor, aroma e sabor. O sal também foi descoberto como uma substância hábil na conservação de carnes, e a utilização de condimentos e especiarias aprimorava a palatabilidade de alimentos, principalmente dos processados. Atualmente, com avanços tecnológicos nas indústrias há disponibilidade de substâncias que têm capacidade de melhorar a cor, aroma, textura e sabor. Segundo normas brasileiras, a definição de aditivos consiste em uma substância intencionalmente adicionada ao alimento, com a finalidade de conservar, intensificar 
ou modificar suas propriedades, desde que não prejudique seu valor nutricional (MARQUES, 1994).

A utilização de aditivos pode ser importante para proteção da matéria-prima, produção, segurança e melhoria dos produtos, tornando-os atraentes para o consumidor; contribuindo para o aumento da vida de prateleira, transporte e armazenamento dos produtos; possibilitando que os produtos permaneçam no mercado com maior frequência, com grande variedade e em todas as épocas. Desta forma, os aditivos precisam atender alguns requisitos para o seu emprego nos alimentos: ser necessário à tecnologia de fabricação, ser registrado no órgão competente, ser utilizado em quantidades corretas, respeitar o limite máximo exigido, ser inócuo, preservar as características dos produtos, não reduzir os valores nutricionais dos alimentos e conservar o produto com maior vida útil (EVANGELISTA, 2001).

\subsection{Importância dos lipídeos e processo de oxidação}

A constituição dos lipídeos é uma mistura de tri, di e monoacilgliceróis, ácidos graxos livres, glicolipídios, fosfolipídios, esteróis e outras substâncias. A maioria é oxidável em diferentes graus, sendo que os ácidos graxos insaturados são os mais suscetíveis ao processo oxidativo (RAMALHO; JORGE, 2006).

Os lipídeos são predispostos às diversas alterações químicas durante 0 processamento, armazenamento e consumo de um alimento e as substâncias geradas podem ser desejáveis ou não ao flavor. Os lipídeos estão presentes em quase todos os alimentos e são, muitas vezes, insolúveis em água, entretanto, têm importância nutritiva, são veículos de vitaminas lipossolúveis, contribuem para melhorar o sabor e a sensação de saciedade após se alimentar, servem como isolante térmico e protegem os órgãos internos. No entanto, determinados alimentos são suscetíveis a fenômenos de deterioração (rancificação) provocando alterações nas suas características sensoriais (ORDÓÑEZ et al., 2005b; ARAÚJO, 2011).

A oxidação é um fenômeno natural que ocorre em alimentos e é responsável por várias alterações, levando à perda de valor nutricional, mudanças das características sensoriais, rejeição do produto e, eventualmente, formação de compostos tóxicos nos alimentos. Nos lipídeos, as alterações sensoriais envolvem o desenvolvimento de aromas desagradáveis (ranço). Os efeitos da oxidação afetam a 
maioria dos componentes no alimento, incluindo os micronutrientes (cor, flavor, vitaminas e minerais) e os macroconstituintes (carboidratos, lipídeos e proteínas). $\mathrm{Na}$ oxidação de lipídeos, diversas reações de decomposição ocorrem concomitantemente, formando misturas complexas de produtos (aldeídos, cetonas, álcoois e hidrocarbonetos), os quais são voláteis, contribuindo para o odor característico associado à oxidação lipídica (ARAÚJO, 2011).

Segundo Ramalho e Jorge (2006), há diversas maneiras de ocorrer a oxidação lipídica: por reações hidrolíticas, oxidação enzimática, fotoxidação e autoxidação. A autoxidação é o principal mecanismo de oxidação de óleos e gorduras e está associada à reação do oxigênio com ácidos graxos insaturados e acontece em três etapas: iniciação, propagação e término (Figura 1).

Figura 1. Mecanismo geral da oxidação lipídica.

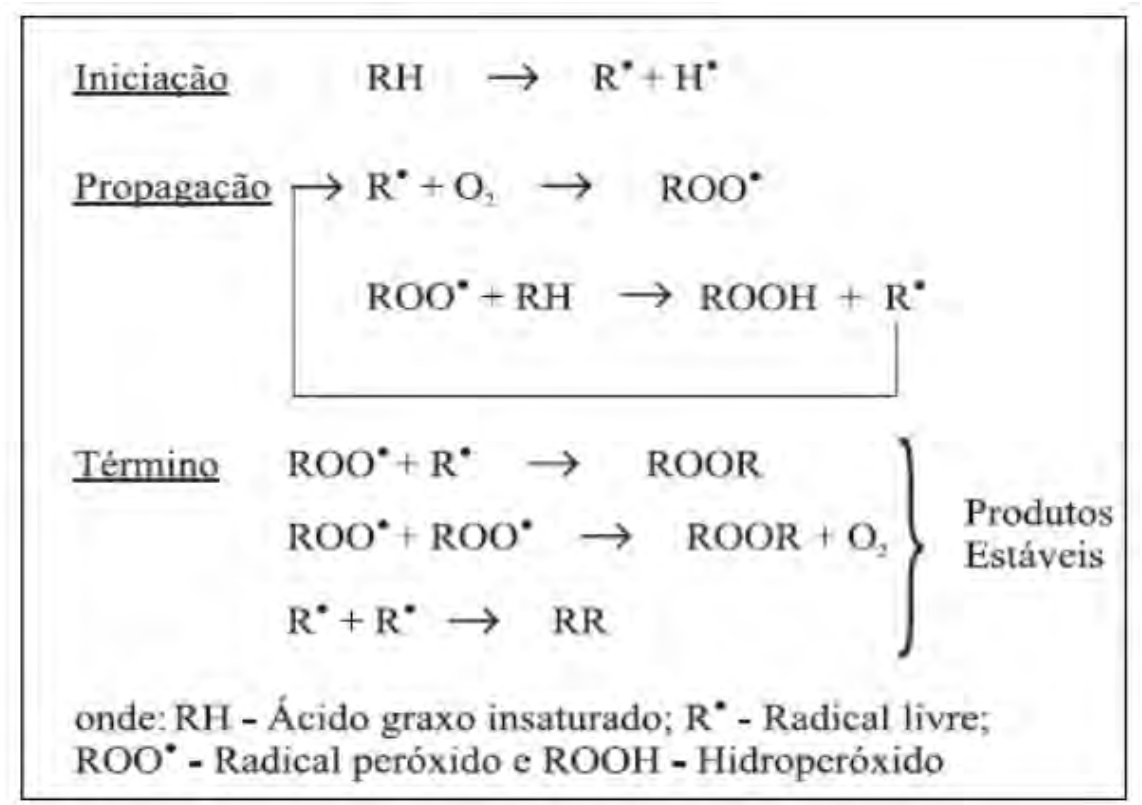

Fonte: RAMALHO, V. C.; JORGE, N. Antioxidantes utilizados em óleos, gorduras e alimentos gordurosos. Química Nova, São Paulo, v. 29, n. 4, p. 755-760, 2006.

A fase de iniciação ocorre com a retirada de um átomo de hidrogênio da molécula de ácido graxo $(\mathrm{RH})$, por meio de temperaturas altas e catalisadores (como luz e alguns metais), formando um radical livre $(R \bullet)$. Quanto maior o número de duplas ligações em um ácido graxo mais simples é a remoção do hidrogênio, devido a isto, os ácidos graxos insaturados são mais suscetíveis à oxidação (ORDÓÑEZ et al., 2005b; RAMALHO; JORGE, 2006). 
$\mathrm{Na}$ fase de propagação, os radicais livres formados reagem com o oxigênio atmosférico $\left(\mathrm{O}_{2}\right)$ e são convertidos em produtos primários de oxidação formando um radical peróxido (ROO•), esses podem retirar hidrogênio de outra molécula insaturada $(\mathrm{RH})$ podendo formar os hidroperóxidos $(\mathrm{ROOH})$ e também outro radical livre $(\mathrm{R} \cdot)$. Essa reação pode ocorrer várias vezes e sua natureza é de reação em cadeia (ORDÓÑEZ et al., 2005b; RAMALHO; JORGE, 2006).

$\mathrm{Na}$ fase de término dois radicais se combinam, com a formação de produtos estáveis não-reativos (produtos secundários de oxidação), neste momento se não houver mais radicais livres que reajam com o oxigênio o processo está concluído, e se torna necessário produzir uma nova reação de iniciação para que continue o processo oxidativo (ORDÓÑEZ et al., 2005b; RAMALHO; JORGE, 2006).

Alguns dos fatores que influenciam diretamente na velocidade da reação química e beneficiam a oxidação lipídica são a quantidade de oxigênio presente no alimento (sendo necessário utilizar embalagens à vácuo), composição da gordura (o grau de instauração e o tipo de ácido graxo insaturado influencia na reação), exposição à luz (evitar incidência de luz direta nos alimentos expostos nos balcões refrigerados), temperatura de armazenamento (não deixar alimentos refrigerados em temperaturas ambientes e nem congelados por tempo excessivo), atividade de água (produtos com alta atividade de água têm maior propensão à oxidação) e presença de pró-oxidantes (metais, grupos heme das moléculas de mioglobina e enzimas como as lipo-oxidases podem agir como catalisadores das reações) (ORDÓÑEZ et al., 2005b).

\subsection{Antioxidantes sintéticos e naturais}

Segundo Brewer (2011), diversos ingredientes alimentares que contêm ácidos graxos insaturados são suscetíveis à deterioração, especialmente sob estresse oxidativo. Por esta razão, os esforços para reduzir a oxidação têm aumentado e, na maioria das vezes, a melhor estratégia é a utilização de antioxidantes.

Os antioxidantes são empregados com a finalidade de inibir ou retardar a oxidação lipídica de óleos, gorduras e alimentos gordurosos. São substâncias presentes de forma natural ou intencionalmente adicionadas aos alimentos com a finalidade de retardar o aparecimento dos fenômenos da oxidação, desde que mantenham ilesas as características sensoriais. Para a escolha dos antioxidantes a serem adicionados em alimentos, são desejáveis algumas propriedades: ser eficaz 
em baixas concentrações, não apresentar efeitos indesejáveis na cor, odor, sabor e em outras características do produto, ser compatível com o alimento, ser de fácil aplicação, ser estável quanto às condições de processo e armazenamento, não apresentar toxicidade, respeitar a legislação vigente, ter baixo custo, não causar efeitos fisiológicos negativos, ser eficaz em baixas temperaturas, de fácil obtenção, econômicos e respeitar a preferência dos consumidores por produtos naturais (ORDÓÑEZ et al., 2005b; RAMALHO; JORGE, 2006).

Os antioxidantes são compostos ou sistemas que retardam a autoxidação por inibição da formação de radicais livres ou por interrupção da propagação dos mesmos por meio de um ou mais mecanismos: eliminação da espécie que iniciou a peroxidação, quelação de íons metálicos, inibição de oxigênio singlete, prevenindo a formação de peróxidos, quebrando a reação em cadeia da autoxidação e reduzindo a concentração de oxigênio. Os mais eficazes são aqueles que interrompem a reação em cadeia de radicais livres, os quais geralmente contêm anéis aromáticos ou fenólicos e doam hidrogênio para os radicais livres formados durante a oxidação, tornando-se um radical estável (BREWER, 2011).

Os antioxidantes têm sido tradicionalmente divididos em duas classes: primários ou de quebra de cadeia, e secundários ou preventivos. Os primários interrompem a cadeia de reação pela doação de elétrons ou hidrogênio aos radicais livres, formando compostos estáveis. Os secundários retardam a etapa de iniciação da autoxidação, por diferentes mecanismos que incluem complexação de metais, sequestro de oxigênio, decomposição de hidroperóxidos para formar espécie não radical, absorção da radiação ultra-violeta (UV) ou desativação de oxigênio singlete (ANGELO; JORGE, 2007; APAK, 2007).

Os antioxidantes podem ser classificados, quanto a sua origem, em sintéticos e naturais. Os sintéticos mais utilizados em alimentos são o butil-hidroxi-anisol (BHA), butil-hidroxi-tolueno (BHT), terc-butil-hidroquinona (TBHQ) e propil galato (PG), e estão apresentados na Figura 2. Nestas estruturas fenólicas, permite-se a doação de um próton a um radical livre, interrompendo o mecanismo de oxidação pelos radicais livres. Várias pesquisas vêm sendo realizadas para substituição desses antioxidantes sintéticos pelos naturais devido aos problemas relacionados ao consumo de antioxidantes sintéticos, tais como possibilidade de efeito carcinogênico em animais (RAMALHO; JORGE, 2006). 
Figura 2. Estrutura fenólica dos antioxidantes (sintéticos).

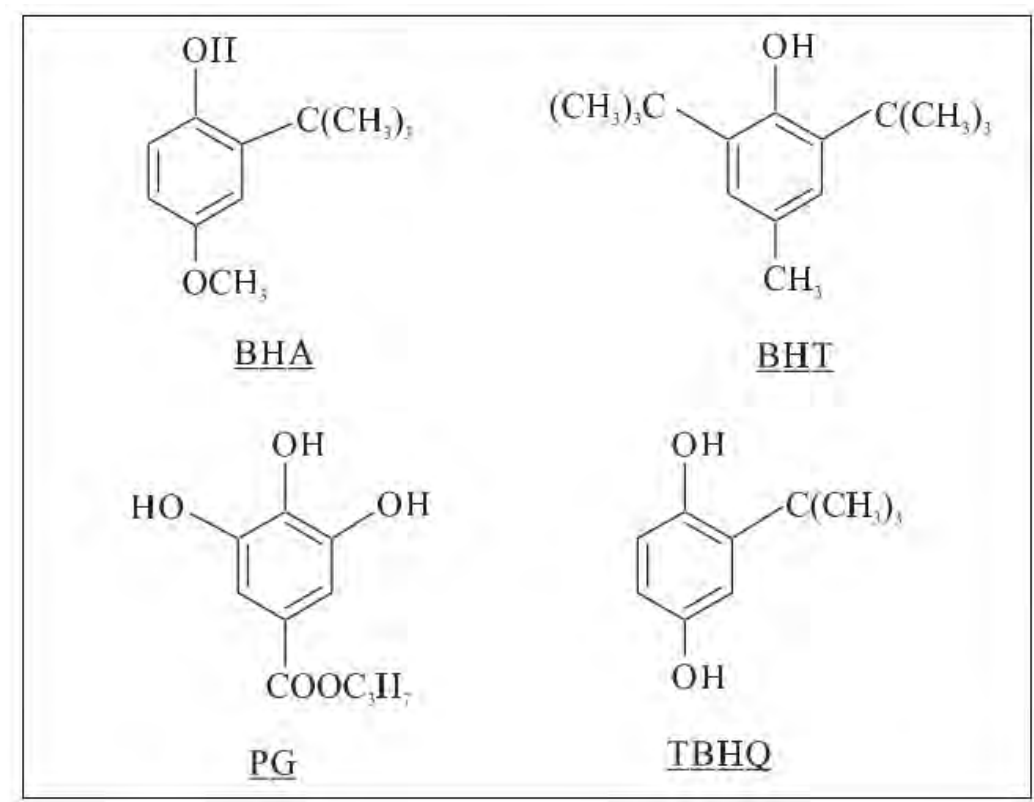

BHA: butil-hidroxi-anisol; BHT: butil-hidroxi-tolueno; PG: propil galato; TBHQ: terc-butilhidroquinona.

Fonte: RAMALHO, V. C.; JORGE, N. Antioxidantes utilizados em óleos, gorduras e alimentos gordurosos. Química Nova, São Paulo, v. 29, n. 4, p. 755-760, 2006.

De acordo com Ramalho e Jorge (2006), os tocoferóis, ácidos fenólicos e extratos de plantas, como alecrim e sálvia, estão entre os antioxidantes naturais mais usados. Os antioxidantes fenólicos são sequestradores de radicais e quelantes de metais, agindo na etapa de iniciação e de propagação do processo oxidativo e os produtos intermediários formados são estáveis.

O uso de plantas como fonte de antioxidantes para melhorar as propriedades dos alimentos, com fins nutricionais e preservação, é de grande interesse. Diversos estudos demonstraram uma relação inversa entre o consumo de frutas, legumes e cereais e a incidência de doença cardíaca coronária e câncer. Alguns dos componentes da dieta que contribuem para esta proteção são as vitaminas $\mathrm{C}$ e $\mathrm{E}$, selênio e outros micronutrientes minerais, carotenoides, fitoestrogênios e ácido fólico. Esses compostos podem atuar independente ou em combinação como agentes cardioprotetores ou anticancerígenos por vários mecanismos: no caso das vitaminas $\mathrm{C}$ e $\mathrm{E}$ e os carotenoides a atividade antioxidante é pela eliminação dos radicais livres formados, havendo também destaque para o papel de componentes fitoquímicos: flavonóides e ácidos fenólicos como fatores importantes que contribuem para a atividade antioxidante da dieta (RICE-EVANS; MILLER; PAGANGA, 1997). 
Os flavonóides são uma grande classe de compostos, presentes nas plantas, que apresentam uma estrutura química composta por dois anéis aromáticos $\mathrm{A}$ e $\mathrm{B}$ e um anel heterocíclico, unidos por três átomos de carbono e uma mólecula de oxigênio (ANGELO; JORGE, 2007; APAK et al. 2007), apresentados na Figura 3.

Figura 3. Estrutura química dos flavonóides.

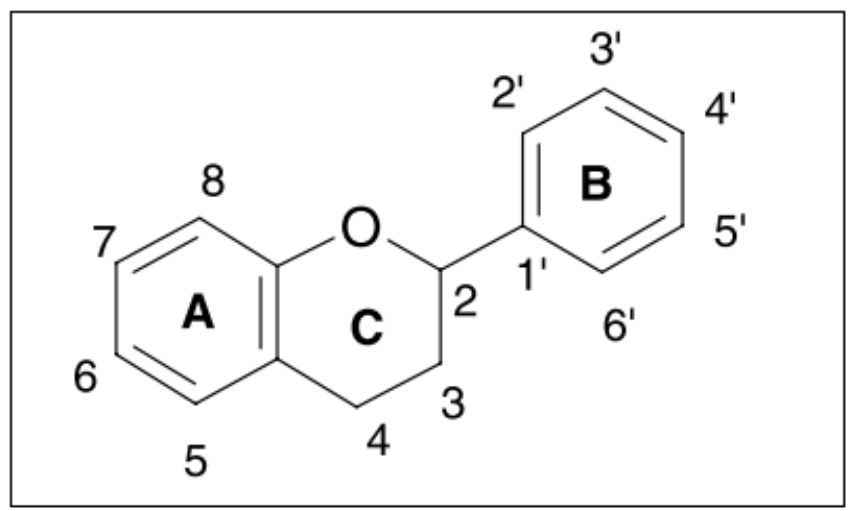

Fonte: BALASUNDRAM, N.; SUNDRAM, K.; SAMMAN, S. Phenolic compounds in plants and agriindustrial by-products: Antioxidant activity, occurrence, and potential uses. Food Chemistry, Amsterdam, v. 99, p. 191-203, 2006.

Nas plantas, o maior grupo de fitoquímicos existentes são os compostos fenólicos, como fenóis simples, cumarinas, ácidos fenólicos, flavonóides e taninos. Dentre os compostos fenólicos que merecem destaque por serem mais conhecidos e pesquisados, estão os ácidos fenólicos, os flavonóides e os polifenóis (KING; YOUNG, 1999; SOARES, 2002, DEGÁSPARI; WASZCZYNSKYJ, 2004; RAMALHO; JORGE, 2006).

As plantas são excelentes fontes de compostos fenólicos, os quais são metabólitos secundários com funções de pigmentação, adstringência, proteção contra raios UV e antioxidantes nos vegetais, e possuem propriedades fisiológicas nos humanos, como atividade anti-inflamatória, antimicrobiana, antitrombótica, cardioprotetora e vasodilatadora (RICE-EVANS; MILLER; PAGANGA, 1997; BALASUNDRAM; SUNDRAM; SAMMAN, 2006).

Os compostos fenólicos têm sua atividade antioxidante relacionada à capacidade em sequestrar radicais livres e quelar íons metálicos e podem atuar nas etapas de iniciação e propagação na reação de oxidação dos lipídeos, por meio da doação de hidrogênio e elétrons, e pela geração de radicais estáveis (SHAHIDI; WANASUNDARA, 1992; BRAND-WILLIAMS, CURVELIER e BERSET, 1995; RAMALHO; JORGE, 2006). 


\subsection{Aplicação dos antioxidantes em produtos cárneos}

Vários trabalhos têm sido realizados por pesquisadores interessados em produtos cárneos mais saudáveis. Pham et al. (2014) avaliaram os efeitos do alecrim e de extratos de chá verde na conservação da linguiça suína fresca em armazenamento congelado e verificaram efeitos significativos de ambos extratos de plantas em retardar a oxidação lipídica em todos os períodos estudados. Almeida et al. (2015) adicionaram extrato etanólico de casca de jabuticaba liofilizado nas concentrações zero (controle), 0,25, 0,5, 0,75 e 1,0\% em mortadela tipo bologna, armazenadas sob refrigeração por 35 dias, e concluíram que a adição do extrato teve efeito no $\mathrm{pH}$ e protegeu as amostras da mudança na cor durante estocagem, sendo que as amostras adicionadas de 0,5, 0,75 e 1\% de extrato apresentaram menores valores de TBARS (substâncias reativas ao ácido tiobarbitúrico) quando comparados ao controle, porém, não obtiveram efeito positivo na estabilidade microbiológica. A adição de até $0,5 \%$ de extrato não afetou a qualidade sensorial, mas preveniu a diminuição da aceitação sensorial durante estocagem. De acordo com os autores, o extrato de jabuticaba liofilizado pode ser utilizado em mortadela tipo bologna para melhorar a estabilidade oxidativa durante sua vida de prateleira.

Munekata et al. (2015) adicionaram extrato etanólico da pele de amendoim em hambúrgueres de frango cozidos e analisaram o efeito do extrato na cor e oxidação lipídica dos hambúrgueres por 15 dias armazenados sob refrigeração. As amostras com o extrato da pele de amendoim apresentaram maior valor de $\mathrm{a}^{*} \mathrm{e}$ menores valores de $L^{*}$ e $b^{*}$ quando comparados ao controle. Os resultados para oxidação lipídica no tratamento controle foi $19 \mathrm{mg}$ de malonaldeído/kg, enquanto no tratamento com extrato da pele de amendoim foi $0,97 \mathrm{mg}$ de malonaldeído/kg a partir do oitavo dia de armazenamento. Os autores concluíram que o extrato da pele de amendoim, embora tenha causado um ligeiro escurecimento da amostra (menor valor de $L^{*}$ ), apresentou maior valor de $a^{\star}$ e inibiu a oxidação lipídica dos hambúrgueres em todo o período de estocagem, sendo uma fonte natural de compostos fenólicos.

Stefanello et al. (2015) determinaram o efeito do extrato hidroetanólico de cogumelo do sol sobre a estabilidade oxidativa de linguiça de carne suína durante o armazenamento a $4^{\circ} \mathrm{C}$. Os resultados encontrados para 0 valor de TBARS (substâncias reativas ao ácido tiobarbitúrico) aos 21 dias para as linguiças com 2,0\% de extrato foram inferiores $(0,705 \pm 0,01 \mathrm{mg} \mathrm{MDA} / \mathrm{kg}$ de amostra) ao controle 
$(1,097 \pm 0,11 \mathrm{mg} \mathrm{MDA} / \mathrm{kg}$ de amostra). Os autores concluíram que o extrato hidroetanólico de cogumelo do sol foi efetivo sobre a estabilidade oxidativa de linguiça de carne suína quando adicionado na concentração de 2,0\%, estendendo a vida útil até 21 dias de estocagem a $4^{\circ} \mathrm{C}$, concluindo que a sua aplicação como antioxidante natural é viável, sendo os principais antioxidantes presentes nos cogumelos os compostos fenólicos.

\subsection{Microbiologia da carne}

O animal vivo é a principal fonte de microrganismos, e os locais com maior quantidade são a pele, o trato respiratório e o trato digestivo. Normalmente essa microbiota não causa problemas, pois está em equilíbrio com o animal. Porém, após - abate esse metabolismo cessa, e há possibilidades desses microrganismos invadirem o interior do animal, causando a contaminação da carcaça com possível deterioração da carne, tornando necessária uma rápida evisceração imediatamente após abate e boas práticas na manipulação destas carcaças (PORTO, 2006).

Dentre os microrganismos que podem crescer na carne e seus derivados, as bactérias são o grupo mais predominante e importante, devido à alta umidade e pH neutro do substrato. Os principais fatores que afetam o crescimento de microrganismos em produtos cárneos são: binômio tempo e temperatura, umidade, presença ou ausência de oxigênio, potencial óxido-redução, grau de acidez ou alcalinidade $(\mathrm{pH})$, propriedades físicas da carne e competição entre microrganismos (ROMANS et al., 2001).

No processamento de carnes, dois tipos de microrganismos estão envolvidos: os patogênicos e os deteriorantes. O primeiro grupo não é desejável e é necessário seu controle, no segundo grupo a sua presença é inevitável, mas o controle da população é geralmente eficaz (PORTO, 2006).

Segundo a resolução RDC n¹2/2001 (BRASIL, 2001), que estabelece os padrões microbiológicos em alimentos, para linguiça frescal o limite para Staphylococcus aureus e coliformes a $45^{\circ} \mathrm{C}$ é de $5 \times 10^{3} \mathrm{UFC}^{-1}$, e para clostrídios sulfito redutores a $46^{\circ} \mathrm{C}$ é de $3 \times 10^{3}$ UFC $g^{-1}$. Para mortadela, o limite para Staphylococcus aureus é de $3 \times 10^{3} \mathrm{UFC} \mathrm{g}^{-1}$, para coliformes a $45^{\circ} \mathrm{C}$ é de $10^{3} \mathrm{UFC}$ $\mathrm{g}^{-1}$ e para clostrídios sulfito redutores a $46^{\circ} \mathrm{C}$ é de $5 \times 10^{2} \mathrm{UFC} \mathrm{g}^{-1}$. Por outro lado, para 
ambos os embutidos é determinada a ausência em $25 \mathrm{~g}$ para Salmonella sp., devido a gravidade e alta mortalidade da doença causada por esse microrganismo.

O controle dos diferentes tipos de microrganismos é diferente devido às diversas características apresentadas. Para os deteriorantes, os objetivos de redução da contaminação dos produtos cárneos ou impedimento da proliferação bacteriana são alcançáveis por meio da utilização da cadeia de frio, embalagens à vácuo ou uso de antimicrobianos, os quais impedem sua multiplicação. Por outro lado, as bactérias patogênicas habitam normalmente os animais, tornando mais difícil seu controle se não tomadas as medidas higiênicas no abate e processamento destas carnes. Com isso, há diversos objetivos no controle de qualidade dessas bactérias: para as deteriorantes o ideal é diminuir sua contaminação no processo e evitar sua multiplicação, para as patogênicas é necessário impedir sua entrada no abate do animal e evitar a contaminação cruzada com carcaças contaminadas (PORTO, 2006).

Consequentemente, a satisfação dos consumidores ao adquirir um alimento sem contaminação é o objetivo final de todo processamento de derivados cárneos. Um produto seguro é aquele que apresenta uma diminuição ou restrição do crescimento de microrganismos (ROMANS et al., 2001). Neste propósito, o uso de antimicrobianos em alimentos processados torna-se necessário, reforçando o uso de antimicrobianos naturais oriundos das plantas e vegetais.

Diversas pesquisas têm sido desenvolvidas comprovando o potencial antimicrobiano in vitro de várias plantas e extratos, inibindo principalmente bactérias. Silva et al. (2007) avaliaram a ação antimicrobiana do extrato hidroalcóolico da casca do caule do cajueiro frente a amostras de Staphylococcus aureus resistentes e sensíveis à meticilina, as bactérias apresentaram sensibilidade à ação do extrato, demonstrando grande eficácia do cajueiro. Carvalho et al. (2009) utilizaram o extrato de folhas de jabuticabeira e verificaram atividade inibitória sobre Streptococcus mutans, Streptococcus sobrinus e Streptococcus sanguinis, evidenciando o potencial antimicrobiano dessa planta. Macedo-Costa et al. (2009) observaram atividade bacteriostática in vitro sobre bactérias do biofilme dental, gênero Streptococcus sp., também com a utilização do extrato das folhas de jabuticabeira. Martin et al. (2012) utilizaram extratos etanólicos e metanólicos de resíduos vegetais agro-industriais (bagaço de goiaba e de uva) e encontraram concentrações mínimas de inibição para Staphylococcus aureus e Listeria monocytogenes com a utilização do bagaço de uva. Demirdoven, Karabiyikli e Oncül (2015) investigaram as propriedades antimicrobianas 
de extratos de cereja azeda e de bagaço de repolho vermelho, observando que os extratos apresentaram efeitos antimicrobianos para Escherichia coli, Staphylococcus aureus, Listeria monocytogenes, Salmonella Typhimurium e Bacillus cereus, concluindo que os efeitos antimicrobianos dos extratos foram, principalmente, devido ao teor de antocianinas dos mesmos.

\subsection{Corantes}

A cor influencia de forma decisiva na preferência do consumidor ao adquirir um alimento, sendo de grande importância o desenvolvimento de produtos com aparência atrativa. O impacto visual causado pela cor, geralmente se sobrepõe ao causado pelos outros atributos (BARROS; STRINGHETA, 2006). Com este propósito, o desenvolvimento da indústria alimentícia levou à produção e consequente disponibilização de diferentes corantes sintéticos e naturais no mercado.

A utilização de corantes sintéticos (tartrazina, amarelo crepúsculo, ponceau 4R, vermelho 40, Bordeaux $S$, eritrosina e indigotina) na indústria alimentícia é permitida pela legislação brasileira. Contudo, com a crescente preocupação pública sobre a segurança desses corantes, os extratos de pigmentos naturais estão assumindo maiores destaques e os mais empregados na indústria alimentícia são os extratos de urucum, carmim de cochonilha, curcumina, betalaínas e antocianinas (BRIDLE; TIMBERLAKE, 1997; SILVA et al., 2010a).

As pesquisas com a utilização dos corantes naturais têm ganhado merecido destaque e apresentam extensa e ativa área de investigação, devido ao crescente interesse na substituição dos corantes sintéticos, os quais podem apresentar efeitos tóxicos e desencadear doenças nos indivíduos (CHOU et al., 2007).

Os corantes naturais mais usados nas indústrias são os carotenoides e as antocianinas. Os carotenoides são compostos lipofílicos, solúveis em óleos e solventes orgânicos, sofrem oxidação na presença de ar e luz e são responsáveis pelas cores amarelo, laranja e vermelho presentes em frutas, legumes, gema de ovo, crustáceos e alguns peixes, sendo oriundos de cenouras, tomates e pimentas. As antocianinas, objetos do presente estudo, são solúveis em água, menos estáveis que os carotenoides e são obtidas da uva, morango, cereja, jabuticaba, entre outros produtos de coloração escura. Esses pigmentos são responsáveis pelas cores rosa, 
vermelho, violeta e azul presentes nas flores e frutas (CASTAÑEDA-OVANDO et al, 2009; FENNEMA; DAMODARAN; PARKIN, 2010).

O carmim de cochonilha tem sido utilizado na produção de derivados cárneos para obtenção da coloração rosada nas massas de embutidos e pode ser considerado um aditivo saudável e de boa qualidade (BLOUKAS; ARVANITOYANNIS; SIOPI, 1999). No entanto, tem sido alvo de muitas críticas por alguns consumidores que não consideram adequado o consumo de um corante proveniente de um inseto. A cochonilha é um inseto parasitário originário do México e está presente nas folhas, frutos, ramos e raízes das plantas. A espécie utilizada para preparo do corante é Dactylopius coccus, mede de 2 a $5 \mathrm{~mm}$ de comprimento e produz o ácido carmínico, sendo que esse ácido é extraído do corpo e dos ovos do inseto e usado nas indústrias cosméticas e alimentícias. Na produção do carmim de cochonilha são necessários 70.000 insetos esmagados e fervidos para produzir aproximadamente meio quilo do corante. São criados e destruídos todos os anos bilhões de insetos utilizados para dar cor a biscoitos e leites de soja sabor morango, sorvetes de frutas vermelhas e embutidos cárneos (CEREGATTI, 2012; CHAVES, 2012; VOCÊ CONHECE..., 2012; MARTINEZ, 2016). Assim, a utilização de outros corantes naturais, como as antocianinas, poderia substituir o carmim de cochonilha, não apenas com a finalidade de coloração do alimento, como também com ação antioxidante e antimicrobiana.

\subsection{Jabuticaba}

Os consumidores estão cada vez mais interessados em produtos que forneçam não somente os nutrientes essenciais para a manutenção da vida, bem como o consumo de alimentos que promovam benefícios à saúde e possuam a capacidade de reduzir o risco de desenvolver doenças crônicas não transmissíveis. Tal efeito se deve, em grande parte, às propriedades biológicas chamadas promotoras da saúde, dentre elas: atividades antioxidantes, anti-inflamatórias e hipocolesterolêmicas de nutrientes como as vitaminas e compostos fenólicos, como os flavonóides. Alguns exemplos são as catequinas do chá verde e do vinho, os flavonóis das folhas e as isoflavonas da soja e as antocianinas dos frutos vermelhos (RICE-EVANS; MILLER; PAGANGA, 1996; SEIFRIED et al., 2007).

Nesta busca por produtos saudáveis, as frutas vêm ganhando cada vez mais espaço na mesa do consumidor e são incorporadas em sucos, geleias, doces, saladas 
e inclusive como suplementos vitamínicos. Nesse contexto, a jabuticaba, fruto da jabuticabeira, tem sido cada vez mais valorizada, por ser uma fruta nativa do Brasil e apresentar diversas variedades. Uma das formas de consumo da jabuticaba é in natura ou processada na forma de sucos, geleias ou licores. Por ser uma fruta extremamente perecível, com um pequeno período de comercialização, de até três dias após sua colheita, recomenda-se sua utilização na forma de polpa congelada com o objetivo de aumentar sua vida de prateleira. Esse curto período de comercialização deve-se a alteração na aparência decorrente principalmente, da perda de umidade, deterioração e fermentação da polpa, o que ocorre principalmente pelo seu elevado teor de água e açúcares (ASCHERI; ASCHERI; CARVALHO, 2006; SATO; CUNHA, 2009; NUNES et al., 2014).

A jabuticaba apresenta aproximadamente $315 \mathrm{mg}$ de antocianinas por $100 \mathrm{~g}$ da fruta, valor considerado elevado quando comparado com outras frutas como jambolão (378 a 386 mg/100g), amora (261 a 292 mg/100g) e uva (227 a 235 mg/100g) (TERCl, 2004). A jabuticaba também é uma fonte considerável de carboidratos, fibras alimentares, vitaminas e sais minerais como ferro, cálcio e fósforo, e desperta interesse pela quantidade de compostos fenólicos com potencial antioxidante e antimicrobiano (DONADIO, 2000; ASCHERI; ASCHERI; CARVALHO, 2006). Dentre estes compostos, destacam-se as antocianinas, presentes em maior quantidade na casca da fruta e pertencentes ao grupo dos flavonóides (FENNEMA; DAMODARAN; PARKIN, 2010). Nas plantas, uma das funções das antocianinas é atrair polinizadores e dispersores de sementes, além da proteção contra processos de oxidação oferecida aos tecidos da planta, durante seu crescimento (HARBORNE, 1967, EIBOND et al., 2004).

As duas espécies mais cultivadas de jabuticaba são: a jabuticaba Sabará (Myrciaria jaboticaba (Vell.) Berg) e a jabuticaba Paulista (Myrciaria cauliflora (DC.) Berg). Outras espécies são menos comuns: M. coronata (coroada), M. oblongata (azeda), M. grandifolia (graúda), M. aureana (branca) e M. phitrantha (costada) (GOMES, 1983; DONADIO, 2000). A espécie Myrciaria cauliflora (DC) Berg possui ramos terminais e achatados, folhas com pecíolos de $3 \mathrm{~mm}$ de comprimento, frutos globosos, de cor negra, 2,2 a 2,9 cm de diâmetro, uma a quatro sementes e é conhecida como paulista, açu ou ponhema. Myrciaria jaboticaba (Vell) Berg é uma árvore de seis a nove metros de altura, ramos finos e cilíndricos, sendo os ramos terminais e novos, achatados, folhas com pecíolo de 1,5 a $2 \mathrm{~mm}$ de comprimento, 
frutos de 1,6 a 2,2 cm de diâmetro, subglobosos ou globosos, negros e lisos, uma a quatro sementes. Conhecida como sabará, de ocorrência no Brasil, Paraguai e Argentina (DONADIO, 2000), essa espécie é a mais conhecida no Brasil, sendo a mais apreciada e mais doce, com crescimento médio, mas muito produtiva e com maturação precoce, os frutos são miúdos, de epicarpo fino e quase preto (GOMES, 1972).

As cascas desses frutos são escuras, finas e muito frágeis, a polpa é branca a translúcida, mucilaginosa, doce, de pouca acidez e excelente aroma (LIMA et al., 2008). Nas indústrias de processamento de frutas, as cascas e sementes são desprezadas e representam juntas, praticamente, $50 \%$ do fruto, sendo que as cascas com grandes quantidades de antocianinas podem agregar um valor maior ao resíduo dessa fruta se reutilizadas. Há também quantidades consideráveis de fibra na casca da jabuticaba, com maior destaque para a pectina, a qual é importante no controle dos níveis sanguíneos de glicose e colesterol e auxilia na redução da ocorrência de doenças cardíacas e cálculos biliares (PEREIRA et al., 2000; PEREIRA et al., 2002; OLIVEIRA et al., 2003).

O aproveitamento de resíduos (cascas) de certos frutos, servindo de matéria prima para produção de alimentos é uma das alternativas que tem merecido destaque nas últimas décadas. Essas ideias são possíveis e concretas, visto que muitos resíduos são ricos em compostos bioativos, capazes de combater danos oxidativos causado pelos radicais livres, como no caso dos antioxidantes, substâncias consideradas de alto valor comercial (OLIVEIRA et al., 2002; MELO et al., 2011). As antocianinas da jabuticaba estão mais concentradas na casca do fruto, desta forma, a sua presença em resíduos oriundos do processamento da fruta justifica sua utilização como compostos bioativos com atividades antioxidantes e antimicrobianas (LIMA et al., 2011). De acordo com Almeida et al. (2015), as antocianinas presentes na casca da jabuticaba, extraídas com etanol e liofilização, foram eficientes contra a oxidação lipídica de mortadela tipo bologna refrigerada e armazenada por 35 dias.

\subsubsection{Antocianinas}

De acordo com Lima et al. (2011), Abe, Lajolo e Genovese (2012) e LeiteLegatti et al. (2012) as antocianinas, flavonóides responsáveis pela coloração escura da jabuticaba, estão mais concentradas na casca da fruta, suas moléculas são 
constituídas por duas ou três porções: uma aglicona (antocianidina), um grupo de açúcares e, frequentemente, um grupo de ácidos orgânicos (MALACRIDA; MOTTA, 2006).

As antocianidinas são as estruturas básicas das antocianinas, as quais consistem de um anel aromático (A) ligado a um anel heterocíclico $(C)$ que contém um oxigênio unido por uma ligação carbono-carbono com um terceiro anel aromático (B). As antocianidinas, quando encontradas em sua forma glicosídeo (ligada a uma porção de açúcar), são conhecidas como antocianinas (Figura 4).

Figura 4. Estrutura básica das antocianidinas.

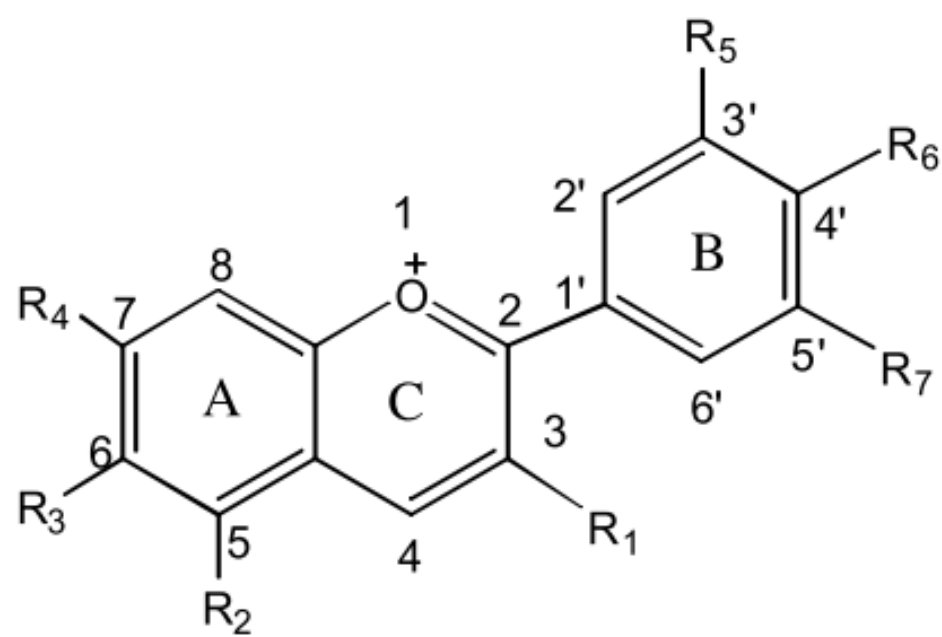

Fonte: CASTAÑEDA-OVANDO, A. et al. Chemical studies of anthocyanins: a review. Food Chemistry, Amsterdam, v. 113, n. 4, p. 859-871, 2009.

As antocianinas são antocianidinas ligadas a açúcares (glicose, ramnose, galactose, xilose, arabinose, frutose, rutinose, sambubiose e laritose), e essas estão ligados aos ácidos. A posição do açúcar na molécula exerce uma influência profunda na reatividade da antocianina. A substituição dos grupos hidroxila e metoxila têm influência na cor das antocianinas. O aumento de grupos hidroxilas acresce a coloração azulada, enquanto o aumento no grupo de metoxilas causa coloração vermelha (KONCZAK; ZHANG, 2004; ALIBERTI, 2009; CASTAÑEDA-OVANDO et al., 2009).

As antocianinas pertencem ao grupo dos flavonóides devido a sua característica de esqueleto carbônico $\mathrm{C}_{6} \mathrm{C}_{3} \mathrm{C}_{6}$, e dentro de cada grupo há muitos compostos diferentes, nos quais a cor depende da presença e do número de 
substituintes ligados à molécula. Quando há a remoção ou adição do íon hidrogênio na molécula ocorre mudança na cor (FENNEMA; DAMODARAN; PARKIN, 2010).

São conhecidas mais de 500 antocianinas, porém, apenas seis são as mais comuns em frutas e vegetais e estão distribuídas na seguinte proporção: $50 \%$ de cianidina, $12 \%$ de delfinidina, $12 \%$ de pelargonidina, $12 \%$ de peonidina, $7 \%$ de petunidina e $7 \%$ de malvidina. Os derivados glicosídeos mais disseminados na natureza são 3-monosídeos, 3-biosídeos, 3,5 e 3,7-diglicosídeos. A presença dos derivados 3-glicosídeo é mais frequente que o 3,5-diglicosídeo e a cianidina-3glicosídeo é a antocianina mais comumente localizada (KONG et al., 2003; CASTAÑEDA-OVANDO et al, 2009).

Segundo Lima et al. (2011) e Leite- Legatti et al. (2012), os quais estudaram as antocianinas presentes na jabuticaba, a cianidina-3-glicosídeo e delfinidina-3glicosídeo foram as mais comuns na casca da jabuticaba liofilizada.

As antocianinas são os pigmentos mais importantes das plantas, são seguros e de fácil incorporação em meio aquoso, tornando seu uso interessante como corantes naturais solúveis em água. Possuem propriedades importantes, tais como atividades antioxidantes e auxiliam na prevenção de doenças cardiovasculares e neural, câncer e diabetes (KONCZAK; ZHANG, 2004; CASTAÑEDA-OVANDO et al, 2009).

A cor resulta da excitação de uma molécula pela luz visível e a facilidade para que ocorra essa excitação depende da mobilidade eletrônica relativa da estrutura. As antocianinas são abundantes em duplas ligações, as quais são essenciais para a cor, sendo estas excitadas com facilidade. A intensidade da cor, a qual muda o comprimento de onda absorvido da luz, é afetada por interações hidrofóbicas e pontes de hidrogênio entre antocianinas e outros ácidos fenólicos presente em plantas. As antocianinas são instáveis e suscetíveis à degradação catalisada por enzimas, luz, calor, oxigênio, acidez e degradação oxidativa pelo ácido ascórbico (FENNEMA; DAMODARAN; PARKIN, 2010).

A maioria das antocianinas muda de cor dependendo do $\mathrm{pH}$, sendo a cor vermelha predominante em meio ácido, a cor azul em pH neutro e incolor em meio alcalino. As antocianinas, em solução aquosa, encontram-se em equilíbrio na forma de uma mistura de diferentes estruturas químicas: cátion flavilium (vermelho), base anidra quinoidal (azul), pseudobase carbinol (incolor), e chalcona (incolor ou levemente amarela). As antocianinas exibem coloração vermelha intensa apenas em uma faixa muito limitada de $\mathrm{pH}(1,0$ a 3,0) que corresponde a um equilíbrio entre o 
cátion flavilium (vermelho) e a base carbinol (incolor). Quando aumenta o pH, o cátion perde um próton e ganha uma molécula de água para formar pseudobase incolor carbinol. Esta por sua vez, pode numa taxa mais lenta se equilibrar com a forma incolor de chalcona. Em pH 4 e 6,5, o cátion flavilium perde um próton, formando uma base quinoidal de cor púrpura clara, que lentamente se hidrata para pseudobase carbinol, com desaparecimento progressivo da cor (ALIBERTI, 2009).

A presença de oxigênio pode causar a degradação das antocianinas pelo mecanismo de oxidação direta ou indireta dos constituintes do meio que reagem com as antocianinas. Ácido ascórbico e oxigênio podem degradar a antocianina, pela oxidação indireta do peróxido de hidrogênio formado durante a oxidação aeróbica do ácido ascórbico (ALIBERTI, 2009).

Vale ressaltar que a estabilidade dos pigmentos extraídos de frutas e vegetais pode ser afetada pela exposição ao $\mathrm{pH}$, enzimas, temperatura, luz solar, íons metálicos e oxigênio e uma das formas de evitar a sua degradação é a secagem por atomização, a qual tem como principal objetivo microencapsular o pigmento (CASTAÑEDA-OVANDO et al., 2009; FANG e BHANDARI, 2010). A microencapsulação pode ser definida como um processo no qual uma membrana envolve pequenas partículas de sólido, líquido ou gás com a finalidade de proteger o material das condições adversas do meio, tais como luz, umidade, oxigênio e interações com outros compostos, estabilizando o produto e aumentando sua vida útil (SHAHIDI e HAN, 1993). 


\section{OBJETIVOS}

\subsection{Objetivo geral}

O presente projeto teve como objetivo utilizar o extrato de jabuticaba (Myrciaria cauliflora) microencapsulado como corante natural, em linguiça frescal e mortadela, avaliando seu potencial antimicrobiano e antioxidante em substituição ao corante carmim de cochonilha tradicionalmente utilizado nesses produtos.

\subsection{Objetivos específicos}

$\checkmark$ Avaliar o potencial antimicrobiano do extrato de jabuticaba em diferentes concentrações sobre Staphylococcus aureus ATCC 25923, Escherichia coli ATCC 25922 e Salmonella Enteritidis ATCC 13076;

$\checkmark$ Avaliar a capacidade antioxidante do extrato de jabuticaba aquoso e microencapsulado;

$\checkmark$ Avaliar a estabilidade físico-química, microbiológica e sensorial da linguiça frescal fabricada sem corante, com carmim de cochonilha e extrato de jabuticaba microencapsulado (EJM);

$\checkmark$ Avaliar a estabilidade físico-química, microbiológica, e sensorial da mortadela fabricada sem corante, com carmim de cochonilha e extrato de jabuticaba microencapsulado (EJM). 


\section{HIPÓTESE}

A utilização de extrato de jabuticaba microencapsulado pode oferecer coloração aos embutidos cárneos dos tipos linguiça frescal e mortadela e, se adicionado em concentrações adequadas, pode apresentar atividades antioxidante e antimicrobiana sem alterar o sabor desses produtos. 


\section{MATERIAL E MÉTODOS}

5.1 Obtenção do extrato de jabuticaba microencapsulado e determinação in vitro de seu potencial antioxidante e antimicrobiano

\subsubsection{Obtenção e microencapsulação do extrato aquoso de jabuticaba}

Para obtenção do extrato, a matéria-prima utilizada foi o resíduo do processamento de jabuticaba (casca e semente) da variedade Paulista. A jabuticaba foi adquirida no comércio da cidade de Pirassununga-SP e o extrato aquoso foi obtido de acordo com o procedimento descrito por Silva et al. (2014), com modificações. Foram processados 223,57 quilos de jabuticaba in natura e inicialmente foi realizado um branqueamento, por imersão em água em ebulição por 5 minutos, para inativar enzimas e reduzir o número de microrganismos na superfície das frutas. Para a obtenção do extrato, foi utilizada uma despolpadeira mecânica (Recifer, modelo MR DSI 400, Brasil) para separar a polpa da casca e da semente, obtendo-se assim o resíduo. O total de resíduo obtido foi de $52,13 \mathrm{~kg}$ os quais foram embalados a vácuo com o auxílio de uma embaladeira semi-automática (Selovac, modelo 200S, Brasil) utilizando filme de polietileno de baixa densidade. Após embalado, o resíduo foi congelado a $-18^{\circ} \mathrm{C}$ (Figuras 5 e 6 ). 
Figura 5. Fluxograma para obtenção da casca e semente da jabuticaba.

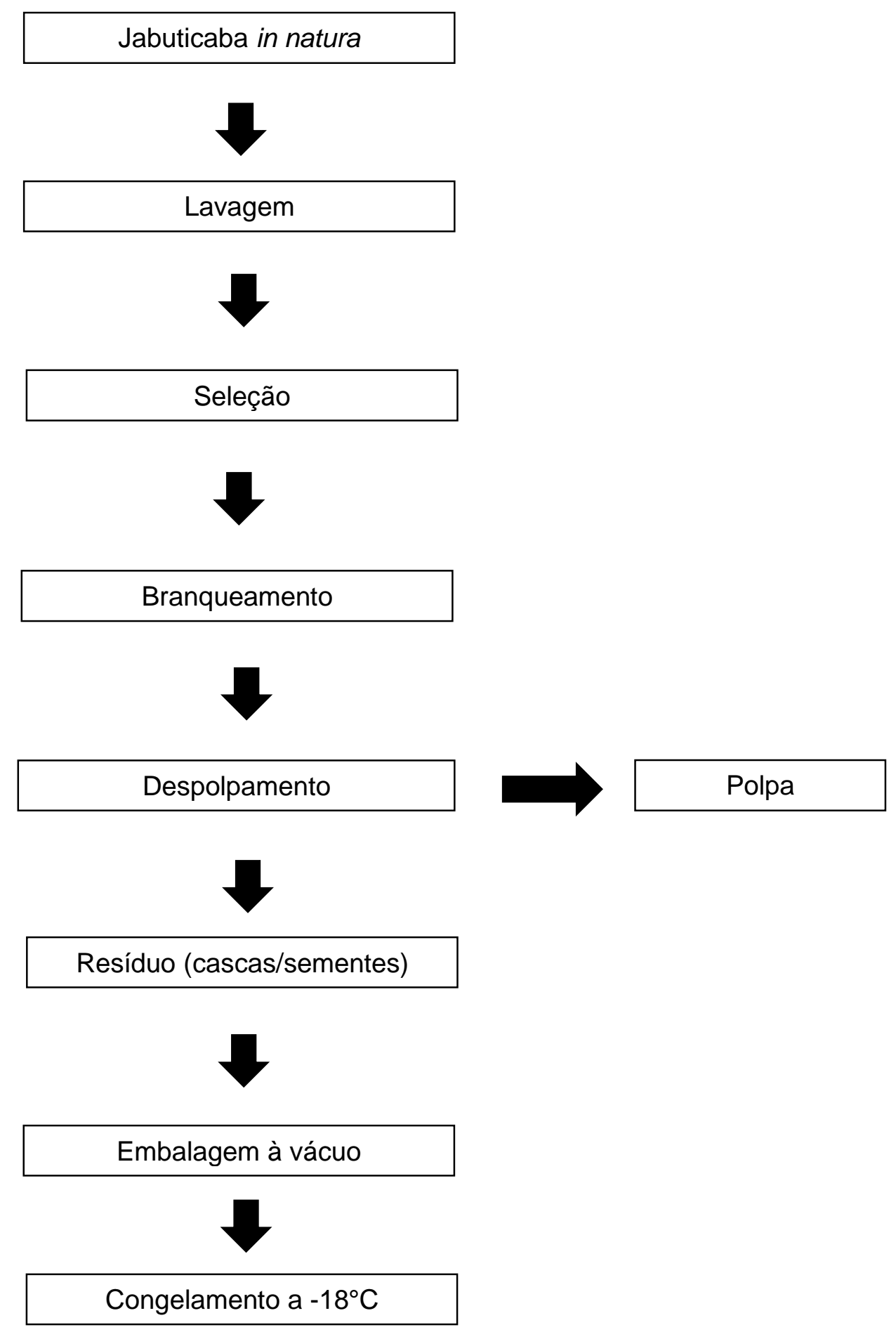


Figura 6. Processo de obtenção do extrato da casca da jabuticaba - a) branqueamento da jabuticaba inteira; b) despolpamento da casca da jabuticaba; c) embalagem a vácuo em embaladeira semi-automática; d) resíduo (cascas e sementes) da jabuticaba embalado a vácuo.

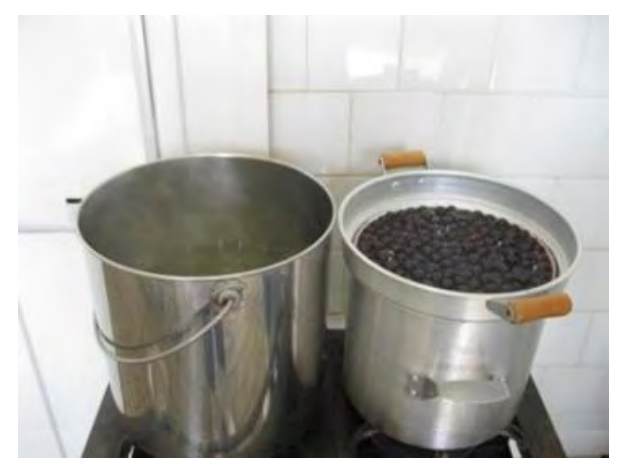

(a)

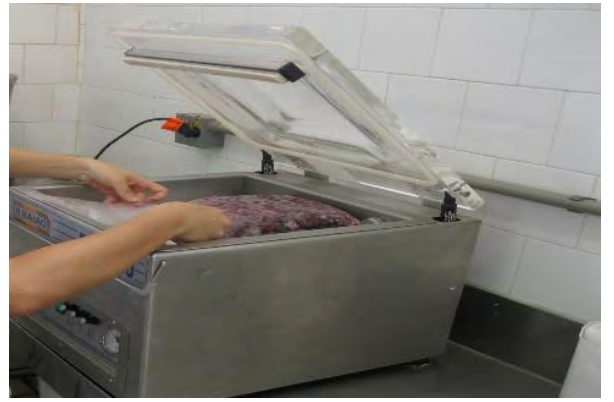

(c)

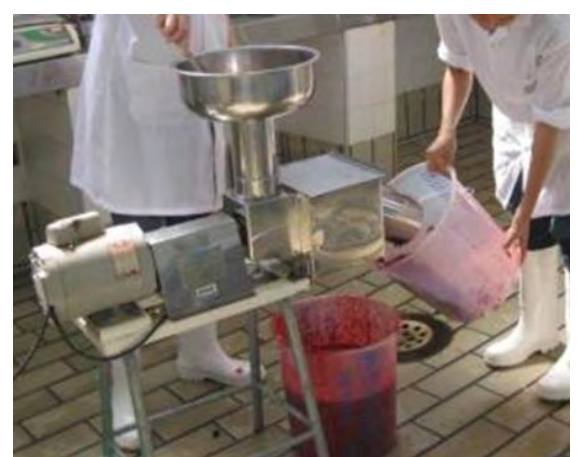

(b)

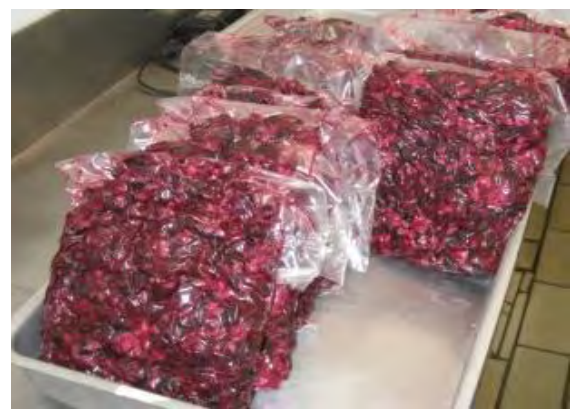

(d)

Fonte: Própria autoria.

Após descongelamento em estufa BOD a $4 \pm 1^{\circ} \mathrm{C}$ por 12 horas, a extração do pigmento da jabuticaba foi realizada com adição de água destilada na proporção de 1:3 (resíduo: água) (TERCI; ROSSI, 2002), com isso utilizou-se 52,13 kg de casca e semente de jabuticaba e 156,39 L de água destilada na ausência de luz sob agitação mecânica controlada a 6500 rpm (Agitador 713, Fisaton, Brasil) durante seis horas. Em seguida, o fluido obtido foi filtrado com o auxílio de uma peneira de $18 \mathrm{~cm}$ de diâmetro com orifícios de $0,2 \mathrm{~cm}^{2}$. O extrato bruto foi concentrado a $1 / 3$ de seu volume inicial utilizando um evaporador rotativo (TE-102, Tecnal, Brasil) a $60^{\circ} \mathrm{C}$ acoplado a uma bomba de vácuo (TE-058, Tecnal, Brasil) operando a $600 \mathrm{mmHg}$, obtendo-se 69,50 L de extrato concentrado, armazenado em frascos plásticos de $500 \mathrm{~mL}$ com tampa e congelados $\mathrm{a}-18^{\circ} \mathrm{C}$ (Figuras 7 e 8 ). 
Figura 7. Fluxograma para a obtenção do extrato concentrado da casca da jabuticaba.

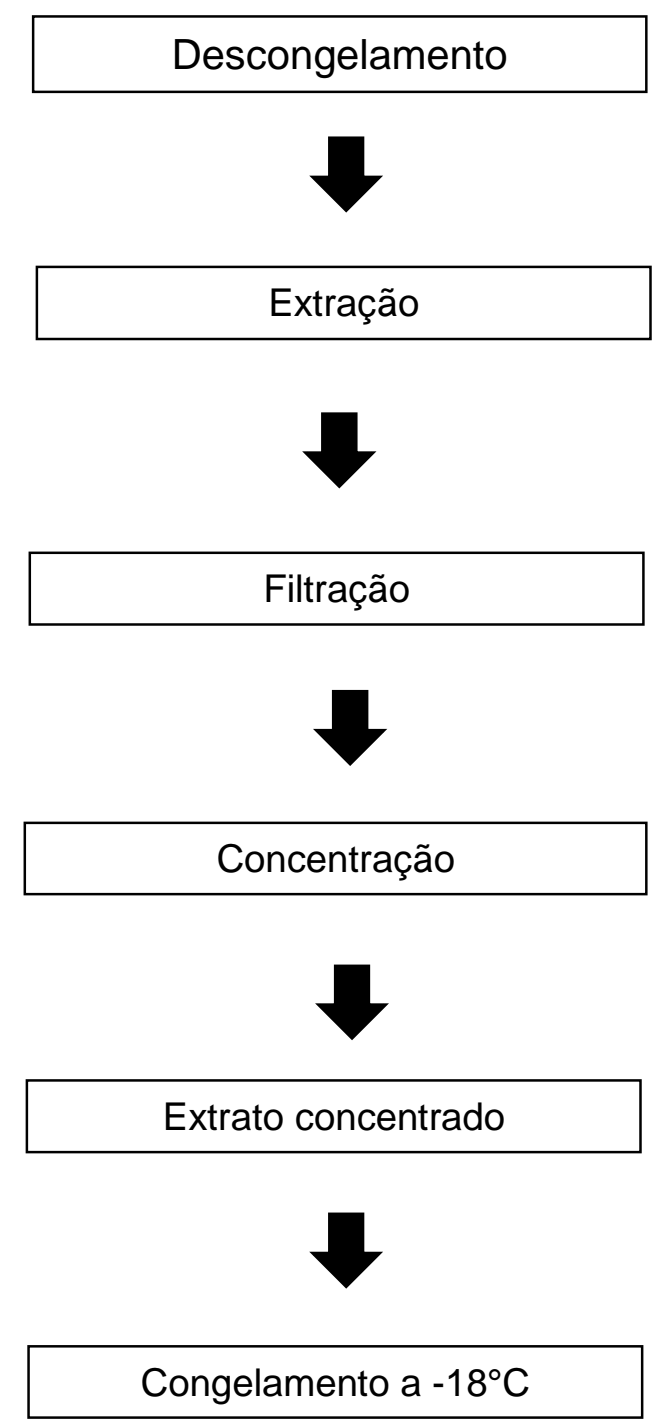


Figura 8. Extração do pigmento da casca da jabuticaba - a) Resíduo (cascas e sementes) da jabuticaba; b) extração do pigmento da casca da jabuticaba; c) concentração do extrato obtido em evaporador rotativo.

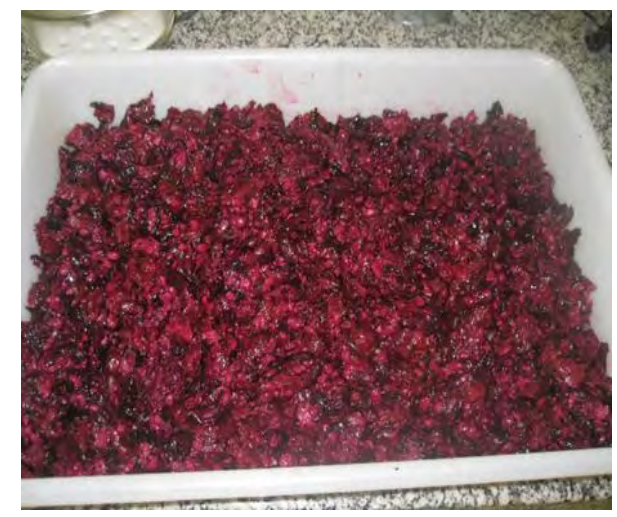

a)

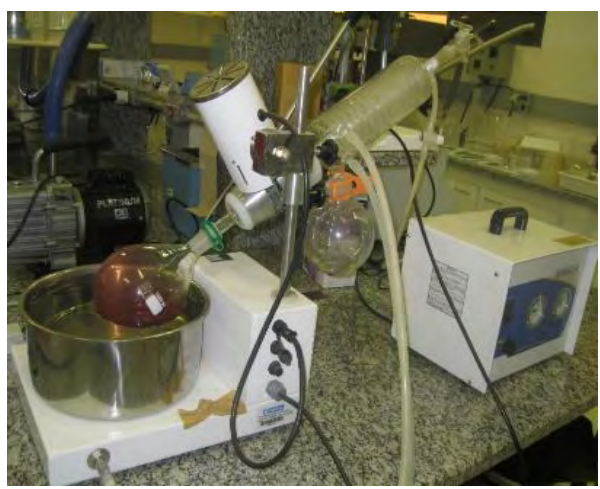

c)

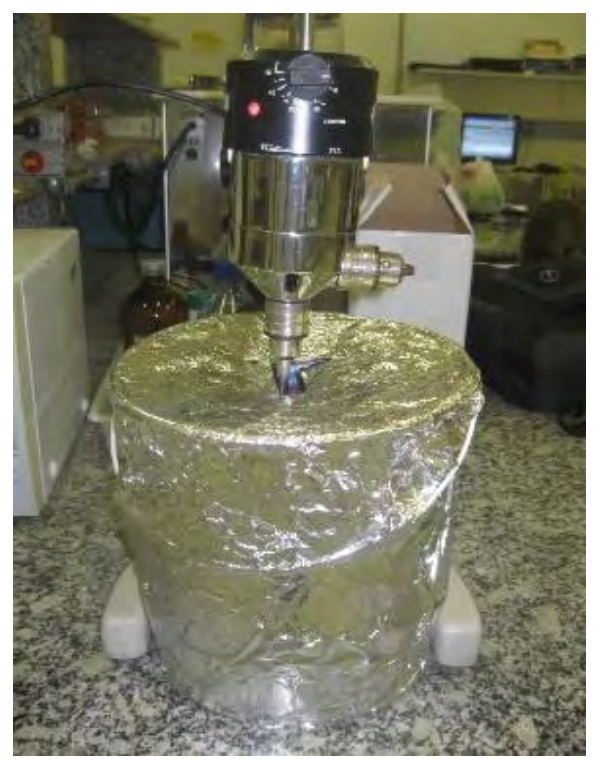

b)

Fonte: Própria autoria.

Posteriormente, o extrato aquoso foi descongelado em estufa BOD a $4 \pm 1^{\circ} \mathrm{C}$ por 12 horas e misturado com maltodextrina MOR-REX® 1910 (DE10) (Ingredion, MogiGuaçu, Brasil) usando um agitador mecânico (Fisaton 713, São Paulo, Brasil) e microencapsulado em um spray dryer (modelo MSD 5.0 Labmaq, Ribeirão Preto, Brasil) com bico injetor de 1,5 mm de diâmetro e fluxo de ar de $40 \mathrm{~L} / \mathrm{min}$. As variáveis independentes foram $150^{\circ} \mathrm{C}$ de temperatura de entrada do ar de secagem, $30 \mathrm{~mL} / \mathrm{min}$ de vazão mássica da alimentação e a concentração do agente carreador foi $26 \%$ do conteúdo total de extrato aquoso (260 g de maltodextrina/kg de extrato). A quantidade 
total foi de $18,07 \mathrm{~kg}$ de maltodextrina e $69,50 \mathrm{~L}$ de extrato de jabuticaba aquoso concentrado. $O$ total de extrato microencapsulado foi de 8,04 kg (Figura 9).

Figura 9: Processo de microencapsulação do extrato de jabuticaba - a) Equipamento para secagem Spray dryer; b) e c) Extrato de jabuticaba microencapsulado.

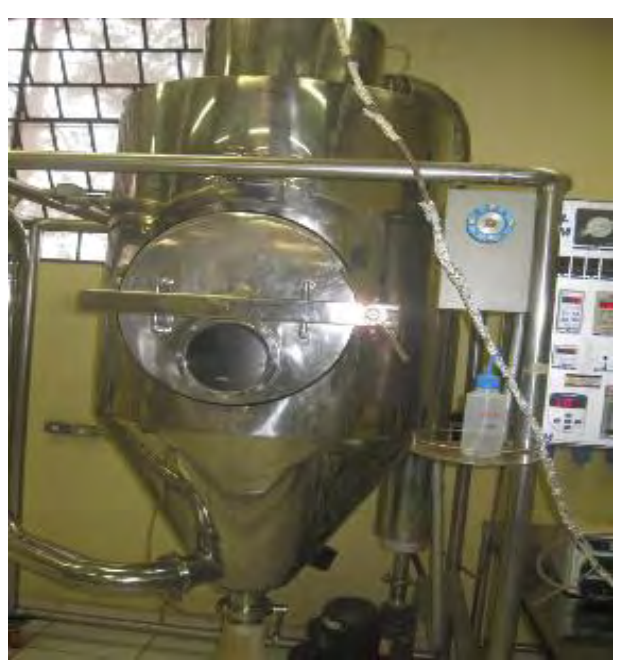

a)

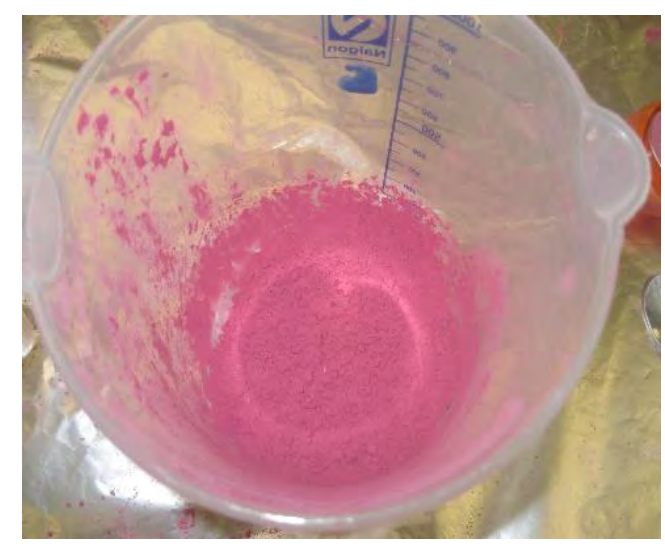

c)

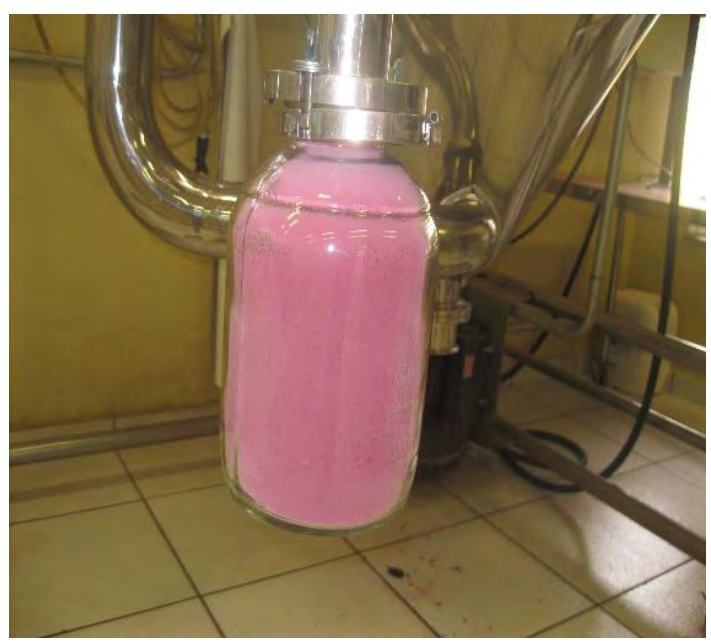

b)

Fonte: Própria autoria.

Para caracterização física do extrato foram avaliados $\mathrm{opH}$ medido em potenciômetro (modelo MB-10, Marte, Brasil) e o teor de sólidos solúveis, medido em refratômetro digital portátil (modelo AR200, Reichert, Depew, Estados Unidos). 


\subsubsection{Determinação do teor de antocianinas totais}

A análise do conteúdo total de antocianinas foi realizada utilizando-se o método da diferença de pH (GIUSTI; WROLSTAD, 2001). Uma massa conhecida de cada amostra foi diluída em água com o volume ajustado para $25 \mathrm{~mL}$. Para uma alíquota de $0,5 \mathrm{~mL}$ de amostra diluída foram adicionados 4,5 $\mathrm{mL}$ do tampão cloreto de potássio $(\mathrm{pH} 1,0)$ em tubos de ensaio em triplicata, homogeneizados e armazenados por 15 minutos em ausência de luz, sendo realizado procedimento equivalente com o tampão acetato de sódio ( $\mathrm{pH} 4,5)$. A determinação da absorbância foi medida no comprimento de onda de absorção máxima 510 nm e a 700 nm em um espectrofotômetro (modelo Libra S-22, Biochrom, Cambridge, UK), e o branco feito com uma solução do agente carreador maltodextrina 10 DE. A diferença na absorbância foi calculada de acordo com a eq. (1). O teor de antocianinas totais em $\mathrm{mg} / \mathrm{L} \mathrm{da}$ amostra diluída foi calculado conforme descrito na eq. (2). Os resultados foram expressos em miligrama equivalente de cianidina-3-glicosídeo por grama de extrato. Foram utilizados o coeficiente de extinção molar da cianidina-3-glicosídeo $(\varepsilon=26.900 \mathrm{~L} / \mathrm{cm} . \mathrm{mol})$ e o peso molecular de 449,2 g/mol (ROCKENBACH et al. 2011).

$$
A=(\text { Abs } 510 \mathrm{~nm}-\operatorname{Abs} 700 \mathrm{~nm}) \mathrm{pH} 1-(\text { Abs } 510 \mathrm{~nm}-\text { Abs } 700 \mathrm{~nm}) \mathrm{pH} 4,5
$$

Onde: A é a diferença das absorbâncias nos diferentes valores de $\mathrm{pH}$.

$$
\text { AT } \mathrm{mg} / \mathrm{L}=\frac{(\mathrm{A} \times 449,2 \times \mathrm{FD} \times 1000)}{26900}
$$

Onde: AT mg/L é o teor de antocianinas totais expressos em $\mathrm{mg}$ equivalente de cianidina-3-glicosídeo por litro de amostra diluída e FD é o fator de diluição $(=10)$ da amostra nas soluções tampão. 


\subsubsection{Identificação das antocianinas por cromatografia líquida de alta eficiência (CLAE), espectrometria de massas (MS) e quantificação por detector de arranjos de diodos (DAD)}

As antocianinas foram determinadas em condições analíticas modificadas a partir da metodologia descrita por Ordaz-Galindo et al. (1999).

\subsubsection{Extração em fase sólida}

Transferiu-se $1 \mathrm{~mL}$ do extrato centrifugado para uma coluna de poliamida (Agilent QPT, $30 \mathrm{mg}$ ) para extração em fase sólida. A coluna foi previamente condicionada com $2 \mathrm{~mL}$ de metanol (Panreac) e equilibrada com $2 \mathrm{~mL}$ de água ultrapura (Millipore). Após lavagens com $6 \mathrm{~mL}(3 \times 2 \mathrm{~mL})$ de água ultrapura, as antocianinas foram eluídas com $1 \mathrm{~mL}$ de metanol acidificado com ácido fórmico (Sigma) para $\mathrm{pH}$ 2,0. Ao eluído adicionou-se $1 \mathrm{~mL}$ de naringenina (padrão interno) $0,09 \mathrm{mg}$. $\mathrm{mL}^{-1}$ dissolvida em metanol. A solução foi filtrada em membrana de nylon $0,45 \mu \mathrm{m} 13 \mathrm{~mm}$ d.i. para análise por cromatografia líquida de alta eficiência.

\subsubsection{Identificação por espectrometria de massas (MS)}

Foi usado um sistema de cromatografia líquida de ultra performance marca Waters, modelo Acquity, com detector de massas triplo quadrupolo, modelo Xevo TQD com a seguinte configuração (software MassLink SCN855): voltagem do capilar em 3 $\mathrm{kV}$, energia de colisão $30 \mathrm{~V}$, dissociação induzida por colisão com gás argônio, fluxo de infusão de $20 \mu \mathrm{L}$. $\mathrm{min}^{-1}$ no modo combinado com fase móvel (50\% de acetonitrila e $50 \%$ de ácido fórmico $0,01 \%$ ) em $0,50 \mathrm{~mL} \cdot \mathrm{min}^{-1}$, temperatura da fonte $\mathrm{ESI} 150^{\circ} \mathrm{C}$, temperatura de dessolvatação $500^{\circ} \mathrm{C}$, fluxo de nitrogênio 800 L.h ${ }^{-1}$.

\subsubsection{Análise por cromatografia líquida de alta eficiência com detector de arranjo de diodos (CLAE - DAD)}

Foi utilizado um sistema de cromatografia líquida de alta eficiência da marca Shimadzu, modelo Prominence, equipado com bomba quaternária, gaseificador, injetor automático, compartimento de coluna, detector por arranjo de diodos e software 
LC Solution. A coluna analítica C18 Shim-Pack VP-ODS (Shimadzu) de 250 x 4,6mm com $5 \mu \mathrm{m}$ de tamanho de partícula foi mantida a $30^{\circ} \mathrm{C}$. Os solventes foram água ultrapura (Millipore) acidificada com ácido fosfórico (Synth) 0,1 M para pH 4,0 (fase móvel A) e acetonitrila (Panreac) (fase móvel B). O tempo de corrida foi de 25 minutos com fluxo da fase móvel de $1 \mathrm{~mL} \cdot \mathrm{min}^{-1}$ usando a seguinte programação: $5 \%$ de $\mathrm{B}$ no início, 50\% de B em 10 minutos, 100\% de B em 15 minutos, 5\% de B em 20 minutos, $5 \%$ de $\mathrm{B}$ de 20 a 25 minutos. Injetou-se $10 \mu \mathrm{L}$ das amostras com detecção em 280 $\mathrm{nm}$ para naringenina (padrão interno) e $530 \mathrm{~nm}$ para antocianinas. Os espectros eletrônicos das antocianinas foram coletados para auxiliar na identificação. Os resultados foram expressos em base seca em miligrama por $100 \mathrm{~g}$ de amostra.

\subsubsection{Capacidade antioxidante in vitro}

\subsubsection{Método Folin-Ciocalteu (Fenólicos totais)}

A análise foi realizada de acordo com Georgé et al. (2005) com modificações. Em tubo eppendorff de $2 \mathrm{~mL}$ foram misturados $100 \mu \mathrm{L}$ de amostra diluída em água destilada em $500 \mu \mathrm{L}$ da solução de Folin-Ciocalteu. Após 2 minutos foram adicionados $400 \mu \mathrm{L}$ de solução carbonato de sódio 7,5\% aos tubos, seguidos de homogeneização. As amostras, preparadas em triplicata, foram colocadas em banho-maria a $50^{\circ} \mathrm{C}$ por 15 minutos. A absorbância a $760 \mathrm{~nm}$ foi determinada em espectrofotômetro (Ultrospec 2000, Pharmacia Biotech) e o conteúdo de fenólicos totais calculado utilizando-se curva-padrão de ácido gálico (Sigma Chemical Co., St. Louis, USA). Os resultados obtidos foram expressos como miligrama equivalente de ácido gálico/grama de amostra.

\subsubsection{Capacidade Redutora do Ferro (FRAP)}

A análise pelo reagente FRAP foi realizada a partir da mistura de tampão acetato de sódio 300 mM pH 3,6 com 2,4,6-tripiridil-s-triazina (TPTZ-Sigma-Aldrich Chemical Co., Bellefonte, PA), $10 \mathrm{mM}$ em solução $\mathrm{HCl} 40 \mathrm{mM}$ e cloreto férrico $\left(\mathrm{FeCl}_{3} .6 \mathrm{H}_{2} \mathrm{O}\right) 20 \mathrm{mM}$ na proporção de 10:1:1, respectivamente. Os ensaios foram realizados em triplicata e colocados em banho-maria a $37^{\circ} \mathrm{C}$ por 30 minutos e a leitura das amostras realizada em espectrofotômetro (Ultrospec 2000, Pharmacia Biotech) a 
$593 \mathrm{~nm}$. Os resultados foram obtidos por meio de uma curva de calibração com uma solução $1000 \mu \mathrm{M}$ de Trolox e expressos como micromol de equivalente Trolox por litro de extrato (BENZIE; STRAIN, 1996).

\subsubsection{Atividade antioxidante pelo radical DPPH'}

A determinação da atividade antioxidante pelo método DPPH foi feita de acordo com a metodologia de Brand-Williams, Cuvelier e Berset (1995). A extração foi realizada adicionando-se $20 \mathrm{~mL}$ de água a $0,01 \mathrm{~g}$ de amostra. Alíquotas de $0,1 \mathrm{~mL}$ destes extratos foram colocadas em diferentes tubos de ensaios e adicionadas de 3,9 $\mathrm{mL}$ da solução de DPPH (2,2-difenil-1-picril-hidrazila, Sigma-Aldrich Chemical Co., Bellefonte, PA) em metanol ( $\left.6 \times 10^{-5} \mathrm{M}\right)$. Após agitação, os tubos foram deixados em repouso ao abrigo da luz e, após 60 minutos, a absorbância foi medida a $515 \mathrm{~nm}$. A mesma análise foi feita para soluções de Trolox em várias diluições, permitindo a construção de uma curva padrão. Os resultados foram demonstrados em milimol de equivalente Trolox por litro de extrato.

\subsubsection{Atividade antimicrobiana in vitro}

\subsubsection{Microrganismos testados}

Foram utilizadas cepas padrão das bactérias Staphylococcus aureus ATCC 25923, Escherichia coli ATCC 25922 e Salmonella Enteritidis ATCC 13076 da coleção de cepas do laboratório Multiusuário de Microbiologia da Universidade de São Paulo (FZEA/USP), as quais foram adquiridas da empresa Comércio Importação e Exportação Bioscan Ltda, situada na cidade de Itu/SP, Brasil.

\subsubsection{Determinação da atividade antimicrobiana}

O teste foi realizado de acordo com a norma NCCLS M7-A6 (NCCLS, 2003) e determinação de Martin et al. (2012) com modificações. Foram preparados e autoclavados a $121 \pm 1^{\circ} \mathrm{C}$ por 15 minutos $150 \mathrm{~mL}$ de Ágar Muller Hinton (Difco, USA), mantido a $45 \pm 1^{\circ} \mathrm{C}$. Foram adicionados $150 \mu \mathrm{L}$ de suspensão bacteriana a $1 \times 10^{8}$ unidades formadoras de colônias (UFC) /mL para que a concentração final ficasse em 
torno de $1,5 \times 10^{5} \mathrm{UFC} / \mathrm{mL}$. Foram transferidos $75 \mathrm{~mL}$ para placas de Petri de $150 \mathrm{~mm}$ estéreis e após a solidificação foram produzidos poços de $8 \mathrm{~mm}$ de diâmetro. A estes poços, foram adicionados $40 \mu \mathrm{L}$ das diluições do extrato de jabuticaba nas concentrações de 10, 25, 50, 80 e 100\% para o extrato aquoso e 50, 100, 150, 200 e $300 \mathrm{mg} / \mathrm{mL}$ para o extrato microencapsulado. Como controle negativo foi utilizada solução salina $0,9 \%$ (Samtec, Brasil) e como controle positivo foi utilizado cloranfenicol $2,5 \mathrm{mg} / \mathrm{mL}$. Os testes foram feitos em duplicata. Após uma hora, as placas foram incubadas a $37 \pm 1^{\circ} \mathrm{C}$ por $24 \mathrm{~h}$. Após incubação foram mensurados os diâmetros dos halos formados.

\subsubsection{Determinação da Concentração Inibitória Mínima (CIM) e Concentração Bactericida Mínima (CBM)}

Para a determinação da CIM foi utilizada a técnica de microdiluição, com placas estéreis de 96 poços com fundo em "U" (NCCLS, 2003). Foram adicionados $95 \mu \mathrm{L}$ de caldo BHI (Brain Heart Infusion, Acumedia, Brasil) nos poços, em seguida realizadas dez diluições seriadas do extrato de jabuticaba $(50 \mathrm{mg} / \mathrm{mL}$ a $0,097 \mathrm{mg} / \mathrm{mL}$ para o extrato aquoso e $150 \mathrm{mg} / \mathrm{mL}$ a $0,29 \mathrm{mg} / \mathrm{mL}$ para o extrato microencapsulado), com adição do inóculo na concentração de $5 \times 10^{5} \mathrm{UFC} / \mathrm{mL}$ em cada poço. Como controle positivo foi utilizado cloranfenicol $2,5 \mathrm{mg} / \mathrm{mL}$ e como controle negativo o caldo $\mathrm{BHI}$ (Brain Heart Infusion, Acumedia, Brasil). O volume final de cada poço foi de $100 \mu \mathrm{L}$. A placa foi selada com filme de vedação (Z369667, Sigma, Saint Louis, USA) e incubada a $37 \pm 1^{\circ} \mathrm{C}$ por 24 horas. Após a incubação foram adicionados $40 \mu \mathrm{L}$ de ITT (Cloreto lodonitrotetrazólico - 18377- Sigma, Saint Louis, USA) $2 \mathrm{mg} / \mathrm{mL}$ em cada poço e foi então verificada a CIM. A partir desta concentração foram transferidos $100 \mu \mathrm{L}$ para placas contendo ágar BHI (Brain Heart Infusion, Acumedia, Brasil), com semeadura em superfície e incubação a $37 \pm 1^{\circ} \mathrm{C}$ por 24 horas para verificar a CBM. Os testes foram feitos em duplicata. 


\subsection{Aplicação do extrato de jabuticaba microencapsulado em embutidos cárneos}

\subsubsection{Produção da linguiça frescal}

A paleta e o toucinho suíno foram adquiridos em um mercado local na cidade de Pirassununga/SP, estocadas em estufa BOD (Fanem, Brasil) à $1 \pm 1^{\circ} \mathrm{C}$ e processadas no dia seguinte. A carne e o toucinho foram moídos em moinho industrial (Modelo: Picador 22, Beccaro, Brasil), utilizando-se disco de $8 \mathrm{~mm}$. A carne e o toucinho moído e os demais ingredientes foram misturados durante, aproximadamente, 5 minutos em misturador. Os ingredientes e aditivos utilizados foram: sal $(\mathrm{NaCl})$, condimento para toscana (Doremus, São Paulo, Brasil) e tripolifosfato de sódio (Ligagel E004, Doremus, São Paulo, Brasil). O embutimento da massa cárnea foi feito em tripa natural de suíno calibre $28 \mathrm{~mm}$ em embutideira seguido da amarração dos gomos em tamanhos de $15 \mathrm{~cm}$. Após esses procedimentos, as linguiças frescais foram embaladas em sacos pláticos de polietileno (sem vácuo) e estocadas em estufa BOD (Fanem, Brasil) a $1 \pm 1^{\circ} \mathrm{C}$ por 15 dias e as formulações usadas estão apresentadas na Tabela 1.

Tabela 1. Composição dos diferentes tratamentos para linguiça frescal.

\begin{tabular}{ccccc}
\hline & \multicolumn{4}{c}{ Quantidades (\%) } \\
\hline Ingredientes & Controle & $\begin{array}{c}\text { Carmim de } \\
\text { cochonilha }\end{array}$ & $\begin{array}{c}\text { Jabuticaba } \\
\mathbf{2 \%}\end{array}$ & $\begin{array}{c}\text { Jabuticaba } \\
\mathbf{4 \%}\end{array}$ \\
\hline Paleta suína & 70 & 70 & 67,75 & 65,75 \\
Toucinho suíno & 25 & 25 & 25 & 25 \\
Água & 2.75 & 2.94 & 3 & 3 \\
Sal (NaCl) & 1 & 1 & 1 & 1 \\
Condimento para toscana & 1 & 1 & 1 & 1 \\
Tripolifosfato de sódio & 0,25 & 0,25 & 0,25 & 0,25 \\
Carmim de Cochonilha & 0 & 0,06 & 0 & 0 \\
Extrato de jabuticaba & & 0 & 2 & 4 \\
microencapsulado & 0 & 0 & 100 & 100 \\
Total & 100 & 100 &
\end{tabular}

Controle: Linguiça frescal sem adição de corante; Carmim de cochonilha: linguiça frescal com corante tradicional carmim de cochonilha; Jabuticaba $2 \%$ : linguiça frescal com adição de $2 \%$ de Extrato de Jabuticaba Microencapsulado (EJM); Jabuticaba 4\%: linguiça frescal com adição de $4 \%$ de EJM.

Fonte: Própria autoria. 


\subsubsection{Produção da mortadela}

As matérias-primas cárneas utilizadas (carne bovina e carne mecanicamente separada de frango - CMS) foram definidas buscando-se um produto o mais parecido possível com aqueles normalmente comercializados no Brasil, onde é permitida a adição de até $60 \%$ de CMS em mortadelas. A carne bovina e a CMS foram adquiridas em mercado local na cidade de Pirassununga/SP, estocadas em estufa BOD (Fanem, Brasil) à $1 \pm 1^{\circ} \mathrm{C}$ e processadas no dia seguinte (BRASIL, 2001). Os demais ingredientes e aditivos utilizados foram: sal ( $\mathrm{NaCl}$ ), nitrito de sódio (Cura 001, Doremus, São Paulo, Brasil), condimento para mortadela (Doremus, São Paulo, Brasil), tripolifosfato de sódio (Ligagel E004, Doremus, São Paulo, Brasil) e fécula de mandioca (Yoki, São Paulo, Brasil). Para o processamento, as carnes e todos os ingredientes/aditivos foram pesados, separadamente, conforme descrito na Tabela 2. As massas de mortadela foram cominuídas em homogeneizador rotativo de bacia ("cutter", marca: Tecmafrig, Brasil), por aproximadamente 5 minutos, sendo retiradas deste equipamento com temperaturas inferiores a $12^{\circ} \mathrm{C}$. Em seguida, as emulsões foram embutidas em tripas plásticas com diâmetro de $50 \mathrm{~mm}$ (Viskase, Brasil). O cozimento foi realizado em estufa com o seguinte ciclo de aquecimento: cozimento com vapor direto por uma hora à $60 / 65^{\circ} \mathrm{C}$, uma hora à $70 / 75^{\circ} \mathrm{C}$ e foi finalizado o cozimento com $80 / 85^{\circ} \mathrm{C}$ até atingir a temperatura interna de $72^{\circ} \mathrm{C}$, a seguir as mortadelas foram resfriadas em água corrente, e estocadas em estufa BOD (Fanem, Brasil) a $4 \pm 1^{\circ} \mathrm{C}$ por 56 dias para realização das análises. 
Tabela 2. Composição dos diferentes tratamentos para mortadela.

\begin{tabular}{cccc}
\hline Ingredientes & \multicolumn{3}{c}{ Quantidades (\%) } \\
\cline { 2 - 4 } & Controle & Carmin de cochonilha & Jabuticaba \\
\hline Carne bovina & 25 & 25 & 25 \\
Carne Mecanicamente Separada & & 60 & 60 \\
de frango (CMS) & 60 & 7,5 & 5,5 \\
Gelo & 7,5 & 5,0 & 5,0 \\
Fécula de mandioca & 5,0 & & 2,0 \\
Extrato de jabuticaba & & 0 & 0 \\
microencapsulado & 0 & 0,05 & 0,25 \\
Carmim de cochonilha & 0 & 0,25 & 0,25 \\
Nitrito de sódio & 0,25 & 0,25 & 1,0 \\
Tripolifosfato de sódio & 0,25 & 1,0 & 1,0 \\
Condimento para mortadela & 1,0 & 1,0 & 100 \\
Sal (NaCl) & 1,0 & 100 & \\
Total & 100 & &
\end{tabular}

Controle: Mortadela sem adição de corante; Carmim de cochonilha: mortadela com corante tradicional carmim de cochonilha; Jabuticaba: mortadela com adição de $2 \%$ de Extrato de Jabuticaba Microencapsulado (EJM).

Fonte: Própria autoria.

\subsubsection{Composição centesimal da linguiça frescal e mortadela}

A metodologia oficial da Association of Official Analytical Chemistry (AOAC) foi utilizada para determinação da umidade (AOAC 950.46) e cinzas (AOAC 920.153). O teor de lipídeos foi determinado pelo método de Bligh e Dyer (1959) e proteínas por método de Dumas (AOAC 992.15), utilizando-se sistema completo para determinação de nitrogênio/proteína por combustão rápida (FP-528, Leco, Brasil). As análises foram realizadas em triplicata, as quais foram trituradas em um processador de alimentos (RI7620, Philips Walita, Brasil) por $2 \mathrm{~min}$, totalizando aproximadamente 500 gramas de amostra por tratamento. Os resultados foram expressos em porcentagem (\%).

\subsubsection{Umidade}

As amostras foram pesadas (aproximadamente 5 gramas) em placas de Petri em balança analítica (Shimadzu, Brasil) e colocadas em uma estufa de secagem (Fanem, Brasil) à $105 \pm 1^{\circ} \mathrm{C}$ por aproximadamente 24 horas. A pesagem foi realizada em intervalos de tempo até que a diferença de massa entre duas pesagens sucessivas não excedesse $0,1 \%$ da massa da amostra. 


\subsubsection{Cinzas}

Para determinação de cinzas, os cadinhos de cerâmica foram calcinados em mufla (Fornitec, Brasil) à $550^{\circ} \mathrm{C}$ por 24 horas. As amostras resultantes das análises de umidade foram colocadas na mufla nesta mesma temperatura por 96 horas, até que os resíduos ficassem brancos, após este tempo foi realizada a pesagem e apresentação dos resultados.

\subsubsection{Lipídeos}

O método utilizado para determinação de lipídeos foi extração com solvente a frio de acordo com Bligh e Dyer (1959) com adaptações. Foram pesados 2,5 gramas de amostra e homogeneizadas por 30 minutos em mesa agitadora com $25 \mathrm{~mL}$ de clorofórmio (Synth, Brasil), $50 \mathrm{~mL}$ de metanol (Synth, Brasil) e $20 \mathrm{~mL}$ de água destilada. Após este tempo foram adicionados $50 \mathrm{~mL}$ de clorofórmio (Synth, Brasil) e $25 \mathrm{~mL}$ de sulfato de sódio 1,5\% (Synth, Brasil) e colocados em mesa agitadora por 20 minutos. Após 24 horas foi recolhida a fase inferior composta por lipídeos e clorofórmio e adicionado $1 \mathrm{~g}$ de sulfato de sódio anidro P.A. (Synth, São Paulo, Brasil), sendo filtrado em filtro de papel $\mathrm{n}$. 으 1 (125 mm $\varnothing$, Whatman). As amostras (8 mL) foram colocadas para secagem em estufa a $95^{\circ} \mathrm{C}$ por 6 horas.

\subsubsection{Proteínas}

A determinação de proteínas foi realizada pelo método de Dumas, no qual foram pesadas 25 gramas de cada uma das amostras, sendo estas submetidas à temperatura de $950^{\circ} \mathrm{C}$ até a combustão rápida em presença de oxigênio puro. $\mathrm{O}$ carbono da amostra foi convertido em dióxido de carbono $\left(\mathrm{CO}_{2}\right)$ e os subprodutos, nitrogênio e seus óxidos, foram carreados para um sistema de filtração termoelétrico para remoção do teor de umidade. Uma alíquota dos gases resultantes foi submetida a um sistema catalisador para remoção dos gases interferentes e o $\mathrm{N}_{2}$ foi quantificado por diferença de condutividade térmica ao gás hélio puro. O sistema, controlado por um software operacional do Windows, determinou a porcentagem de $\mathrm{N}_{2}$, convertido em conteúdo de proteína usando fator de conversão de 6,25. 


\subsubsection{Estabilidade físico-química dos embutidos}

As análises para avaliar a estabilidade físico-química (substâncias reativas ao ácido tiobarbitúrico - TBARS, $\mathrm{pH}$ e cor objetiva) da linguiça frescal foram realizadas nos dias 1, 4, 8, 11 e 15 dias e da mortadela nos dias 1, 14, 28, 42 e 56 a partir do dia do processamento, num total de cinco pontos de análise para cada embutido.

\subsubsection{Substâncias Reativas ao Ácido Tiobarbitúrico (TBARS)}

Para a realização das análises de TBARS foi utilizada a metodologia descrita por Hodges et al. (1999) indicada para avaliação da oxidação lipídica em materiais contendo compostos interferentes de cor, como é o caso das antocianinas. As análises foram realizadas em quadruplicata e $5 \mathrm{~g}$ de amostras foram homogeneizadas em $25 \mathrm{~mL}$ de solução contendo ácido tricloroacético (TCA) 7,5\%, propil galato (PG) 0,1\% e ácido etilenodiamino tetra-acético (EDTA) 0,1\% em equipamento ultra-turrax (TE 102, Tecnal, Brasil). Essa mistura foi filtrada em papel filtro $n . \stackrel{1}{1}$ (125 mm $\varnothing$, Whatman) e $5 \mathrm{~mL}$ foram adicionados com a mesma quantidade de solução de ácido tiobarbitúrico (TBA) sendo que para cada tratamento foram feitos dois tubos sem adição de TBA. Após 40 min em banho-maria ultratermostatizado (Marconi, Brasil) a 98ํㅡ, as leituras de absorbância foram feitas em espectrofotômetro (SP-22, Biospectro, Brasil) a 440, 532 e $600 \mathrm{~nm}$. Os valores de TBARS foram calculados a partir da fórmula descrita na eq. (3) e os resultados foram expressos como miligrama de malonaldeído (MDA) /quilograma de amostra.

$$
\begin{aligned}
& {[A 532+\mathrm{TBA}-\mathrm{A} 600+\mathrm{TBA}]-[\mathrm{A} 532-\mathrm{TBA}-\mathrm{A} 600-\mathrm{TBA}]=\mathrm{A}} \\
& (\mathrm{A} 440+\mathrm{TBA}-\mathrm{A} 600+\mathrm{TBA}) \cdot 0,0571=\mathrm{B} \\
& \mathrm{MDA}=\frac{(\underline{A-B}) \cdot 10^{6}}{157000}
\end{aligned}
$$

\subsubsection{Análise de $\mathrm{pH}$}

As medições de $\mathrm{pH}$ foram realizadas com a utilização de um pHmetro de perfuração (HI 99163, Hanna, Brasil) com eletrodo combinado para leitura em triplicata com perfuração de seis pontos diferentes nas amostras. 


\subsubsection{Cor objetiva}

As amostras de cada tratamento foram submetidas à avaliação de cor utilizandose um espectrofotômetro portátil (mod. MiniScan XE, marca HunterLab), através da escala $L^{*}, a^{*}, b^{*}$, do sistema CIE Lab, utilizando-se o iluminante D65, ângulo de observação de $10^{\circ}$ e abertura de célula com $30 \mathrm{~mm}$, para cálculo dos valores $L^{*}$, a* e $b^{*}$ médios de três leituras.

\subsubsection{Estabilidade microbiológica}

As análises para avaliar a estabilidade microbiológica da linguiça frescal foram realizadas nos dias 1, 4, 8, 11 e 15 dias e da mortadela nos dias 1, 14, 28, 42 e 56 dias a partir do dia do processamento, num total de cinco pontos de análise.

Todos os procedimentos de abertura de embalagens, pesagens e inoculação foram realizados em cabine de fluxo laminar, e todos os utensílios e equipamentos utilizados foram esterilizados em autoclave e limpos com álcool 70\% antes do uso. Foram retiradas $25 \mathrm{~g}$ das amostras (para pesagem utilizou-se saco plástico esterilizado Whirl-pak) e em seguida foram acrescentados $225 \mathrm{~mL}$ de água peptonada $(0,1 \%)$ obtendo-se a primeira diluição. Diluições seriadas foram feitas a partir de tubos de ensaio contendo $9 \mathrm{~mL}$ de água peptonada. Foram realizadas análises de contagem de microrganismos aeróbios e anaeróbios mesófilos e psicrotróficos, bactérias lácticas, clostrídios sulfito redutores, coliformes a $45^{\circ} \mathrm{C}$ Staphylococcus aureus e pesquisa de Salmonella sp.

\subsubsection{Mesófilos e Psicrotróficos aeróbios e anaeróbios}

$\mathrm{Na}$ determinação de mesófilos e psicrotróficos aeróbios e anaeróbios foi seguido o método oficial AOAC no 990.12, utilizando como meio de cultura as placas Petrifilm $^{\mathrm{TM}}$ (3M, Brasil). Para linguiça frescal foram inoculados $1 \mathrm{~mL}$ das diluições das amostras nas placas contendo o meio de cultura e após inoculação foram incubadas à $37 \pm 1^{\circ} \mathrm{C}$ por $48 \pm 2$ horas (DT $6150 \mathrm{C}$, Diagtech, Brasil) para os mesófilos aeróbios e à $7 \pm 1^{\circ} \mathrm{C}$ por 10 dias (MA415, Marconi, Brasil) para os psicrotróficos aeróbios. Para a mortadela foi inoculado $1 \mathrm{~mL}$ das diluições das amostras nas placas contendo o meio de cultura e após inoculação foram acondicionadas em jarros de anaerobiose (Probac, 
Brasil) incubados em estufa bacteriológica (DT $6150 \mathrm{C}$, Diagtech, Brasil) à $37 \pm 1^{\circ} \mathrm{C}$ por $48 \pm 2$ horas para os mesófilos anaeróbios e em B.O.D. (MA415, Marconi, Brasil) a $21 \pm 1^{\circ} \mathrm{C}$ por três dias para os psicrotróficos anaeróbios. Os resultados foram expressos em UFC g-1 de amostra (HORWITZ; LATIMER, 2007).

\subsubsection{Bactérias lácticas}

$\mathrm{Na}$ determinação das bactérias lácticas conforme descrito por Silva et al. (2010b), foram inoculados $1 \mathrm{~mL}$ das diluições das amostras em placas de petri estéreis descartáveis e adicionado o meio de cultura ágar MRS (De Man, Rogosa, Sharpe, Acumedia, Brasil) com plaqueamento em profundidade e sobrecamada do ágar para incubação em atmosfera normal para linguiça frescal. Para a mortadela após inoculação foram acondicionadas em jarros de anaerobiose (Probac, Brasil) e incubados em estufa bacteriológica (DT $6150 \mathrm{C}$, Diagtech, Brasil) a $37 \pm 1^{\circ} \mathrm{C}$ por $48 \pm 2$ horas. Os resultados foram expressos em UFC $\mathrm{g}^{-1}$ de amostra.

\subsubsection{Clostrídios sulfito redutores para mortadela}

A contagem de clostrídios sulfito redutores foi efetuada de acordo com Silva et al. (2010b), utilizando ágar Triptose Sulfito Cicloserina (TSC, Himedia, Brasil). Foi realizada a inoculação de $1 \mathrm{~mL}$ das diluições selecionadas na superfície das placas de Petri e em seguida estas alíquotas foram cobertas com uma sobrecamada de Ágar TSC suplementado com $0,1 \mathrm{~mL}$ de solução de cicloserina $4 \%$. Após a completa solidificação do ágar, as placas foram acondicionadas em jarros de anaerobiose (Probac, Brasil), sem inverter e incubados em estufa B.O.D. (MA415, Marconi, Brasil) a $45^{\circ} \pm 1^{\circ} \mathrm{C}$ por $24 \pm 2$ horas. Na presença de colônias a contagem seria expressa em UFC $\mathrm{g}^{-1}$ de amostra.

\subsubsection{Coliformes à $45 \circ \mathrm{C}$}

Na determinação de coliformes foi utilizado o método oficial AOAC № 998.08, utilizando como meio de cultura as placas Petrifilm ${ }^{\mathrm{TM}}$ ( $3 \mathrm{M}$, Brasil). Foram inoculados $1 \mathrm{~mL}$ da diluição das amostras e incubadas a $45 \pm 1^{\circ} \mathrm{C}$ por $24 \pm 2$ horas em B.O.D. 
umidificada (MA415, Marconi, Brasil). Todas as colônias presentes nas placas foram contadas. A contagem das colônias foi expressa em UFC g ${ }^{-1}$ de amostra.

\subsubsection{Staphylococcus aureus}

Para a sua determinação foi seguido o método oficial AOAC n 2003.11, utilizando como meio de cultura as placas Petrifilm ${ }^{\mathrm{TM}}$ Staph Express (3M, Brasil) incubadas a $37 \pm 1^{\circ} \mathrm{C}$ por $24 \pm 2$ horas (DT $6150 \mathrm{C}$, Diagtech, Brasil). Após este período foi observada a formação de colônias apenas vermelho-violetas nas placas, quando não havia crescimento destas colônias o teste era finalizado, porém, se houvesse crescimento de colônias mistas (vermelho-violetas, pretas e/ou azuis-esverdeadas) era necessário utilizar um disco de confirmação Petrifilm ${ }^{\mathrm{TM}}$ Staph Express (3M, Brasil), as placas eram então incubadas, novamente, por 1 a 3 horas na mesma temperatura citada anteriormente. Após este período, somente colônias com desenvolvimento de halos rosados deveriam ser contados e identificados como $S$. aureus. A contagem das colônias foi expressa em UFC g ${ }^{-1}$ de amostra.

\subsubsection{Salmonella sp.}

A análise de Salmonella sp. foi feita por meio do BAX ${ }^{\circledR}$ System da Dupont/Qualicon, baseado na automação das análises de alimentos por Reação de Polimerase em Cadeia (PCR), conforme método descrito por Kushida (2005). O "kit" completo possui todos os reagentes na forma de tabletes, que requer apenas um período de enriquecimento $\left(35^{\circ} \mathrm{C} / 18-24 \mathrm{~h}\right)$, seguida da lise e aplicação da PCR, que demanda quatro horas adicionais. O pré enriquecimento da amostra foi realizado em água peptonada $1 \%$ (diluição $10^{-1}$ ), sendo $25 \mathrm{~g}$ de amostra triturada para $225 \mathrm{~mL}$ de água peptonada, incubada a $37 \pm 1^{\circ} \mathrm{C}$ por $24 \pm 2$ horas (DT $6150 \mathrm{C}$, Diagtech, Brasil). Após esse período, foram transferidos $5 \mu \mathrm{L}$ de cada amostra para tubos contendo $200 \mu \mathrm{L}$ de tampão de lise, que foram fechados e colocados em banho-maria a $37^{\circ} \mathrm{C}$ por 20 minutos, posteriormente a 95으 por 10 minutos e em seguida transferidos para placa de gelo por 5 minutos no mínimo. Após este processo as amostras foram submetidas ao final da PCR. 


\subsubsection{Análise sensorial}

Para avaliar a aceitação sensorial de linguiça frescal foram recrutados 100 consumidores no dia posterior ao processamento, ou seja, a linguiça foi avaliada sensorialmente somente no dia seguinte ao processamento. Já para a mortadela foram recrutados 60 consumidores em cada intervalo de análise e os testes foram repetidos ao longo do tempo para avaliar a estabilidade sensorial durante a estocagem. Os consumidores eram graduandos, pós-graduandos, docentes e funcionários da FZEA/USP de Pirassununga/SP e o critério de seleção adotado foi a pessoa gostar e consumir linguiça suína e mortadela.

Os consumidores receberam e assinaram um termo de consentimento livre e esclarecido (Apêndice A) antes da realização das análises. O projeto de pesquisa foi submetido e aprovado pelo Comitê de Ética da Faculdade de Zootecnia e Engenharia de Alimentos, Universidade de São Paulo ( $\left.n^{\circ} 38313414.4 .0000 .5422\right)$.

Um teste afetivo de aceitação foi realizado usando uma escala hedônica de 9 pontos (escala variando de 1 -“detestei" a 9 -“adorei”) conforme método descrito por Meilgaard, Civille e Carr (2006). Para linguiça frescal as amostras foram assadas em forno elétrico à $200^{\circ} \mathrm{C}$ por aproximadamente 40 minutos, sendo viradas com o tempo de 20 minutos, suficiente para atingir $72^{\circ} \mathrm{C}$ internamente. As amostras foram cortadas em seis pedaços de $2 \times 2 \mathrm{~cm}$ e mantidas em estufa a $60^{\circ} \mathrm{C}$ e servidas monadicamente aos consumidores em pratos plásticos descartáveis codificados por números de três dígitos. Para mortadela as amostras foram fatiadas na espessura de três milímetros e servidas monadicamente duas fatias aos provadores em pratos plásticos descartáveis codificados por números de três dígitos. A análise foi realizada em cabines individuais, iluminadas por luz branca seguindo delineamento em blocos casualizados completos. Os atributos analisados foram cor, aroma, textura, sabor e qualidade global (Figura 10 e 11). 
Figura 10. Ficha utilizada para avaliação das amostras de linguiça frescal $(n=100)$.

\begin{tabular}{|c|c|c|c|}
\hline \multicolumn{4}{|c|}{$\begin{array}{l}\text { Nome: } \\
\text { Você está recebendo uma amostra de LINGUIÇA FRESCAL. Por favor, avalie o produto e marque na escala } \\
\text { o quanto você gostou ou desgostou das seguintes características: }\end{array}$} \\
\hline \multicolumn{2}{|c|}{ Número da amostra } & Nota & \\
\hline \multirow{5}{*}{$\begin{array}{l}\text { ESCALA } \\
\text { 1-Detestei } \\
\text { 2-Desgostei muito } \\
\text { 3-Desgostei } \\
\text { moderadamente } \\
\text { 4-Desgostei ligeiramente } \\
\text { 5-Nem gostei/nem desgostei } \\
\text { 6-Gostei ligeiramente } \\
\text { 7-Gostei moderadamente } \\
\text { 8-Gostei muito } \\
\text { 9-Adorei }\end{array}$} & COR & & Comentários: \\
\hline & AROMA & & Comentários: \\
\hline & TEXTURA & & Comentários: \\
\hline & SABOR & & Comentários: \\
\hline & $\begin{array}{l}\text { QUALIDADE } \\
\text { GLOBAL }\end{array}$ & & Comentários: \\
\hline
\end{tabular}

Fonte: Própria autoria.

Figura 11. Ficha utilizada para avaliação das amostras de mortadela $(n=60)$.

Nome:

Data:

Ficha

Você está recebendo uma amostra de MORTADELA. Por favor, avalie o produto e marque na escala $\circ$ quanto você gostou ou desgostou das seguintes características:

Número da amostra

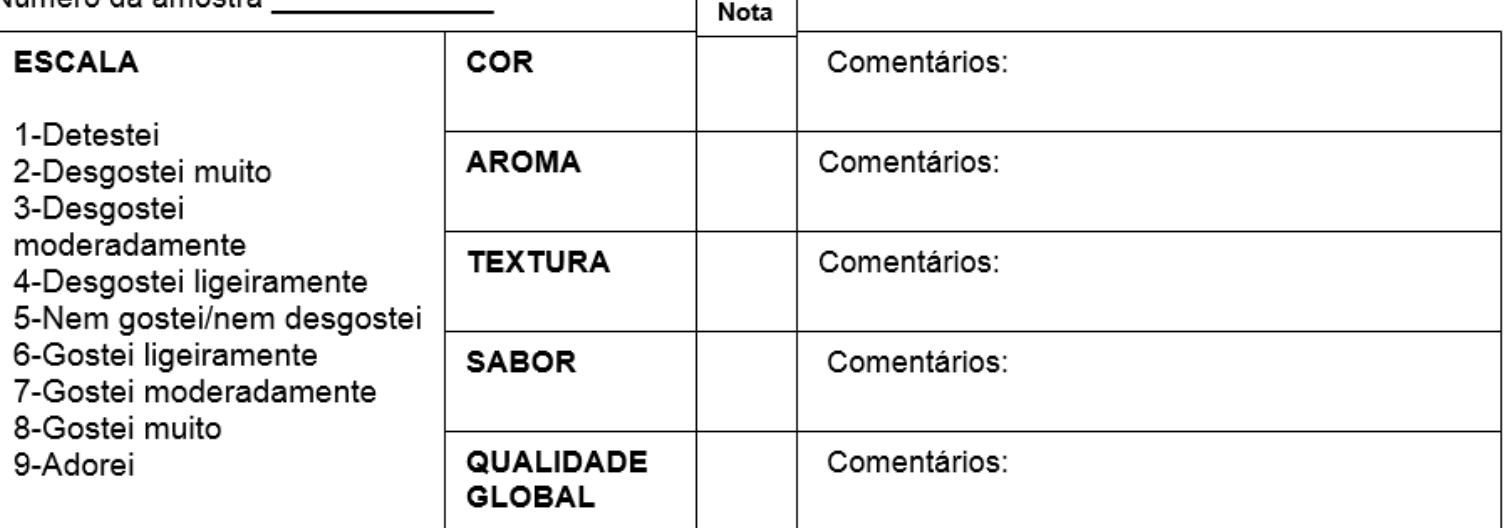

Fonte: Própria autoria.

\subsection{Análises estatísticas e delineamento experimental}

Utilizou-se um delineamento experimental casualizado em blocos, com quatro tratamentos de linguiça frescal (sem corante, carmim de cochonilha, jabuticaba $2 \%$ e jabuticaba 4\%) e três repetições dos processos com medidas repetidas no tempo em cinco ocasiões $(1,4,8,11$ e 15 dias) e com três tratamentos para a mortadela (sem 
corante, carmim de cochonilha e jabuticaba $2 \%$ ), em três repetições dos processos, com medidas repetidas no tempo em cinco ocasiões (1, 14, 28, 42 e 56 dias). A análise estatística das características físico-químicas avaliadas foi realizada utilizando-se o procedimento proc mixed do $S A S^{\circledR}$, versão 9.1.3. e utilizou-se o critério de Akaike (AIC) para escolher a melhor estrutura de covariâncias das respostas ao longo do tempo. As diferenças entre as médias dos grupos foram avaliadas pelo teste de Tukey ao nível de $5 \%$ de significância. A escolha do grau do polinômio usado para explicar o comportamento médio das respostas ao longo do tempo foi feita por meio de contrastes de polinômios ortogonais. As respostas experimentais, obtidas ao longo do tempo, para o estudo da estabilidade dos embutidos foram submetidas a ajustes de modelos de regressão linear e/ou quadrática para verificar as variações ocorridas durante a estocagem, complementando-se os resultados com tabelas e/ou gráficos.

\section{RESULTADOS E DISCUSSÃO}

\subsection{Caracterização e avaliação do potencial antioxidante e antimicrobiano do extrato aquoso e microencapsulado de jabuticaba}

\subsubsection{Valor de pH e teor de sólidos solúveis do extrato aquoso}

O extrato aquoso apresentou $\mathrm{pH}$ de $3,69 \pm 0,02$, considerado ácido, podendo representar benefícios para fins industriais, diminuindo alterações microbianas e prolongando a vida útil dos produtos. Este valor é próximo ao observado por Lima et al. (2008), que ao realizarem a caracterização química da jabuticaba variedade Paulista, obtiveram $\mathrm{pH}$ de 3,47 na casca da jabuticaba.

O teor de sólidos solúveis foi de 8,0Brix para o extrato aquoso de jabuticaba. No entanto, Lima et al. (2008) encontraram $12,40^{\circ}$ Brix para a casca da jabuticaba. A concentração desses sólidos constitui-se em uma das variáveis mais importantes para medir a qualidade dos frutos e seu grau de maturação, sendo que quanto maior esse valor mais amadurecido está o fruto. 


\subsubsection{Teor de antocianinas totais do extrato de jabuticaba aquoso e microencapsulado}

Em relação à quantidade de antocianinas totais do extrato microencapsulado obtido no presente trabalho, o valor encontrado foi de 7,21 $\pm 0,16 \mathrm{mg}$ equivalente cianidina-3-glicosídeo/g de extrato microencapsulado, valor superior ao encontrado no extrato aquoso, que foi de 5,95 $\pm 0,17 \mathrm{mg}$ equivalente cianidina-3-glicosídeo/g extrato aquoso. Este resultado é esperado, pois a microencapsulação tem a finalidade de proteger o material das condições adversas do meio, tais como luz, umidade, oxigênio e interações com outros compostos, estabilizando o produto e aumentando sua vida útil (SHAHIDI; HAN, 1993). Devido à concentração de sólidos no extrato microencapsulado, a quantidade de açúcar contido no extrato, juntamente com a quantidade de maltodextrina utilizada, apresentou três vezes mais sólidos no extrato seco. Reforça-se a utilização de extrato de jabuticaba microencapsulado, devido à proteção oferecida pelo material carreador, neste caso a maltodextrina, que torna estes alimentos menos vulneráveis à ação do tempo e, consequentemente, passíveis de armazenamento por longo período. Com isto, as indústrias podem optar por este produto devido à facilidade em transportá-lo e armazená-lo. O teor médio de antocianinas encontrado no extrato obtido do resíduo (cascas e sementes) da jabuticaba destaca a ampla presença destes compostos fenólicos. No trabalho de Abe, Lajolo e Genovese (2012), foram encontrados valores de 7,44 g/ equivalente ácido gálico/kg de casca de jabuticaba liofilizada extraída com metanol, água e ácido acético. Reynertson et al. (2008) verificaram valores de 2,78 mg de cianidina-3glicosídeo/g de peso seco em extrato de jabuticaba extraído com metanol.

Estas diferenças se devem à forma e ao tipo de solvente utilizado na extração das antocianinas, que no presente trabalho foi realizada com água destilada, sendo que os autores Reynertson et al. (2008) e Abe, Lajolo e Genovese (2012) utilizaram metanol e metanol acidificado. A justificativa da utilização da água como solvente se deve à utilização destes extratos em alimentos com a garantia de segurança aos consumidores (ALEZANDRO et al., 2013). 


\subsubsection{Análises do extrato de jabuticaba aquoso e microencapsulado por CLAE - MS e quantificação por CLAE - DAD}

A análise realizada por CLAE possibilitou a quantificação, com maior precisão do que no método espectrofotométrico, do teor de antocianinas presente no extrato de jabuticaba. A análise realizada por CLAE-MS permitiu a identificação das antocianinas presentes no extrato de jabuticaba (Tabela 3).

Tabela 3. Características cromatográficas e espectrométricas de antocianinas do extrato de jabuticaba obtidas por CLAE - MS.

\begin{tabular}{cccccc}
\hline Pico $^{a}$ & Antocianinas & $t_{R}(\min )$ & $\Lambda_{\operatorname{maxx}}(\mathrm{nm})$ & {$[\mathrm{M}]^{+}(\mathbf{m} / \mathbf{z})$} & $(\mathbf{m} / \mathbf{z})$ \\
\hline 1 & Delfinidina-3-glicosídeo & 9,19 & 525 & 465 & 303 \\
2 & Cianidina-3-glicosídeo & 9,56 & 517 & 449 & 287 \\
\hline
\end{tabular}

${ }^{a}$ Numerado de acordo com o cromatograma mostrado na Figura 12.

O perfil de antocianinas (cianidina-3-glicosídeo e delfinidina-3-glicosídeo) encontrado neste trabalho é semelhante aos encontrados na literatura para a fruta e a casca das variedades de jabuticaba Sabará e Paulista (SANTOS; VEGGI; MEIRELES, 2010; LIMA et al., 2011; ABE; LAJOLO; GENOVESE, 2012). De acordo com Lima et al. (2011), as antocianinas da jabuticaba estão mais concentradas na casca do fruto. Desta forma, a grande presença das antocianinas nas cascas do resíduo oriundo do processamento da fruta justifica sua utilização como compostos bioativos com atividades antioxidantes e antimicrobianas.

Na Figura 12 está apresentado o cromatograma obtido para o extrato estudado. $\mathrm{O}$ teor total de antocianinas foi de $1014 \mathrm{mg} / 100 \mathrm{~g}$ de extrato de jabuticaba aquoso. $\mathrm{O}$ pico 1 refere-se a delfinidina-3-glicosídeo ( $143 \mathrm{mg} / 100 \mathrm{~g}$ de extrato de jabuticaba) e o pico 2 a cianidina-3-glicosídeo ( $871 \mathrm{mg} / 100 \mathrm{~g}$ de extrato de jabuticaba). A cianidina-3glicosídeo (pico 2) foi a antocianina predominante, com $85,9 \%$ do total encontrado. 
Figura 12. Cromatograma do extrato de jabuticaba aquoso.

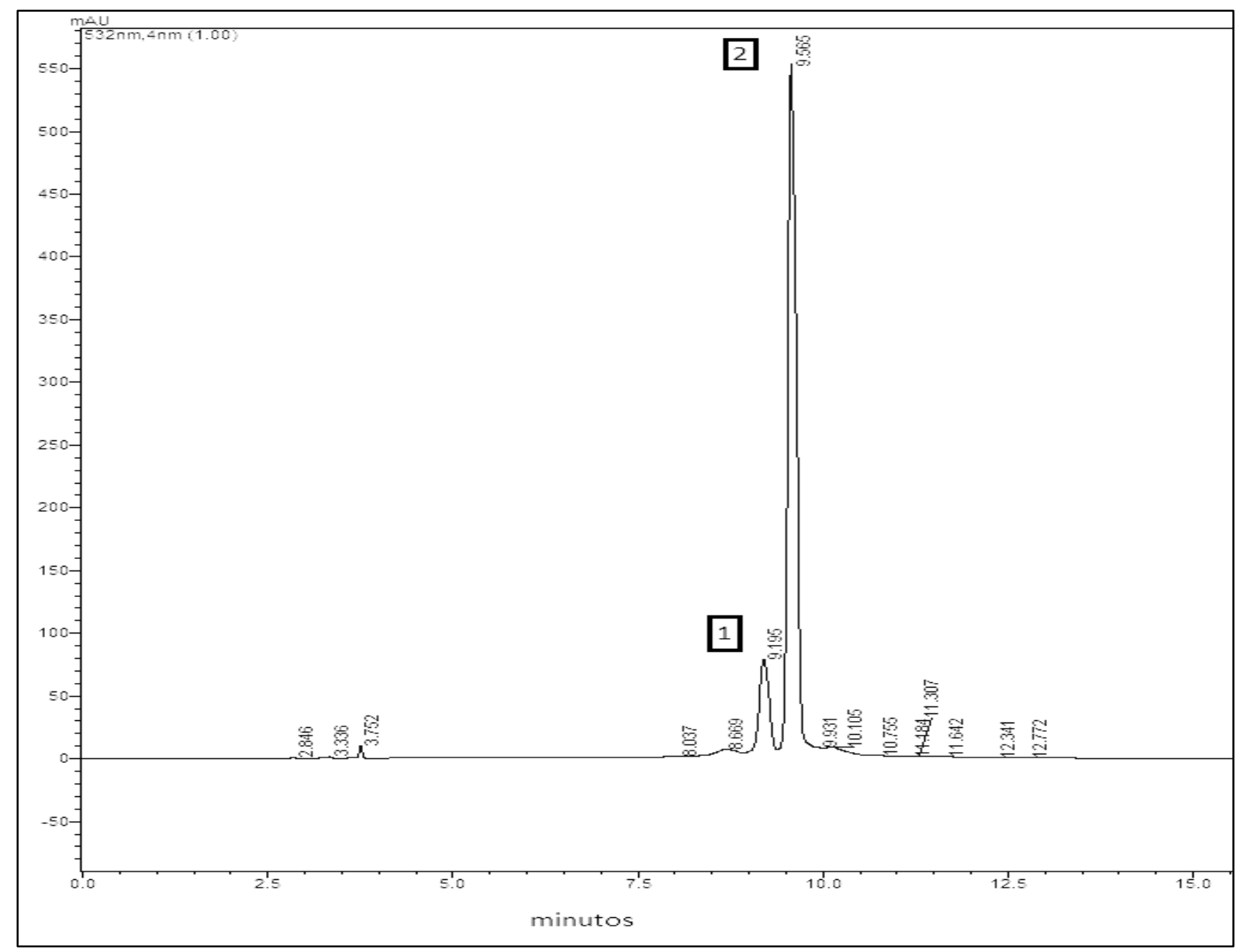

Condições cromatográficas: coluna C18, fase móvel, água ultrapura com ácido fosfórico e acetonitrila, volume de injeção $10 \mu \mathrm{L}$ e detecção em espectro de $530 \mathrm{~nm}$ para as antocianinas.

Foram identificados dois compostos, a cianidina-3-glicosídeo ( $871 \mathrm{mg} / 100 \mathrm{~g}$ ) e a delfinidina-3-glicosídeo (143 mg/100g) para o extrato aquoso e delfinidina-3glicosídeo (201 mg/100g) e cianidina-3-glicosídeo (1058 mg/100g) para o extrato microencapsulado. Este resultado é similar ao obtido por Lima et al. (2011), que encontraram as duas antocianinas na casca da jabuticaba das variedades Sabará e Paulista e por Leite-Legatti et al. (2012), que encontraram $75,6 \%$ de cianidina-3glicosídeo do total de antocianinas em casca de jabuticaba liofilizada.

\subsubsection{Conteúdo fenólico e Capacidade antioxidante in vitro do extrato de jabuticaba aquoso e microencapsulado}

O teor de compostos fenólicos no extrato aquoso da jabuticaba foi de $13,22 \pm 0,19 \mathrm{mg}$ equivalente ácido gálico/mL de extrato aquoso e 15,63 $\pm 0,20 \mathrm{mg}$ 
equivalente ácido gálico/g de extrato microencapsulado. O teor de compostos fenólicos no extrato de jabuticaba é extremamente variável. Silva et al. (2014) avaliaram o extrato de jabuticaba atomizado com maltodextrina em quatro variáveis dependentes e encontraram valores de 17,6 a 41,4 mg equivalente de catequina/g de extrato seco. Reynertson et al. (2008) estudaram a casca da jabuticaba extraída com metanol e liofilizada e encontraram valores de fenólicos totais de 31,6 mg equivalente ácido gálico/g de extrato seco. No trabalho de Abe, Lajolo e Genovese (2012) foram encontrados valores de 7,56 g equivalente ácido gálico/kg de casca de jabuticaba extraída com metanol acidificado e liofilizada.

A capacidade antioxidante para o método FRAP foi $5,76 \pm 0,08 \mu$ mol equivalente trolox/L de extrato aquoso e 20,51 $\pm 0,43 \mu \mathrm{mol}$ equivalente trolox/g de extrato microencapsulado. O método FRAP juntamente com outros métodos é um dos mais utilizados para a determinação da capacidade antioxidante in vitro. Recomenda-se que pelo menos dois ensaios combinados sejam realizados para uma maior fidelidade da capacidade antioxidante total de um produto (PÉREZ-JIMÉNEZ et al., 2008).

Para o DPPH o valor foi de $36,03 \pm 0,64 \mathrm{mmol}$ equivalente trolox/L de extrato aquoso e 52,90 $\pm 0,60 \mathrm{mmol}$ equivalente trolox/L de extrato microencapsulado. No trabalho de Abe et al. (2012) foram encontrados valores para DPPH de $62 \mathrm{mmol}$ equivalente trolox $/ \mathrm{kg}$ de casca de jabuticaba extraída com metanol acidificado e liofilizada.

As diferenças encontradas se justificam pela forma de extração, os solventes utilizados e o processo de secagem, que concentra os compostos do extrato e pode explicar o menor teor de compostos fenólicos encontrado no presente estudo em comparação com aqueles relatados por outros autores (ABE; LAJOLO; GENOVESE, 2012; LEITE-LEGATTI et al., 2012; ALEZANDRO et al., 2013; SILVA et al., 2014).

\subsubsection{Avaliação in vitro do potencial antimicrobiano do extrato de jabuticaba aquoso e microencapsulado}

Os resultados apresentados nas Tabelas 4 e 5 foram obtidos do extrato de jabuticaba aquoso e microencapsulado, após a realização dos ensaios de difusão em ágar. A zona de inibição para as bactérias Staphylococcus aureus ATCC 25923, Escherichia coli ATCC 25922 e Salmonella Enteritidis ATCC 13076 pode ser notada pela formação de halos (expresso em $\mathrm{mm}$ ) ao redor dos poços onde foram 
depositadas as concentrações de 10, 25, 50, 80 e 100\% do extrato de jabuticaba aquoso e 50,100,150, 200 e $300 \mathrm{mg} / \mathrm{mL}$ de extrato microencapsulado.

No extrato aquoso o menor halo, de $13 \mathrm{~mm}$, foi obtido na concentração de $10 \%$ para o Salmonella Enteritidis e o maior halo, de $25 \mathrm{~mm}$, foi observado na concentração de $100 \%$ para Staphylococcus aureus e Salmonella Enteritidis. No extrato microencapsulado o menor halo encontrado foi de $12 \mathrm{~mm}$ na concentração de 50 $\mathrm{mg} / \mathrm{mL}$ e o maior halo de $20 \mathrm{~mm}$ na concentração de 200 e $300 \mathrm{mg} / \mathrm{mL}$ para a Salmonella Enteritidis. Os menores halos observados são devido à utilização da maltodextrina como agente carreador, o qual diluiu o extrato e diminuiu sua eficácia.

Tabela 4. Potencial antimicrobiano do extrato de jabuticaba aquoso sobre os microrganismos testados.

\begin{tabular}{cccc}
\hline \multirow{2}{*}{$\begin{array}{c}\text { Concentração do } \\
\text { extrato (\%) }\end{array}$} & \multicolumn{3}{c}{ Zona de inibição (mm) } \\
\cline { 2 - 4 } & $\begin{array}{c}\text { Staphylococcus } \\
\text { aureus }\end{array}$ & $\begin{array}{c}\text { Escherichia } \\
\text { coli }\end{array}$ & $\begin{array}{c}\text { Salmonella } \\
\text { Enteritidis }\end{array}$ \\
\hline 10 & 16 & 15 & 13 \\
25 & 18 & 18 & 18 \\
50 & 21 & 20 & 20 \\
80 & 24 & 22 & 22 \\
100 & 25 & 25 & 23 \\
\hline
\end{tabular}

Silva et al. (2014) analisaram o extrato da casca de jabuticaba microencapsulado com maltodextrina e encontram zonas de inibição menores que os encontrados no presente estudo, variando de 9 a $12 \mathrm{~mm}$ de diâmetro para Staphylococcus aureus, 9,7 a 10,7 mm de diâmetro para Listeria monocytogenes e de 10,5 mm de diâmetro para Escherichia coli. Carvalho et al. (2009) analisaram as folhas da jabuticabeira e verificaram atividade inibitória sobre Streptococcus mutans, Streptococcus sobrinus e Streptococcus sanguinis, com a formação de halos variando de 12 a 16 mm de diâmetro, evidenciando o potencial antimicrobiano desta planta.

Macedo-Costa et al. (2009) avaliaram a eficácia do extrato das folhas de jabuticabeira sobre bactérias orais do gênero Streptococcus, sendo que os resultados encontrados foram halos de inibição variando de 10 a $18 \mathrm{~mm}$ de diâmetro. Os autores concluíram que o extrato das folhas de jabuticabeira produziu uma significativa atividade bacteriostática in vitro sobre as bactérias do biofilme dental.

De acordo com Lacombe et al. (2010), Côté et al. (2011) e Silva et al. (2013), o potencial antimicrobiano de extratos naturais é oriundo dos compostos fenólicos, 
teores de açúcar e ácidos orgânicos. De fato, no presente trabalho observou-se que os halos de inibição foram maiores quanto maior foi a concentração do extrato utilizado.

Tabela 5. Potencial antimicrobiano do extrato de jabuticaba microencapsulado sobre os microrganismos testados.

\begin{tabular}{cccc}
\hline \multirow{2}{*}{$\begin{array}{c}\text { Concentração do } \\
\text { extrato }(\mathbf{m g} / \mathbf{m L})\end{array}$} & \multicolumn{3}{c}{ Zona de inibição (mm) } \\
\cline { 2 - 4 } & $\begin{array}{c}\text { Staphylococcus } \\
\text { aureus }\end{array}$ & $\begin{array}{c}\text { Escherichia } \\
\text { coli }\end{array}$ & $\begin{array}{c}\text { Salmonella } \\
\text { Enteritidis }\end{array}$ \\
\hline 50 & 0 & 13 & 12 \\
100 & 14 & 14 & 14 \\
150 & 15 & 15 & 17 \\
200 & 17 & 15 & 20 \\
300 & 18 & 15 & 20 \\
\hline
\end{tabular}

Destaca-se no presente estudo, que os extratos aquoso e microencapsulado do resíduo da jabuticaba apresentaram efeito inibitório sobre bactérias gram positivas e gram negativas. Contrariamente ao observado por Michelin et al. (2005) que, testando extrato seco da casca da romã na concentração de 100 mg/mL, observaram a inibição somente de bactérias gram negativas.

Os resultados acima evidenciaram que o extrato microencapsulado teve formação de halos menores que o extrato aquoso. Isto se justifica pela quantidade de maltodextrina utilizada como material carreador, sendo que neste caso o extrato aquoso apresentou melhor desempenho devido a utilização sem diluição.

Os resultados obtidos para CIM do extrato de jabuticaba aquoso foi 9,37 g/L para S. aureus ATCC 25923, 18,75 g/L para E. coli ATCC 25922 e para S. Enteritidis ATCC 13076. Para o extrato microencapsulado a CIM foram 18,75 g/L para os três microrganismos testados. O extrato de jabuticaba apresentou resultados positivos no teste para CIM, apresentando assim ação bacteriostática, porém ao serem testados para a CBM, nenhum dos microrganismos testados foram inibidos.

Os resultados encontrados podem ser atribuídos ao fato de que o extrato de jabuticaba possui uma grande concentração de compostos fenólicos (antocianinas), os quais são os principais responsáveis pela atividade antimicrobiana (CAILLET et al., 2012). De acordo com Lima et al. (2011), Abe, Lajolo e Genovese (2012) e LeiteLegatti et al. (2012) as antocianinas da jabuticaba estão mais concentradas na casca da fruta. 
Silva et al. (2014) utilizaram extrato de jabuticaba microencapsulado e observaram valores de CIM próximos para $S$. aureus, variando de 12,5 a $25 \mathrm{~g} / \mathrm{L}$, para E. coli de $25 \mathrm{~g} / \mathrm{L}$ e $12,5 \mathrm{~g} / \mathrm{L}$ para Listeria monocytogenes. Michelin et al. (2005) ao analisarem o extrato seco da casca da romã observaram CIM entre 25 e $40 \mathrm{mg} / \mathrm{mL}$ apenas para as cepas gram negativas $E$. coli e $P$. aeruginosa.

Martin et al. (2012) observaram valores mais elevados e semelhantes aos relatados no presente estudo quando testaram extratos etanólicos e metanólicos obtidos a partir de resíduos vegetais. Esses autores obtiveram CIM e CBM de 6,2 g/L para o extrato metanólico da polpa de uvas Pinot Noir contra S. aureus. O CIM e CBM contra Listeria monocytogenes foi de $12,5 \mathrm{~g} / \mathrm{L}$ para o mesmo extrato. Estes autores também relataram valores de CIM e CBM de 12,5 e $25 \mathrm{~g} / \mathrm{L}$, respectivamente, para o extrato metanólico de resíduo de uva Petit Verdot contra Listeria monocytogenes.

No presente estudo, no qual foram evidenciados os menores valores de CIM para todas as bactérias, gram positivas e gram negativas, reforça a ideia da utilização do extrato da casca de jabuticaba com potencial antimicrobiano.

Como o resultado para CIM foi de $18,75 \mathrm{~g} / \mathrm{L}$ de extrato de jabuticaba microencapsulado (EJM), concluiu-se que a menor concentração que deveria ser utilizada na linguiça frescal e na mortadela seria até 18,75 gramas por quilo. Assim, optou-se por fazer um arredondamento deste resultado e utilizar, no mínimo, 20 gramas de EJM por quilo (2\%) de embutido cárneo.

\subsection{Aplicação do extrato de jabuticaba microencapsulado em linguiça frescal}

\subsubsection{Composição centesimal da linguiça frescal}

Os resultados para a composição centesimal da linguiça frescal nas três repetições realizadas estão apresentados na Tabela 6 . Não houve diferença $(p>0,05)$ entre os tratamentos e os resultados apresentados estão de acordo com o preconizado pela legislação brasileira com máximo de 70\% para umidade, mínimo de 12\% para proteína e máximo de 30\% para lipídeos (BRASIL, 2000). 
Tabela 6. Composição centesimal (\%) das amostras de linguiça frescal.

\begin{tabular}{ccccc}
\hline Linguiça frescal & Umidade & Proteína & Lipídeos & Cinzas \\
\hline Controle & $59,22 \pm 1,79^{\mathrm{a}}$ & $16,33 \pm 1,09^{\mathrm{a}}$ & $17,70 \pm 0,57^{\mathrm{a}}$ & $2,91 \pm 0,12^{\mathrm{a}}$ \\
Carmim de Cochonilha & $59,33 \pm 2,22^{\mathrm{a}}$ & $17,09 \pm 1,41^{\mathrm{a}}$ & $18,06 \pm 0,32^{\mathrm{a}}$ & $2,88 \pm 0,05^{\mathrm{a}}$ \\
Jabuticaba 2\% & $58,59 \pm 2,10^{\mathrm{a}}$ & $14,40 \pm 1,46^{\mathrm{a}}$ & $17,91 \pm 0,77^{\mathrm{a}}$ & $2,83 \pm 0,02^{\mathrm{a}}$ \\
Jabuticaba 4\% & $56,40 \pm 2,08^{\mathrm{a}}$ & $15,20 \pm 0,91^{\mathrm{a}}$ & $18,30 \pm 1,22^{\mathrm{a}}$ & $2,88 \pm 0,03^{\mathrm{a}}$ \\
\hline
\end{tabular}

Controle: linguiça frescal sem adição de corante, Carmim de cochonilha: linguiça frescal com corante tradicional carmim de cochonilha, Jabuticaba $2 \%$ : linguiça frescal com adição de $2 \%$ de EJM, Jabuticaba 4\%: linguiça frescal com adição de 4\% de EJM.

Resultados expressos pela média \pm erro padrão. Letras minúsculas diferentes numa mesma coluna indicam diferenças significativas $(p<0,05)$ entre os tratamentos.

\subsubsection{Estabilidade físico-química}

Em relação à oxidação lipídica da linguiça frescal armazenada sob refrigeração, avaliada por meio do índice de TBARS ( $\mathrm{mg}$ de malonaldeído/kg de amostra), observou-se que a oxidação dos tratamentos foi diferente $(p<0,05)$, variando ao longo do armazenamento refrigerado $(p<0,05)$ entre os tratamentos. Ao realizar-se 0 desdobramento da interação verificou-se que os resultados de TBARS não variaram $(p>0,05)$ entre as linguiças com os 2 diferentes níveis de EJM (2 e 4\%) ao longo do período de estocagem. O comportamento de ambos pode ser explicado por um modelo linear $(p<0,05)$ com leve inclinação negativa (modelos ajustados), conforme apresentado na Figura 13. Este resultado demonstra a eficiência do extrato de jabuticaba microencapsulado nas duas concentrações testadas para a inibição da oxidação lipídica na linguiça frescal.

De maneira similar, os índices de TBARS nos tratamentos Sem Corante e Carmim de Cochonilha não diferiram $(p>0,05)$, mas a oxidação aumentou $(p<0,05)$ linearmente ao longo do tempo.

De acordo com os resultados obtidos, é possível sugerir que as antocianinas presentes no EJM foram efetivas contra a produção de malonaldeído e pode ser indicado como antioxidante natural na formulação da linguiça frescal. 
Figura 13. Índice de TBARS ao longo da estocagem refrigerada da linguiça frescal.

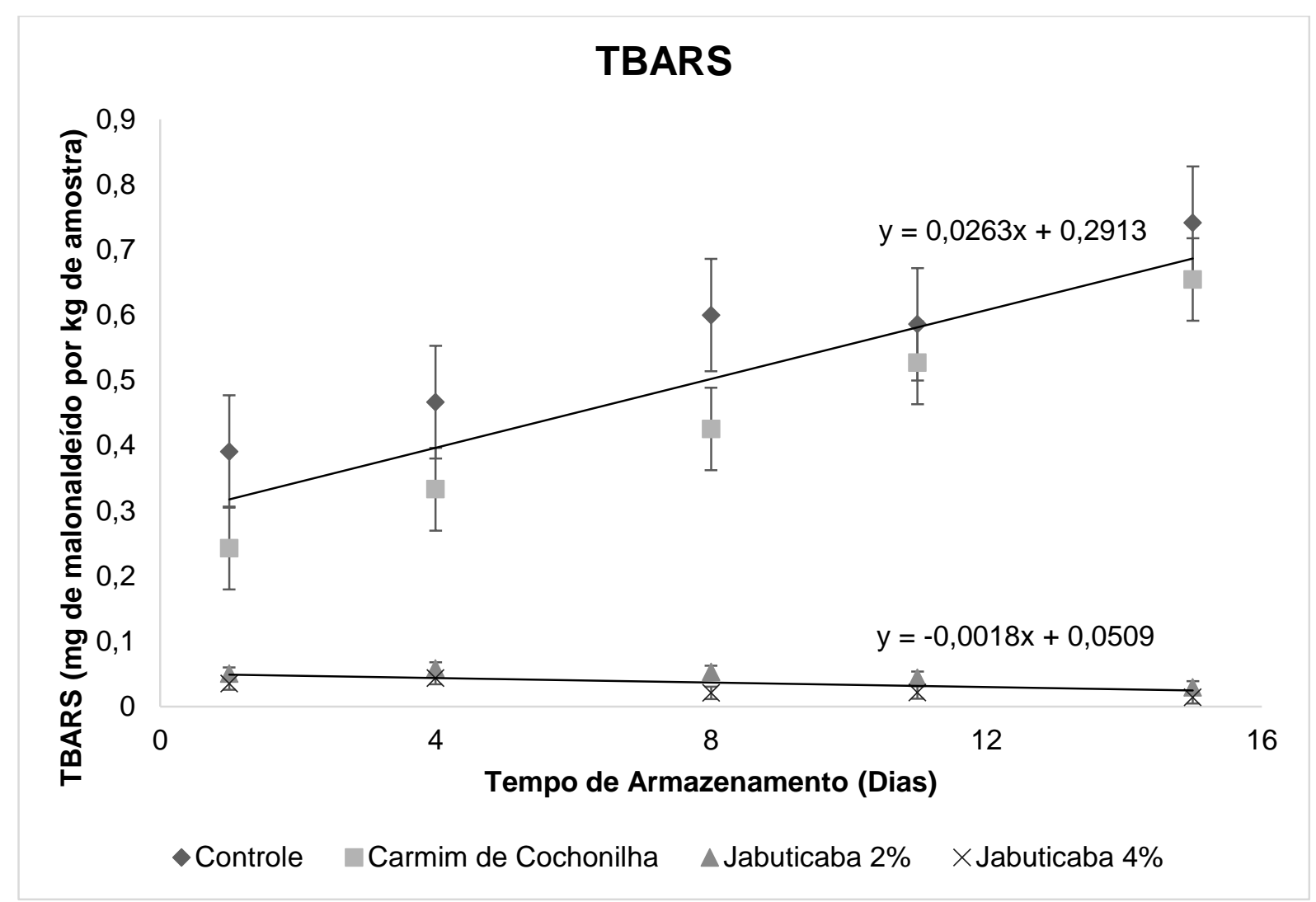

Almeida et al. (2015) adicionaram extrato etanólico de casca de jabuticaba liofilizado nas concentrações zero (controle), 0,25, 0,5, 0,75 e 1,0\% em mortadela tipo bologna, armazenadas sob refrigeração por 35 dias. Os autores encontraram valores de TBARS mais elevados (aproximadamente $0,3 \mathrm{mg}$ de MDA $/ \mathrm{kg}$ de amostra nos tratamentos com 0,5, 0,75 e 1,0\% de extrato de jabuticaba) que aqueles encontrados nas amostras com EJM (2 e 4\%) do presente estudo, enquanto que nas amostras controle e $0,25 \%$ eles verificaram $0,5 \mathrm{mg}$ de MDA $/ \mathrm{kg}$ de amostra, similares aos resultados encontrados no tratamento controle deste estudo.

Vale ressaltar que as condições de obtenção do extrato de jabuticaba foram muito diferentes no trabalho de Almeida et al. (2015), que realizaram a extração com etanol e desidratação do extrato por liofilização, enquanto no presente estudo foi realizada extração aquosa e secagem por spray dryer.

Os dados do presente estudo se assemelham aos encontrados por outros autores em diversos produtos cárneos adicionados de extratos naturais (SALEM; IBRAHIM, 2010; JAYAWARDANA et al., 2011; PHAM et al., 2014; QI et al., 2015; STEFANELLO et al., 2015). 
Os valores de pH estão apresentados na Figura 14. Verificou-se que houve diferença entre os tratamentos $(p<0,05)$ ao longo do tempo de armazenamento $(p<0,05)$ e interação entre tratamentos $x$ tempo de armazenamento $(p<0,05)$. Nas linguiças sem corante e com corante carmim de cochonilha, os valores de $\mathrm{pH}$ apresentaram comportamento semelhante $(p>0,05)$, que pode ser explicado por um modelo linear $(p<0,05)$ com um ligeiro aumento ao longo dos 15 dias de armazenamento refrigerado. Da mesma forma, os tratamentos com adição de 2 e $4 \%$ de EJM não diferiram entre si $(p>0,05)$, mas apresentaram redução do valor de $\mathrm{pH}$ ao longo do tempo de armazenamento, que também pode ser explicada por um modelo linear $(p<0,05)$.

A redução no valor de $\mathrm{pH}$ das linguiças frescais com adição do EJM foi, provavelmente, devida à maior presença de carboidratos (maltodextrina) nestes tratamentos, a qual pode ter causado a produção de ácido láctico por microrganismos que proliferaram nas linguiças. No estudo de Salem e Ibrahim (2010), a adição de extrato de óleo de sálvia em embutidos de carne de búfalo diminuiu o $\mathrm{pH}$ dos embutidos de 6,9 para 4,5 nos primeiros dois dias de armazenamento. De acordo com os autores, a produção de ácidos orgânicos pelas bactérias pode ter sido a causa da diminuição observada.

No trabalho de Almeida et al. (2015), os valores de $\mathrm{pH}$ encontrados em mortadela tipo bologna com extrato etanólico de casca de jabuticaba liofilizado variaram de 6,1 a 5,9 em todos os tratamentos nos 35 dias de armazenamento, concluindo que a diminuição do $\mathrm{pH}$ ocorreu pela alta acidez do extrato, mas os valores foram considerados normais para este embutido. 
Figura 14. Valores de $\mathrm{pH}$ ao longo da estocagem refrigerada da linguiça frescal.

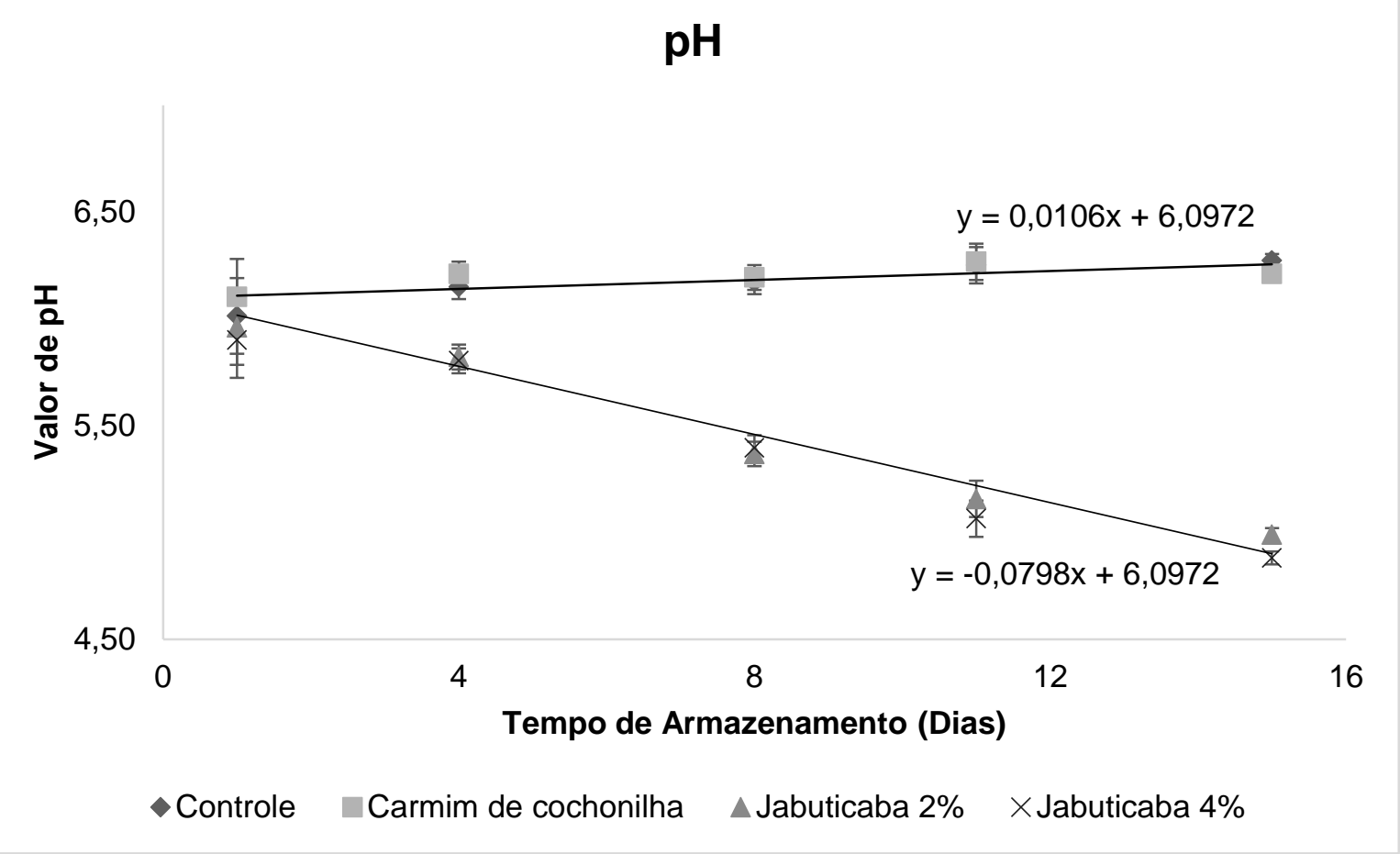

A análise de cor parâmetro $L^{*}$ demonstrou que houve diferenças entre os tratamentos $(p<0,05)$ e ao longo do tempo $(p<0,05)$, mas não houve interação tempo $x$ tratamento $(p>0,05)$. Os tratamentos com EJM apresentaram valores menores do que o controle, devido à adição do extrato. O tratamento com carmim de cochonilha apresentou menor valor de $L^{*}$ do que o tratamento com $4 \%$ de $E J M$, mas não foi diferente $(p>0,05)$ do $2 \%$ de EJM, indicando que a cor do tratamento com $2 \%$ de EJM não era mais escura do que a do tratamento carmim de cochonilha. Este comportamento pode ser explicado por um modelo linear com uma ligeira queda $(p<0,05)$ ao longo do tempo, o que pode ser verificado na Figura 15. 
Figura 15. Valores de $L^{*}$ ao longo da estocagem refrigerada da linguiça frescal.

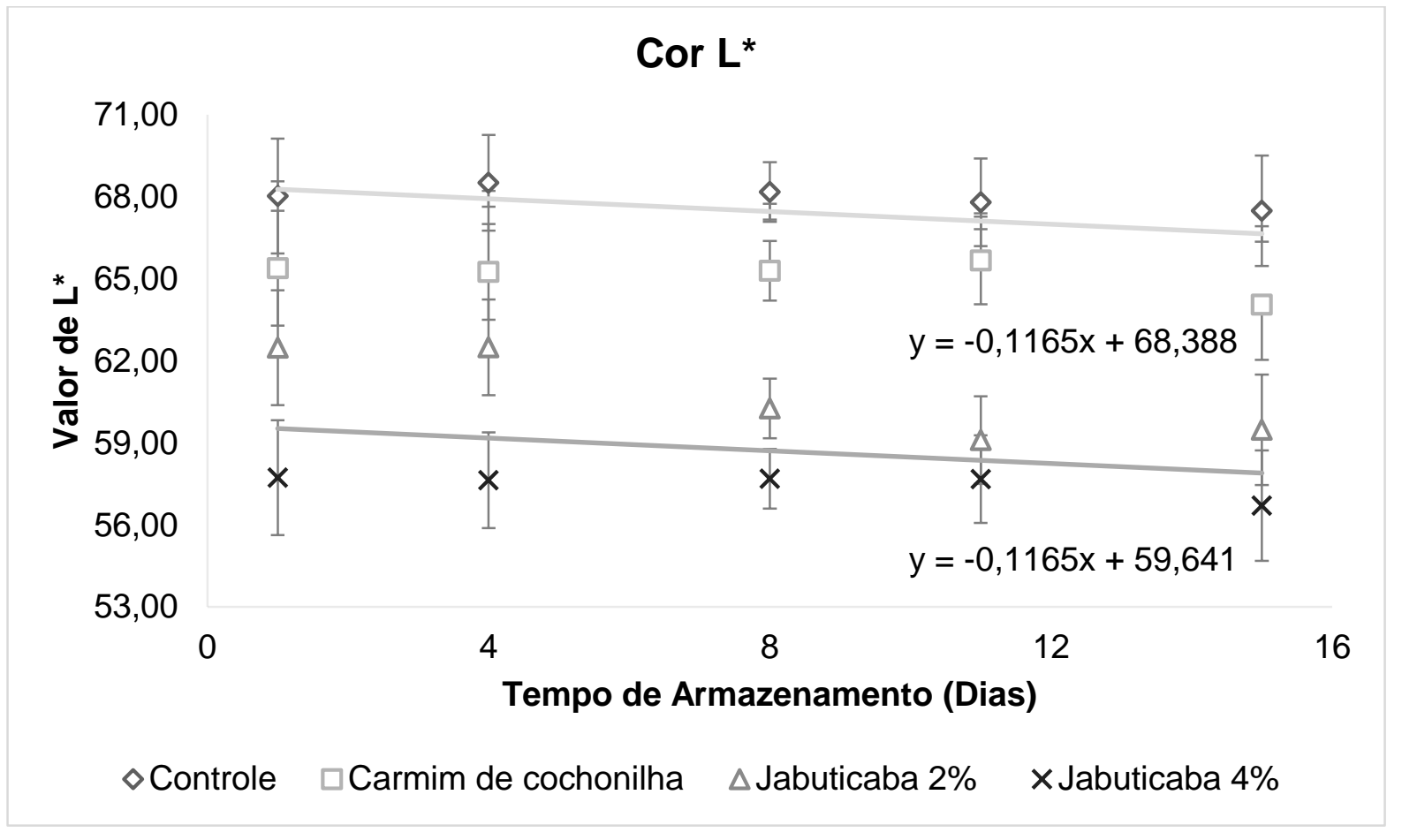

Os resultados para o parâmetro $a^{*}$ estão apresentados na Figura 16. Todos os tratamentos diferiram entre si $(p<0,05)$ e variaram ao longo do tempo $(p<0,05)$. No entanto, não tiveram interação tempo $x$ tratamento $(p>0,05)$, sendo que todos os tratamentos apresentaram comportamento semelhante de decréscimo do valor de $\mathrm{a}^{*}$, explicado por modelos quadráticos $(p<0,05)$. As linguiças avaliadas, com e sem extrato de jabuticaba, estão apresentadas na Figura 17. 
Figura 16. Valores de $a^{*}$ ao longo da estocagem refrigerada da linguiça frescal.

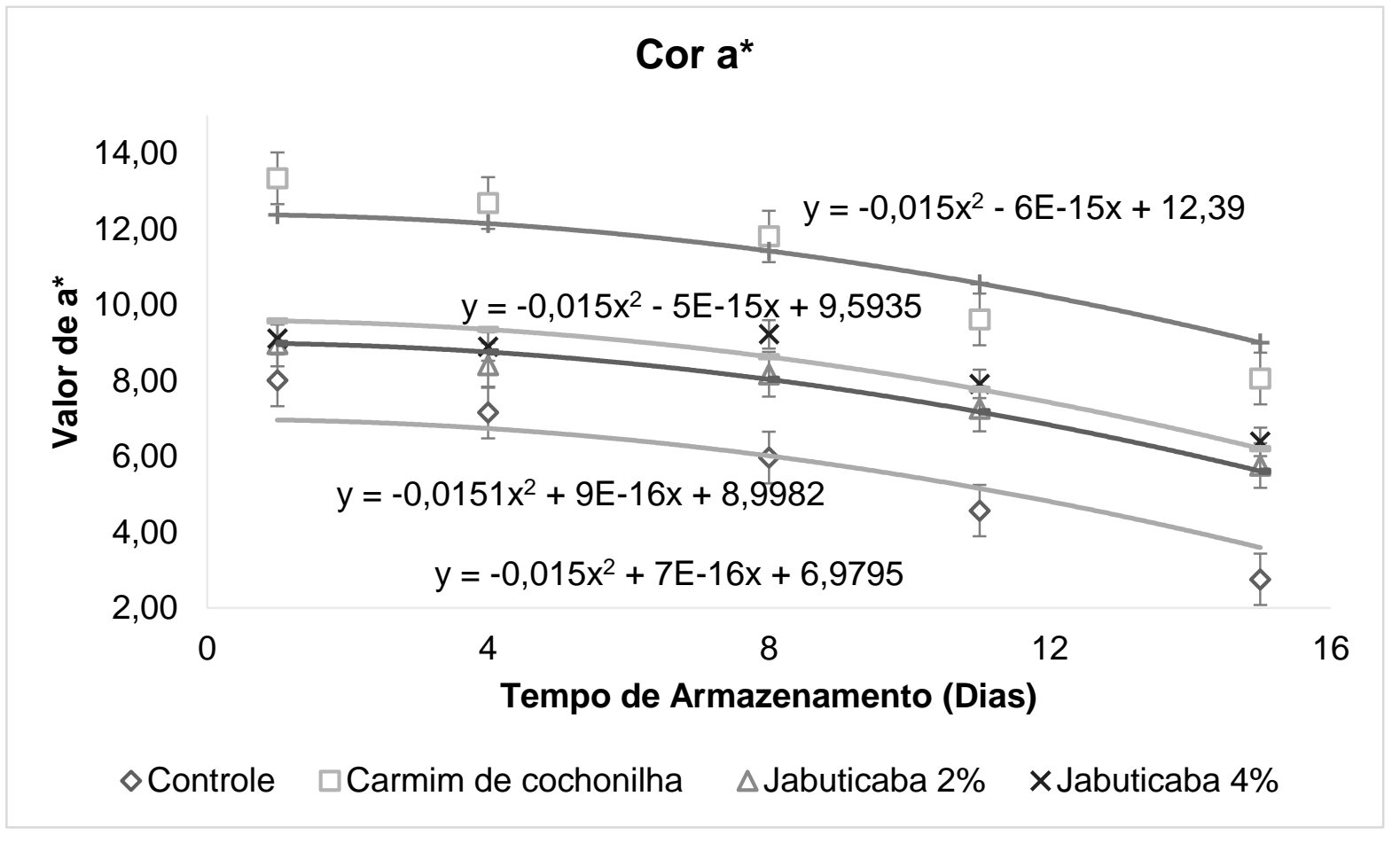

Figura 17: Tratamentos de linguiça frescal.

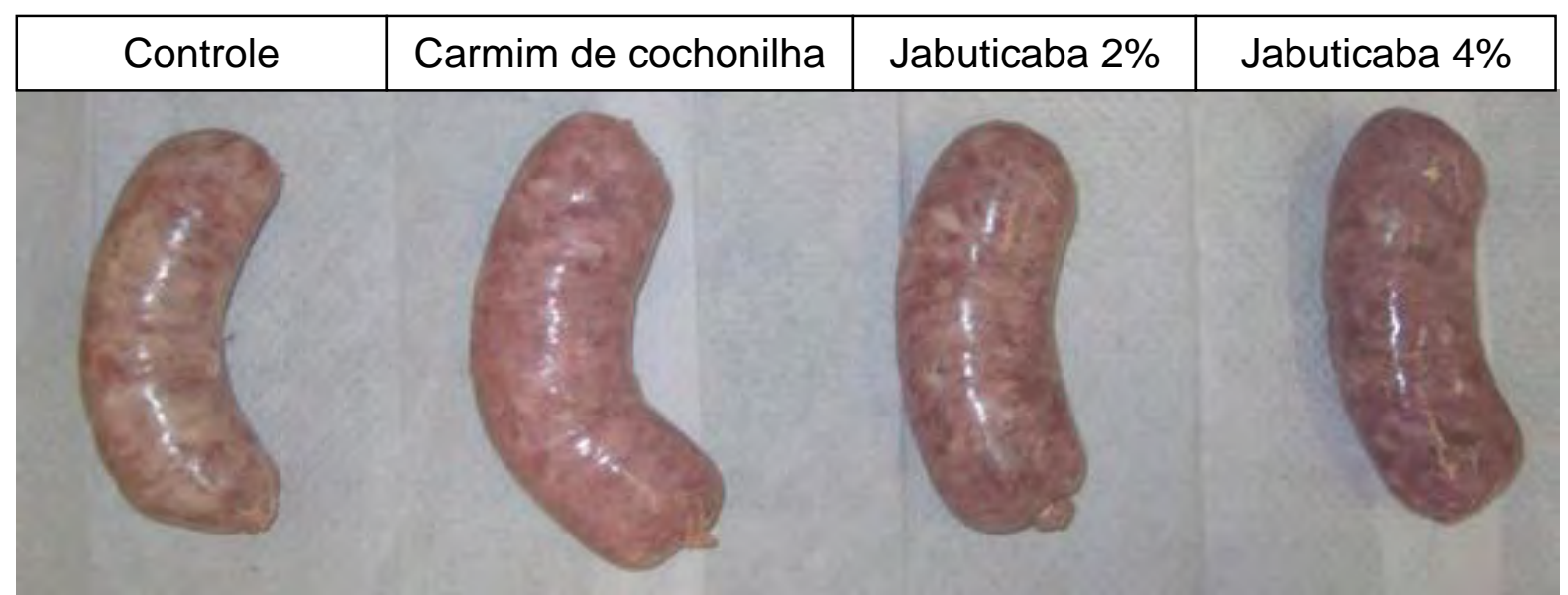

Controle: Linguiça frescal sem adição de corante; Carmim de cochonilha: linguiça frescal com corante tradicional carmim de cochonilha; Jabuticaba $2 \%$ : linguiça frescal com adição de $2 \%$ de EJM; Jabuticaba 4\%: linguiça frescal com adição de 4\% de EJM.

Embora a linguiça frescal com carmim de cochonilha tenha apresentado maior valor de $a^{*}$ (intensidade do vermelho) $(p<0,05)$ do que outros tratamentos, observouse que o tratamento com $4 \%$ de EJM teve um valor de $a^{*}$ maior que $2 \%$ de EJM e os tratamentos com EJM apresentaram valores de $\mathrm{a}^{*}$ superiores ao controle. Devido a este resultado, esperou-se que os maiores valores de $a^{*}$ das linguiças com EJM nas 
duas concentrações representaria uma melhor aceitação sensorial da cor que o tratamento controle, porém não ocorreu. Isto pode ser devido ao baixo valor de $L^{*} e$ $\mathrm{b}^{*} \mathrm{e}$ a cor mais roxa destes tratamentos. De acordo com Barros e Stringheta (2006), a cor influencia decisivamente a preferência dos consumidores na compra de alimentos, e o impacto visual causado pela cor geralmente se sobrepõe ao impacto causado por outros atributos.

Para os resultados da cor objetiva parâmetro $b^{*}$ (teor de amarelo), todos os tratamentos diferiram entre si $(p<0,05)$ e ao longo tempo $(p<0,05)$, mas não tiveram interação tempo $x$ tratamento $(p>0,05)$. Ou seja, todos os tratamentos apresentaram decréscimo do valor de $b^{*}$ durante o período de armazenamento, sendo que esse comportamento pode ser explicado por um polinômio de $2^{\circ}$ grau, conforme apresentado na Figura 18, demonstrado com uma tendência de queda do valor de $b^{*}$ ao longo do tempo.

Figura 18. Valores de $b^{*}$ ao longo da estocagem refrigerada da linguiça frescal.

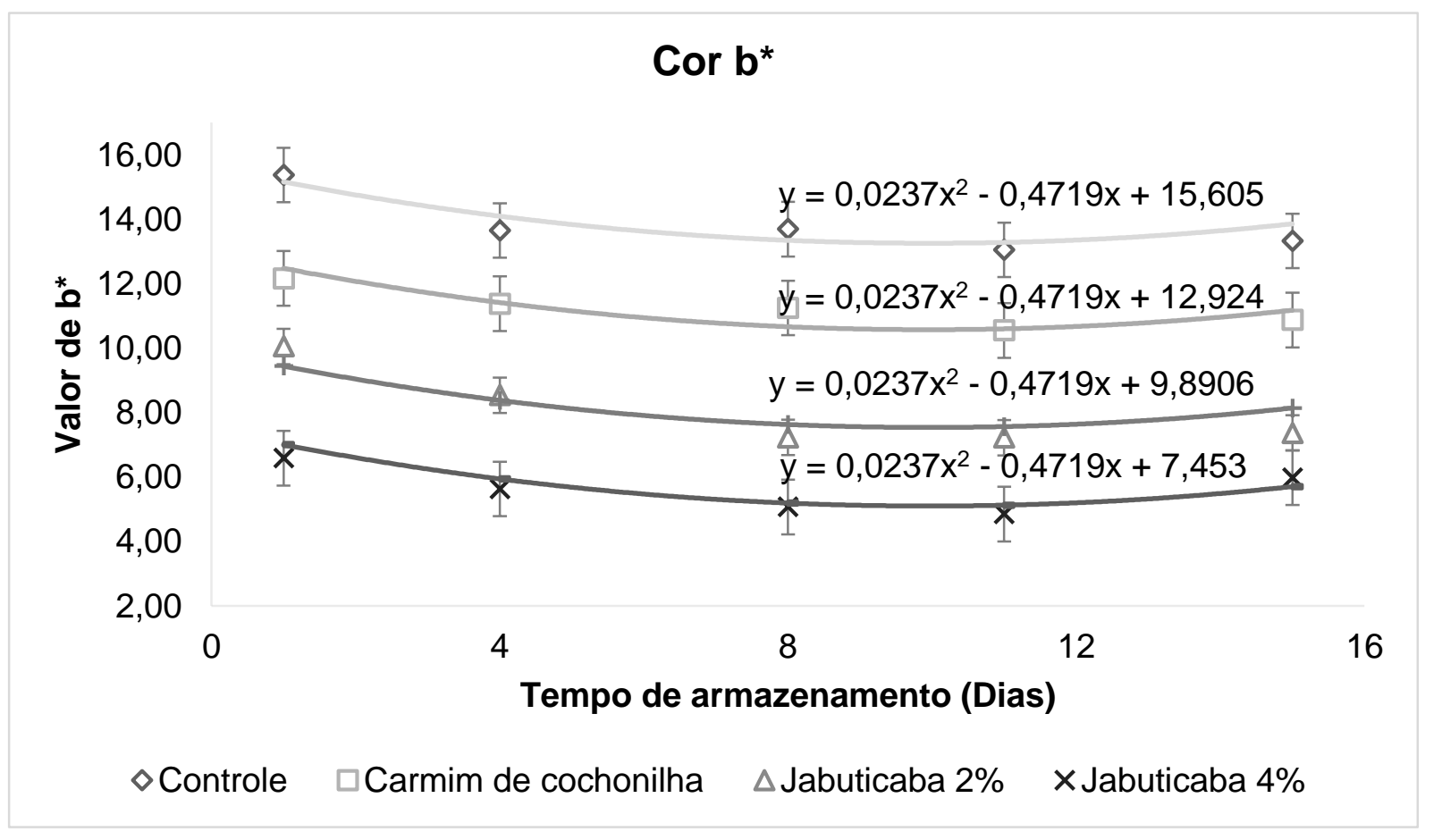

Almeida et al. (2015) verificaram que as concentrações 0,25 e $0,5 \%$ de extrato etanólico de casca de jabuticaba liofilizado em mortadela tipo bologna não afetaram os valores de $L^{*}$ e $b^{*}$, porém a adição de 0,75 e 1\% diminuíram valores de $a^{*}$. Os autores concluíram que apesar destas diferenças observadas em cor instrumental, na 
avaliação visual da cor não foi detectada diferença entre os tratamentos em relação ao controle.

Pham et al. (2014) verificaram que a adição de extrato de alecrim em linguiça suína fresca aumentou os valores de $b^{*}$ (amarelamento) em 0 a 3 meses de armazenamento. Os efeitos sinérgicos de alecrim e extrato de chá verde sobre $L^{*}$ (luminosidade), $a^{*}$ (vermelhidão) e $b^{*}$ foram significativos ao final de seis meses de armazenamento, já que concentrações mais altas de ambos os extratos destas plantas obtiveram aumento de vermelhidão, amarelamento e redução de claridade.

\subsubsection{Estabilidade microbiológica}

As contagens para coliformes a $45^{\circ} \mathrm{C}$, Staphylococcus aureus, mesófilos e psicrotróficos aeróbios e bactérias lácticas estão apresentados na Tabela 7. Com relação às análises microbiológicas para os coliformes a $45^{\circ} \mathrm{C}$, realizadas no $1^{\circ} \mathrm{e}$ último dia de armazenamento (15 dias), pode-se verificar principalmente a redução das contagens para os tratamentos com extrato de jabuticaba 2 e 4\%, destacando a eficiência do extrato de jabuticaba. De acordo com a legislação brasileira (BRASIL, 2001), o limite para estes microrganismos é de $5 \times 10^{3}$ UFC g ${ }^{-1}$ e os resultados obtidos no presente estudo foram abaixo desse valor em todas as amostras avaliadas. Almeida et al. (2015), ao analisarem mortadela tipo bologna com extrato etanólico de casca de jabuticaba liofilizado não detectaram a presença de coliformes termotolerantes nos 35 dias de armazenamento, o que pode ser devido ao produto ser um embutido cozido e atingir a temperatura de pasteurização.

Quanto aos testes microbiológicos para Staphylococcus aureus (Tabela 7), também realizados no $1^{\circ}$ e último dia de armazenamento, as linguiças com $2 \%$ e $4 \%$ de EJM apresentaram uma menor contagem de microrganismos quando comparado aos outros tratamentos. Após 15 dias de armazenamento, o tratamento com $2 \%$ de EJM não foi eficiente na redução de $S$. aureus em linguiça frescal, mas o tratamento com 4\% de EJM causou a eliminação desta bactéria, confirmando a eficiência do extrato de jabuticaba. Assim como para coliformes, o $S$. aureus apresentou valores abaixo do máximo recomendado pela legislação brasileira (BRASIL, 2001), a qual estabelece limite de $5 \times 10^{3} \mathrm{UFC} \mathrm{g}^{-1}$.

Para as contagens de bactérias mesófilas aeróbias verificou-se que os tratamentos com $2 \%$ e $4 \%$ de EJM apresentaram contagens próximas de 4,0 log UFC 
$\mathrm{g}^{-1}$, enquanto os tratamentos sem corante e com carmim de cochonilha, apresentaram contagens próximas de 4,5 log UFC g ${ }^{-1}$. Almeida et al. (2015) relataram valores abaixo de $4 \log$ UFC g ${ }^{-1}$ em mortadela tipo bologna adicionada com extrato etanólico da casca de jabuticaba liofilizada no início do armazenamento e 5,5 log UFC g-1 ao fim dos 35 dias de armazenamento, de acordo com estes autores o extrato não apresentou nenhum efeito positivo sobre a estabilidade microbiana durante o armazenamento.

Comportamento semelhante foi observado em contagens totais de microrganismos psicrotróficos aeróbios (Tabela 7). Para estes microrganismos podese observar nos tratamentos com 2 e 4\% de EJM a redução de um ciclo log ao final do quarto dia de estocagem, destacando o potencial antimicrobiano do EJM. A partir do oitavo dia de estocagem todos os tratamentos ultrapassaram o limite recomendado pela International Commission on Microbiological Specifications for Foods (ICMSF, 1986), que é de $10^{7} \mathrm{UFC} \mathrm{g}^{-1}$, indicando deterioração. Considerando a contagem total microbiana em produtos cárneos, cargas microbianas superiores levam a perda sensorial devido, principalmente, às alterações do odor, cor e sabor. Com estes resultados, a vida útil das linguiças frescais armazenadas nas condições apresentadas seria de no máximo quatro dias, sendo a partir do oitavo dia considerados inaceitáveis microbiologicamente.

Para as bactérias láticas todos os tratamentos apresentaram $4 \log$ UFC g ${ }^{-1}$ no início do armazenamento e ao longo da estocagem pode-se verificar um aumento, atingindo valores próximos de $6 \log$ UFC $\mathrm{g}^{-1} \mathrm{em}$ todos os tratamentos, porém, nenhum tratamento ultrapassou o limite de $10^{7} \mathrm{UFC} \mathrm{g}^{-1}$, estabelecido pela International Commission on Microbiological Specifications for Foods (ICMSF, 1986). Nos tratamentos com EJM, a justificativa para o aumento de microrganismo pode ser devido ao baixo $\mathrm{pH}$ do extrato de jabuticaba $(3,7)$. Diferentemente dos microrganismos psicrotróficos, não se verificou uma tendência clara de proteção das linguiças contra a proliferação de bactérias lácticas em função da adição de EJM. 
Tabela 7. Características microbiológicas (Log UFC.g-1) das linguiças frescais durante armazenamento refrigerado.

\begin{tabular}{cccccc}
\hline Microrganismos & Dias & Controle & $\begin{array}{c}\text { Carmim de } \\
\text { cochonilha }\end{array}$ & $\begin{array}{c}\text { Jabuticaba } \\
\mathbf{2 \%}\end{array}$ & $\begin{array}{c}\text { Jabuticaba } \\
\mathbf{4} \%\end{array}$ \\
\hline Coliformes a $45^{\circ} \mathrm{C}$ & 1 & 1,4 & 1,4 & 1,3 & 1,4 \\
& 15 & 1,4 & 1,3 & 0,9 & 0,9 \\
Staphylococcus aureus & 1 & 1,0 & 1,0 & 0,5 & 0,5 \\
& 15 & 0,9 & 0,9 & 0,8 & 0,0 \\
Mesófilos aeróbios & 1 & 4,8 & 4,6 & 4,0 & 4,1 \\
& 15 & 4,6 & 4,5 & 4,0 & 4,3 \\
Psicrotróficos aeróbios & 1 & 5,9 & 6,0 & 5,8 & 6,1 \\
& 4 & 7,1 & 7,4 & 6,3 & 6,3 \\
& 11 & 7,6 & 7,8 & 7,8 & 7,7 \\
& 15 & 8,9 & 7,8 & 7,4 & 7,5 \\
& & & 8,1 & 7,3 & 7,3 \\
& 1 & 4,0 & 4,1 & 4,0 & 4,2 \\
Bactérias lácticas & 4 & 4,6 & 5,1 & 5,1 & 5,1 \\
& 11 & 5,1 & 5,6 & 5,9 & 5,3 \\
& 15 & 6,0 & 5,2 & 5,7 & 5,8 \\
& 4,0 & 5,8 & 5,9 & 6,0 \\
\hline
\end{tabular}

Controle: Linguiça frescal sem adição de corante; Carmim de cochonilha: linguiça frescal com corante tradicional carmim de cochonilha; Jabuticaba $2 \%$ : linguiça frescal com adição de $2 \%$ de EJM; Jabuticaba 4\%: linguiça frescal com adição de 4\% de EJM.

Os resultados encontrados para a Salmonella sp. foram negativos em todos os tratamentos, indicando ausência em $25 \mathrm{~g}$, estando de acordo com o preconizado pela legislação brasileira (BRASIL, 2001).

\subsubsection{Análise sensorial}

Os resultados do teste de aceitação sensorial estão apresentados na Tabela 8. A adição de 4\% de EJM diminuiu significativamente os valores para os atributos textura e qualidade global, representando uma diminuição na aceitação sensorial. Os tratamentos com 2 e 4\% de EJM diminuíram a aceitação do consumidor sobre 0 atributo cor, o que pode ser explicado provavelmente pela cor mais escura da linguiça causada pela adição de EJM. No entanto, não houve diferença significativa $(p>0,05)$ 
entre o controle, carmim de cochonilha e $2 \%$ de EJM para a maioria dos atributos sensoriais analisados.

Almeida et al. (2015) avaliaram a aceitação sensorial de mortadela tipo bologna adicionada com extrato etanólico da casca de jabuticaba liofilizada, logo após o processamento e durante o período de armazenamento. Eles não encontraram nenhuma diferença significativa $(p>0,05)$ nos atributos sensoriais analisados entre os tratamentos controle e com adição de 0,25 e 0,50\% extrato etanólico da casca de jabuticaba liofilizada. No entanto, a adição de 0,75 e 1\% de extrato reduziu significativamente o atributo qualidade global, indicando que estas concentrações diminuíram a aceitação sensorial de mortadela tipo bologna.

Tabela 8. Aceitação sensorial das linguiças frescais.

\begin{tabular}{ccccc}
\hline CARACTERÍSTICAS & Controle & $\begin{array}{c}\text { Carmim de } \\
\text { Cochonilha }\end{array}$ & $\begin{array}{c}\text { Jabuticaba } \\
\mathbf{2 \%}\end{array}$ & $\begin{array}{c}\text { Jabuticaba } \\
\mathbf{4} \%\end{array}$ \\
\hline Cor & $5,25 \pm 0,17^{\mathrm{a}}$ & $5,68 \pm 0,18^{\mathrm{a}}$ & $4,39 \pm 0,21^{\mathrm{b}}$ & $3,95 \pm 0,20^{\mathrm{b}}$ \\
Aroma & $6,22 \pm 0,13^{\mathrm{a}}$ & $6,44 \pm 0,14^{\mathrm{a}}$ & $6,30 \pm 0,14^{\mathrm{a}}$ & $6,14 \pm 0,17^{\mathrm{a}}$ \\
Textura & $6,50 \pm 0,15^{\mathrm{a}}$ & $6,56 \pm 0,16^{\mathrm{a}}$ & $6,47 \pm 0,15^{\mathrm{a}}$ & $5,88 \pm 0,17^{\mathrm{b}}$ \\
Sabor & $6,63 \pm 0,16^{\mathrm{ab}}$ & $7,00 \pm 0,15^{\mathrm{a}}$ & $6,91 \pm 0,15^{\mathrm{a}}$ & $6,31 \pm 0,19^{\mathrm{b}}$ \\
Qualidade global & $6,25 \pm 0,15^{\mathrm{a}}$ & $6,56 \pm 0,13^{\mathrm{a}}$ & $6,22 \pm 0,14^{\mathrm{a}}$ & $5,65 \pm 0,17^{\mathrm{b}}$ \\
\hline
\end{tabular}

Controle: linguiça frescal sem adição de corante, Carmim de cochonilha: linguiça frescal com corante tradicional carmim de cochonilha, Jabuticaba $2 \%$ : linguiça frescal com adição de $2 \%$ de EJM, Jabuticaba 4\%: linguiça frescal com adição de 4\% de EJM.

Resultados expressos pela média \pm erro padrão. Letras minúsculas diferentes numa mesma linha indicam diferenças significativas $(p<0,05)$ entre os tratamentos.

\subsection{Aplicação do extrato de jabuticaba microencapsulado em mortadela}

\subsubsection{Composição centesimal da mortadela}

Os resultados médios obtidos para a composição centesimal da mortadela nas três repetições realizadas estão apresentados na Tabela 9. Não houve diferença ( $p>0,05)$ entre os tratamentos. Com exceção do teor de proteínas, que ficou ligeiramente abaixo do limite, os resultados estão de acordo com o previsto na legislação brasileira, que estabelece máximo de 65\% para umidade, mínimo de 12\% para proteína e máximo de 30\% para lipídeos (BRASIL, 2000). Se esse produto fosse lançado no mercado seria necessário alterar a formulação para aumentar em aproximadamente $0,5 \%$ o teor de proteínas, o que poderia ser realizado com um 
aumento do teor de carne ou mesmo adição de alguma fonte de proteína não cárnea, como o isolado protéico de soja.

Tabela 9. Composição centesimal (\%) das amostras de mortadela.

\begin{tabular}{ccccc}
\hline Mortadela & Umidade & Proteína & Lipídeos & Cinzas \\
\hline Controle & $65,75 \pm 2,08^{\mathrm{a}}$ & $11,79 \pm 0,34^{\mathrm{a}}$ & $12,82 \pm 1,41^{\mathrm{a}}$ & $3,03 \pm 0,05^{\mathrm{a}}$ \\
Carmim de cochonilha & $65,97 \pm 1,35^{\mathrm{a}}$ & $11,55 \pm 0,04^{\mathrm{a}}$ & $12,82 \pm 1,52^{\mathrm{a}}$ & $3,09 \pm 0,06^{\mathrm{a}}$ \\
Jabuticaba & $64,50 \pm 1,39^{\mathrm{a}}$ & $11,51 \pm 0,34^{\mathrm{a}}$ & $12,74 \pm 1,21^{\mathrm{a}}$ & $3,15 \pm 0,14^{\mathrm{a}}$ \\
\hline
\end{tabular}

Controle: mortadela sem adição de corante, Carmim de cochonilha: mortadela com corante tradicional carmim de cochonilha e Jabuticaba: mortadela com adição de $2 \%$ de EJM.

Resultados expressos pela média \pm erro padrão. Letras minúsculas diferentes numa mesma coluna indicam diferenças significativas $(p<0,05)$ entre os tratamentos.

\subsubsection{Estabilidade físico-química}

Não houve diferença $(p<0,05)$ entre os tratamentos e nem ao longo do tempo para o índice de TBARS $(p<0,05)$, sendo que os valores encontrados foram $0,14 \pm 0,14$ $\mathrm{mg}$ de malonaldeído/kg de amostra para o tratamento com EJM e nos tratamentos controle (sem adição de corante) e carmim de cochonilha os valores encontrados foram $0,21 \pm 0,14$ e 0,29 $\pm 0,14 \mathrm{mg}$ de malonaldeído/kg de amostra, respectivamente. Vale ressaltar que os valores de TBARS para todos os tratamentos foram aceitáveis durante todo o período de estocagem, sendo que provavelmente as boas condições de processamento e armazenamento, além do poder antioxidante de outros ingredientes como o nitrito e os condimentos, podem ter evitado uma maior oxidação e a possível evidência de um maior poder antioxidante apresentado pelo EJM.

Almeida et al. (2015) adicionaram extrato etanólico de casca de jabuticaba liofilizado nas concentrações zero (controle), 0,25, 0,5, 0,75 e 1,0\% em mortadela tipo bologna, armazenadas sob refrigeração por 35 dias e encontraram valores de TBARS de aproximadamente $0,3 \mathrm{mg}$ de MDA/kg de amostra nos tratamentos com 0,5, 0,75 e $1,0 \%$ de extrato de jabuticaba, e nas amostras controle e $0,25 \%$ eles verificaram 0,5 $\mathrm{mg}$ de $\mathrm{MDA} / \mathrm{kg}$ de amostra. Esses valores foram superiores aos encontrados no presente estudo, ressalta-se ainda que as condições de obtenção do extrato de jabuticaba foram diferentes, Almeida et al. (2015) realizaram a extração com etanol e desidratação do extrato por liofilização, enquanto no presente estudo foi realizada extração aquosa e secagem por spray dryer.

Ozvural e Vural (2012) avaliaram a adição de extrato de semente de uva (nas concentrações $0,01,0,03,0,05,01,0,3$ e 0,5\%) em salsichas frankfurters e 
observaram que o aumento da concentração do extrato reduziu os valores de TBARS nas salsichas, provavelmente, devido ao alto conteúdo de compostos fenólicos presente no extrato. Viuda-Martos et al. (2010) avaliaram os efeitos da adição de $0,02 \%$ de óleo de tomilho e $0,02 \%$ de alecrim em mortadelas tipo bologna estocadas por 24 dias, os autores observaram índices inferiores para mortadelas com os óleos essenciais e também foi observado efeito significativo de tempo de estocagem.

No trabalho de Doménech-Asensi et al. (2013), mortadela adicionada com pasta de tomate apresentou melhora na estabilidade do produto durante o período de vida útil, reduzindo significativamente a oxidação lipídica associada com o armazenamento. Berasategi et al. (2014) avaliaram a adição de Melissa officinalis em mortadelas tipo bologna reduzidas de gordura, e os resultados demonstraram a eficiência do extrato em prevenir a oxidação lipídica da mortadela.

No trabalho de Pereira et al. (2010), foram avaliadas a estabilidade de mortadelas adicionadas de extrato da casca de manga (nas concentrações 0,1 e $0,2 \%$ ) como antioxidante natural e $0,01 \%$ de antioxidante sintético (butil-hidroxitolueno - BHT) armazenadas a $2^{\circ} \mathrm{C}$ por 21 dias, e os resultados encontrados foram que a adição de $0,1 \%$ de extrato da casca de manga não afetou o valor de TBARS das mortadelas armazenadas por 21 dias, enquanto o tratamento com $0,2 \%$ de extrato natural apresentou redução destes valores $(0,29$ a $0,25 \mathrm{mg}$ de malonaldeído/kg de amostra) aos 21 dias de estocagem, resultados similares ao antioxidante sintético $(0,22$ a $0,30 \mathrm{mg}$ de malonaldeído/kg de amostra). De acordo com os autores, o mecanismo do efeito protetor do extrato natural na oxidação lipídica pode ser decorrente da presença de polifenóis, antocianinas e carotenoides e o potencial antioxidante demonstrado pode ser resultante das ações sinergísticas desses compostos bioativos.

Para os valores de $\mathrm{pH}$ houve diferença $(\mathrm{p}<0,05)$ entre os tratamentos carmim de cochonilha $(6,27 \pm 0,29)$ e extrato de jabuticaba $(6,14 \pm 0,28)$, mas não houve diferença $(p>0,05)$ ao longo do tempo, sendo que a mortadela com EJM apresentou um valor mais baixo de $\mathrm{pH}$, o que pode ser devido ao baixo $\mathrm{pH}$ apresentado pelo extrato de jabuticaba $(3,7)$, porém o menor valor não interferiu na qualidade do produto estocado por 56 dias.

Contrariamente, no trabalho de Almeida et al. (2015) os autores encontraram valores de $\mathrm{pH}$ em mortadela tipo bologna com extrato etanólico de casca de jabuticaba liofilizado variando de 6,1 a 5,9 em todos os tratamentos nos 35 dias de 
armazenamento, os autores concluíram que a diminuição do $\mathrm{pH}$ ocorreu pela alta acidez do extrato, mas os valores foram considerados normais para este embutido. Pereira et al. (2010) verificaram que o tipo de antioxidante (natural e sintético) em mortadelas também diminuiu o valor de $\mathrm{pH}$ a partir do sétimo dia de estocagem a $2^{\circ} \mathrm{C}$, o tratamento com $0,01 \%$ de $\mathrm{BHT}$ variou de 6,17 a 6,$13 ; 0,1 \%$ de extrato da casca de manga variou de 6,15 a 6,08 e 0,2\% de extrato da casca de manga variou de 6,15 a 6,03 , no entanto os autores concluíram que os valores encontrados estão dentro dos níveis aceitáveis para boa conservação de alimentos processados.

Para os resultados da cor objetiva, em relação ao parâmetro $L^{*}$, não houve diferença $(p>0,05)$ entre os tratamentos, ocorrendo aumento $(p<0,05)$ ao longo do tempo para todos os tratamentos, que pode ser explicado por um modelo linear, conforme apresentado na figura 19.

Figura 19. Valores de $L^{*}$ ao longo da estocagem refrigerada da mortadela.

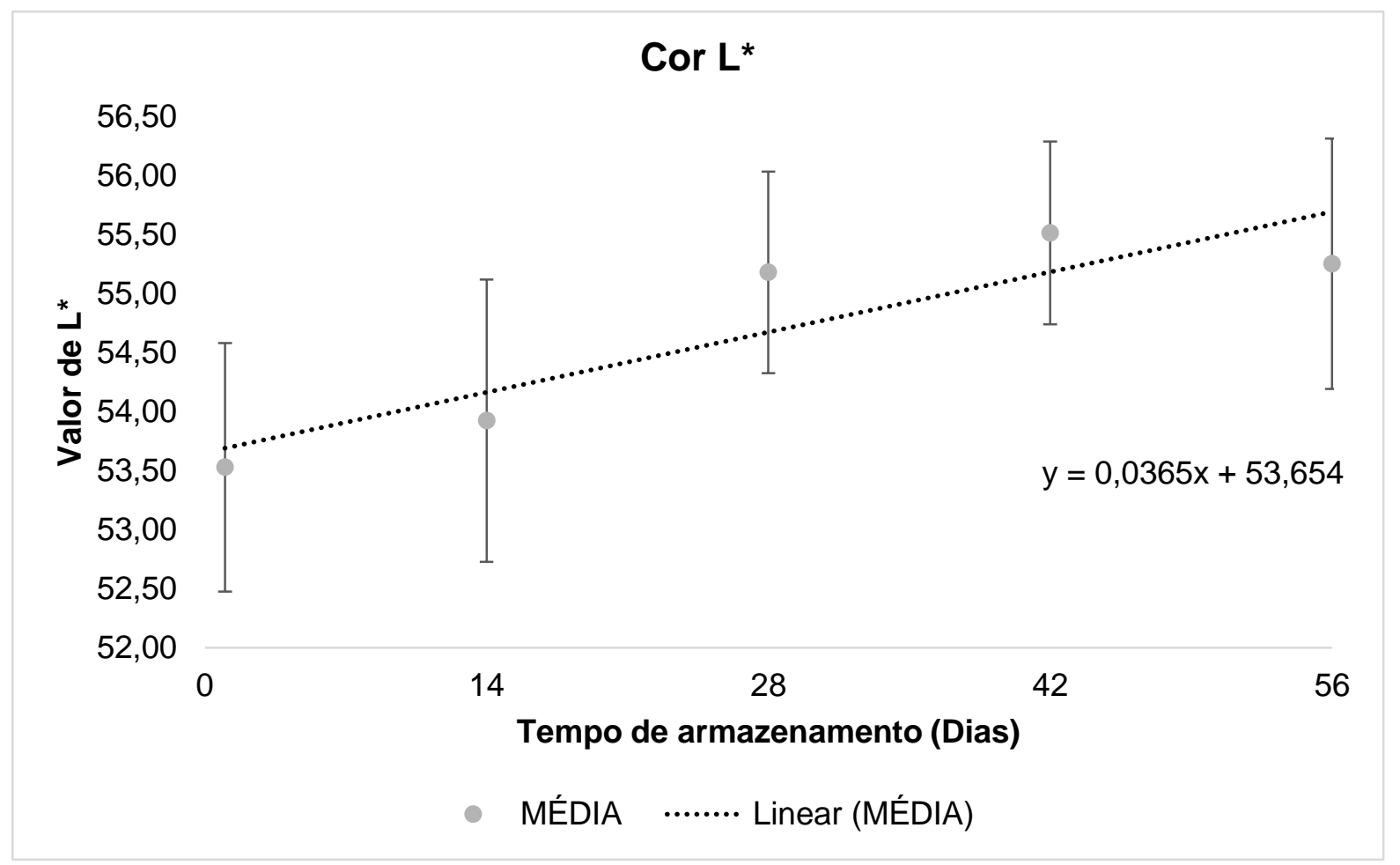

Para o parâmetro $a^{*}$ (Figura 20$)$, houve diferença $(p<0,05)$ entre os tratamentos e ao longo do tempo $(p<0,05)$. Pode-se observar que a coloração vermelha foi maior no tratamento com carmim de cochonilha, seguida do tratamento sem corante e por último do tratamento com $2 \%$ de extrato de jabuticaba. Estes resultados foram também evidenciados na análise sensorial, na qual os consumidores deram notas 
maiores para o tratamento com o corante comercial, com a coloração mais arroxeada do extrato de jabuticaba interferindo no produto final e os consumidores preferindo os produtos com uma coloração mais rosada.

Figura 20. Valores de $\mathrm{a}^{*}$ ao longo da estocagem refrigerada da mortadela.

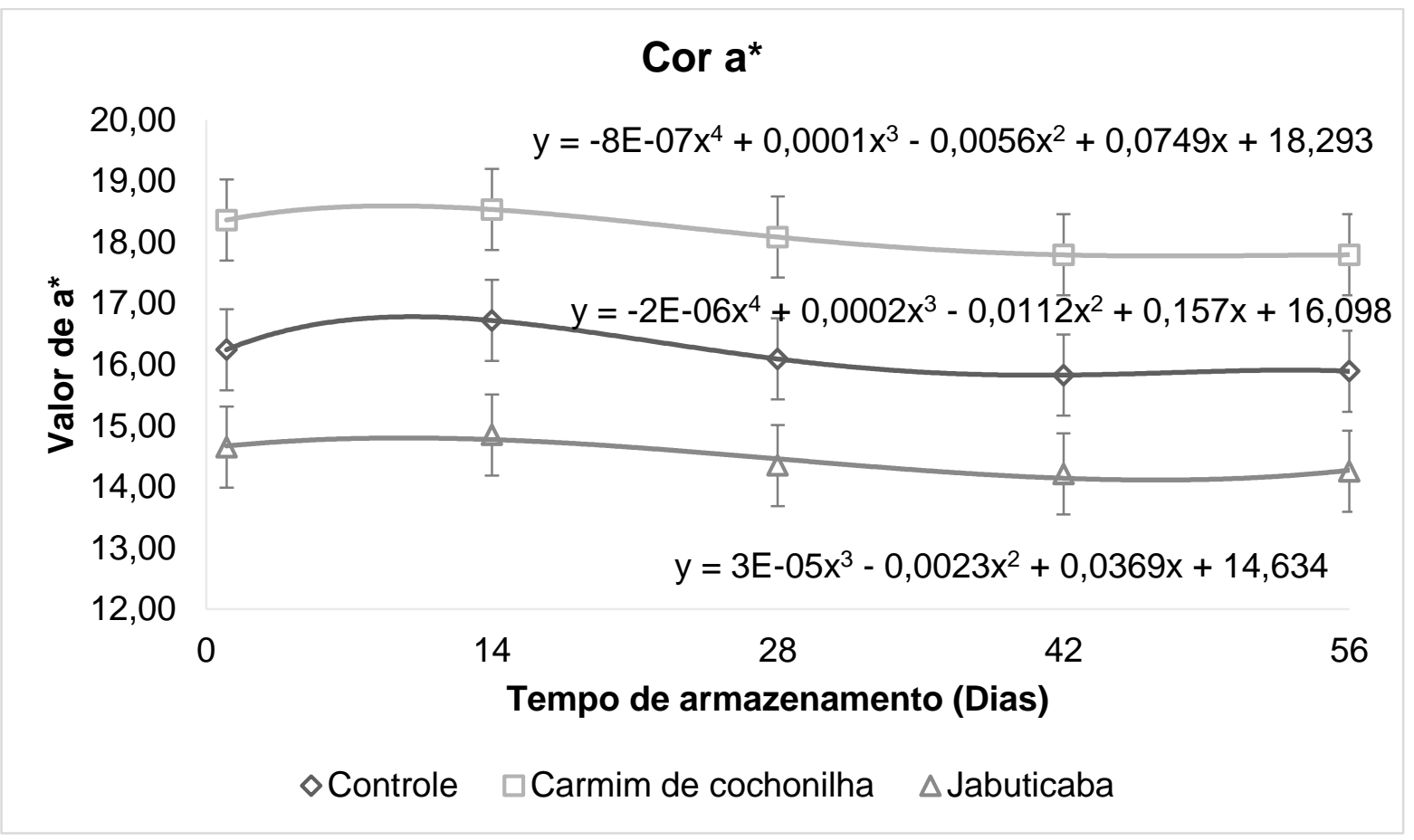

Para o parâmetro $b^{*}$ houve variação significativa $(p<0,05)$ ao longo do tempo, no entanto este comportamento só pode ser bem explicado por um polinômio de $4^{\circ} \mathrm{grau}$, não sendo possível, portanto, verificar uma tendência clara da variação deste parâmetro nas diferentes amostras ao longo do tempo. Em relação aos tratamentos, verificou-se diferença $(p<0,05)$ entre $o$ tratamento sem corante $(14,41 \pm 0,51)$ e o tratamento com extrato de jabuticaba $(11,57 \pm 0,51)$. Para o tratamento com carmim de cochonilha o valor encontrado foi de $13,61 \pm 0,51$ e não diferiu $(p>0,05)$ dos demais tratamentos.

De uma maneira geral, os resultados encontrados demonstraram uma coloração mais escura para o tratamento com extrato de jabuticaba, sendo que a mortadela com carmim de cochonilha ficou mais rosada conforme demonstrado na figura 21. 
Figura 21. Tratamentos de mortadela.
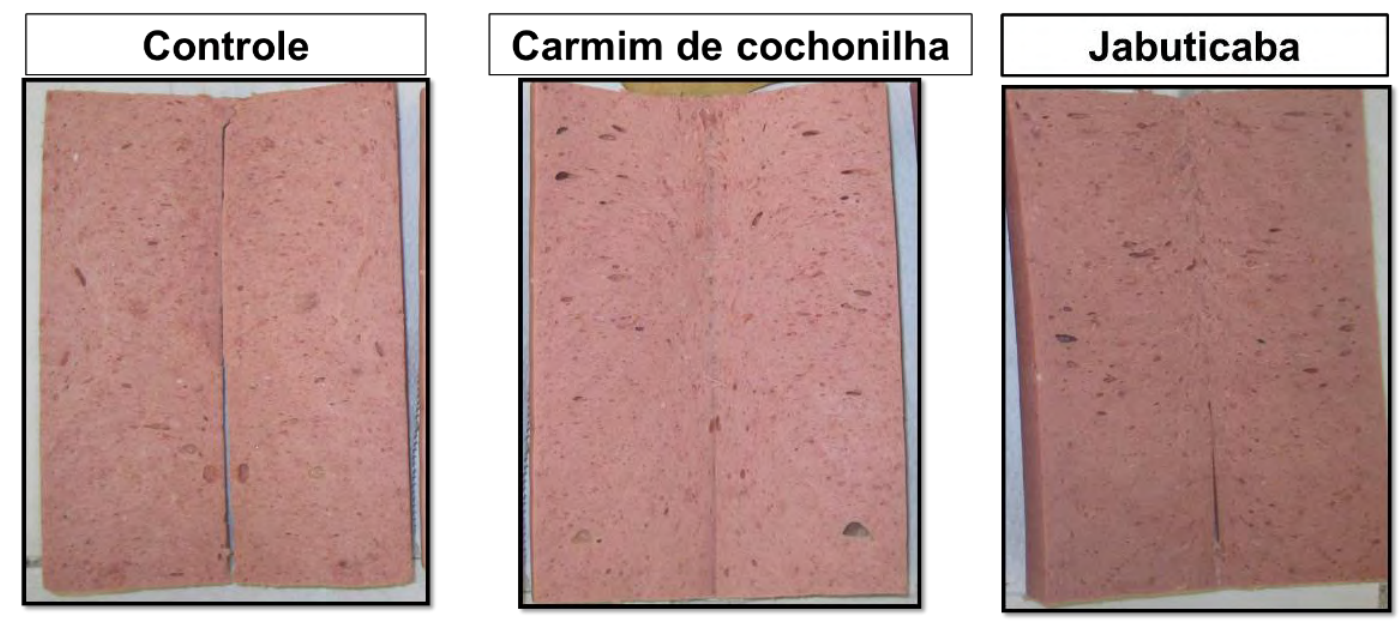

Controle: mortadela sem adição de corante; Carmim de cochonilha: mortadela com corante tradicional carmim de cochonilha; Jabuticaba: mortadela com adição de $2 \%$ de EJM.

No trabalho realizado por Almeida et al. (2015), os autores verificaram que as concentrações 0,25 e 0,5\% de extrato etanólico de casca de jabuticaba liofilizado em mortadela tipo bologna não afetaram os valores de $L^{*}$ e b*, já a adição de 0,75 e 1\% diminuíram valores de $a^{*}$ de maneira similar ao presente trabalho, porém, apesar das diferenças observadas na cor instrumental, na avaliação visual não foi detectada diferença entre os tratamentos em relação ao controle (sem extrato de jabuticaba).

Viuda-Martos et al. (2010) avaliaram os efeitos da adição de óleo de tomilho e alecrim (na concentração de 0,02\% para ambos) em mortadelas tipo bologna estocadas por 24 dias e verificaram um aumento nos valores de $L^{*}$ e b* e redução no valor de $\mathrm{a}^{*}$, em consequência da adição dos óleos essenciais.

Já Pereira et al. (2010), ao utilizarem extrato da casca de manga em mortadelas encontraram maiores valores de $a^{*}$ nos tratamentos com o extrato natural quando comparados ao BHT. Desta forma, a inclusão do extrato contribuiu para a coloração vermelha do produto. $\mathrm{O}$ tratamento com $B H T$ apresentou maiores valores de $L^{*} e b^{*}$, e o tratamento com $0,1 \%$ também apresentou maior valor de $b^{*}$. Esse acréscimo sugere que essa concentração não foi suficiente para evitar a descoloração do produto durante a estocagem e os resultados indicaram que $0,2 \%$ de extrato da casca de manga apresentou melhor efeito antioxidante sobre a cor, retardando a descoloração das mortadelas. 


\subsubsection{Estabilidade microbiológica}

Nenhum tratamento apresentou contagens de coliformes a $45^{\circ} \mathrm{C}$, Staphylococcus aureus e clostrídios sulfito redutores nem a presença de Salmonella sp., o que demonstra que o processo de cozimento e, consequentemente, a pasteurização dos produtos foi efetiva. Resultados semelhantes foram observados por Almeida et al. (2015), que, ao analisarem mortadela tipo bologna com extrato etanólico de casca de jabuticaba liofilizado, não detectaram a presença de coliformes termotolerantes nos 35 dias de armazenamento, o que pode ser devido ao produto ser um embutido cozido e atingir a temperatura de pasteurização.

As contagens totais de microrganismos anaeróbios mesófilos e psicrotróficos e bactérias láticas estão apresentadas na Tabela 10. Para os três grupos de microrganismos não se verificaram diferenças claras entre os tratamentos e as

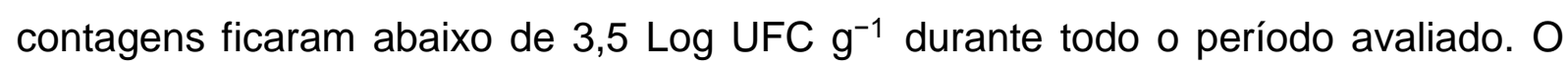
tratamento térmico aplicado, as boas práticas na fabricação e adequadas condições de armazemanento podem ter impedido uma proliferação destes microrganismos, de forma a evidenciar uma possível atividade antimicrobiana em função da aplicação do extrato de jabuticaba.

Diferentemente, no trabalho de Almeida et al. (2015), foram relatadas contagens de microrganismos mesófilos próximas a 4 log UFC $\mathrm{g}^{-1}$ em mortadela tipo bologna adicionada com extrato etanólico da casca de jabuticaba liofilizada no início do armazenamento e 5,5 UFC g-1 $\log$ ao fim dos 35 dias de armazenamento. Estes autores concluíram que o extrato não apresentou nenhum efeito positivo sobre a estabilidade microbiana durante o armazenamento.

Os resultados para os microrganismos psicrotróficos e bactérias lácticas apresentaram valores variando de 1 a 3,4 log UFC $g^{-1}$, consequentemente, a pasteurização destes embutidos, as boas práticas na fabricação e a estocagem refrigerada podem ter sido os principais responsáveis por essas baixas contagens. 
Tabela 10. Características microbiológicas (Log UFC $\mathrm{g}^{-1}$ ) das mortadelas durante armazenamento refrigerado.

\begin{tabular}{ccccc}
\hline Microrganismos & Dias & Controle & Carmim de cochonilha & Jabuticaba \\
\hline & 1 & 1,0 & 1,5 & 1,7 \\
Mesófilos anaeróbios & 14 & 1,6 & 1,6 & $<1,0$ \\
& 28 & 1,5 & 2,1 & 1,9 \\
& 42 & 2,2 & $<1,0$ & 2,1 \\
& 56 & 1,0 & 2,3 & 1,4 \\
Psicrotróficos & 1 & $<1,0$ & 1,2 & 1,6 \\
anaeróbios & 14 & 1,8 & 2,3 & 2,1 \\
& 28 & 1,6 & 3,4 & 2,0 \\
& 42 & 1,5 & 2,4 & 1,2 \\
& 56 & $<1,0$ & 1,7 & 1,5 \\
Bactérias lácticas & & & & \\
& 1 & $<1,0$ & 1,4 & 1,7 \\
& 14 & 1,7 & 1,7 & 1,5 \\
& 28 & $<1,0$ & 1,5 & 1,9 \\
& 42 & $<1,0$ & 1,0 & 1,5 \\
& 56 & $<1,0$ & 2,6 & $<1,0$ \\
\hline
\end{tabular}

Controle: mortadela sem adição de corante, Carmim de cochonilha: mortadela com corante tradicional carmim de cochonilha, Jabuticaba: mortadela com adição de 2\% de EJM.

De acordo com os resultados encontrados não pode ser comprovada a eficiência do extrato natural como antimicrobiano devido ao cozimento do produto, porém, a substituição do corante comercial pelo extrato de jabuticaba microencapsulado apresenta grandes vantagens quanto à utilização de resíduos de indústrias de beneficiamento de frutas e a adição de um composto bioativo em embutidos que serão consumidos pela população interessada em produtos mais saudáveis.

\subsubsection{Estabilidade sensorial}

Não houve alteração $(p>0,05)$ da aceitação sensorial do atributo cor ao longo de todo período de armazenamento refrigerado das mortadelas. No entanto, verificaram-se diferenças $(p<0,05)$ entre todos os tratamentos, sendo que a amostra com carmim de cochonilha foi a mais aceita em relação à cor $(7,35)$, seguida pela amostra sem corante $(6,91)$ e a amostra com $2 \%$ de extrato de jabuticaba foi a menos 
aceita pelos provadores $(5,45)$. Isto se deve provavelmente à coloração mais arroxeada desta amostra (ver Figura 21), pois os consumidores estão habituados a escolher produtos com coloração mais rosada para compra de embutidos cárneos.

Em relação à aceitação do atributo aroma, todos os tratamentos diferiram entre si $(p<0,05)$ e ao longo do tempo $(p<0,05)$, mas não houve interação tempo $x$ tratamento $(p>0,05)$. Ou seja, os tratamentos diferiram mas apresentaram um comportamento polinomial similar de queda seguida de aumento das notas atribuídas durante o período de armazenamento (Figura 22), sendo que o tratamento com EJM recebeu as menores notas, significando menor aceitação quanto ao aroma deste produto.

Figura 22. Avaliação sensorial do atributo aroma da mortadela ao longo da estocagem refrigerada $(n=60)$.

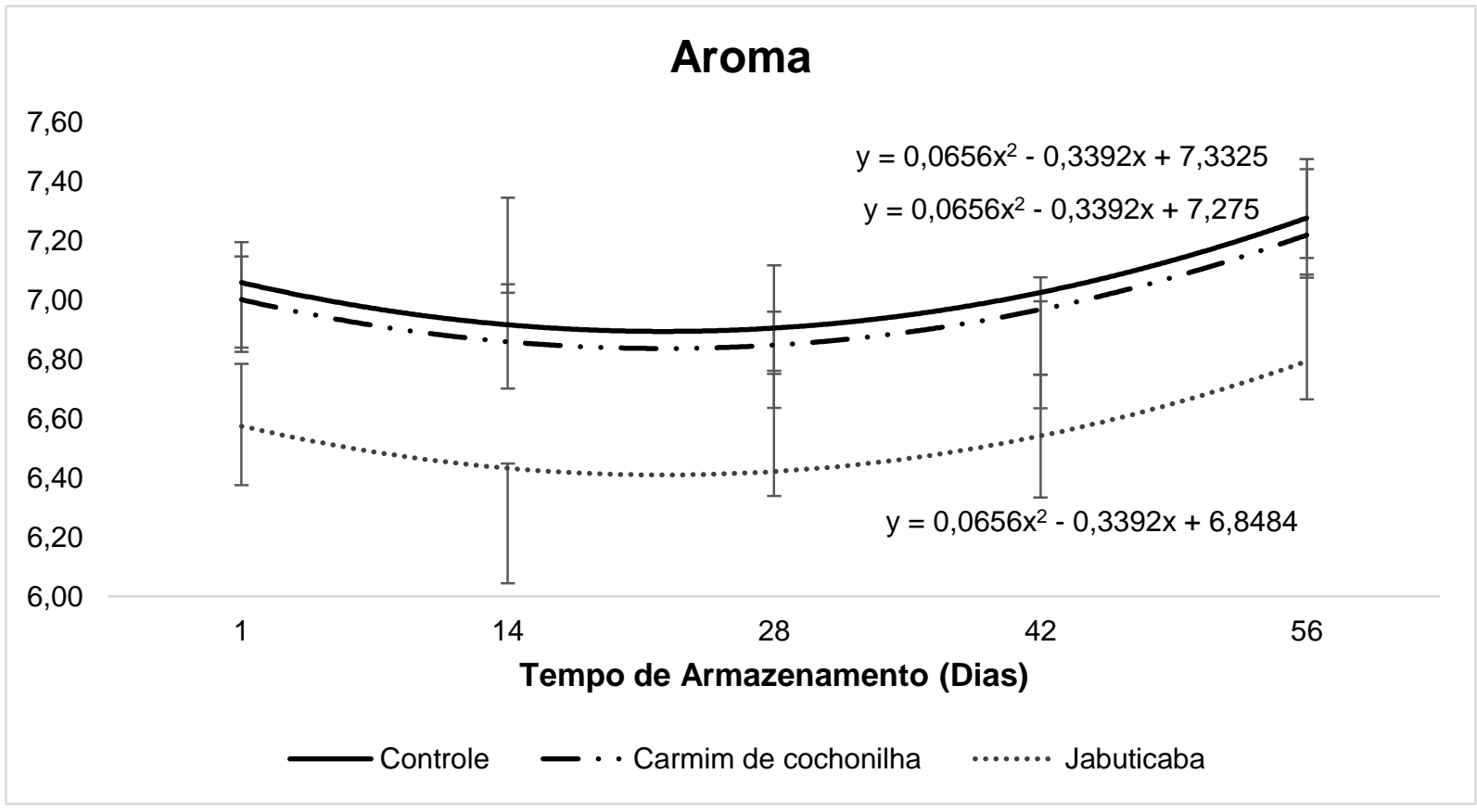

$\mathrm{Na}$ avaliação da aceitação pelos consumidores do atributo textura (Figura 23), novamente todos os tratamentos diferiram entre si $(p<0,05)$ e ao longo do tempo $(p<0,05)$, mas não tiveram interação tempo x tratamento $(p>0,05)$. Assim sendo, todos os tratamentos apresentaram comportamento similar ao longo do armazenamento, mas que só pode ser explicado por um polinômio de $4^{\circ}$ grau, não sendo possível se verificar uma tendência clara de aumento ou redução da aceitação ao longo do tempo para este atributo. Ao se comparar as diferentes mortadelas, verifica-se que o 
tratamento com 2\% de EJM apresentou as maiores notas, sendo mais aceita pelos consumidores no atributo textura deste embutido.

Figura 23. Avaliação sensorial do atributo textura da mortadela ao longo da estocagem refrigerada $(n=60)$.

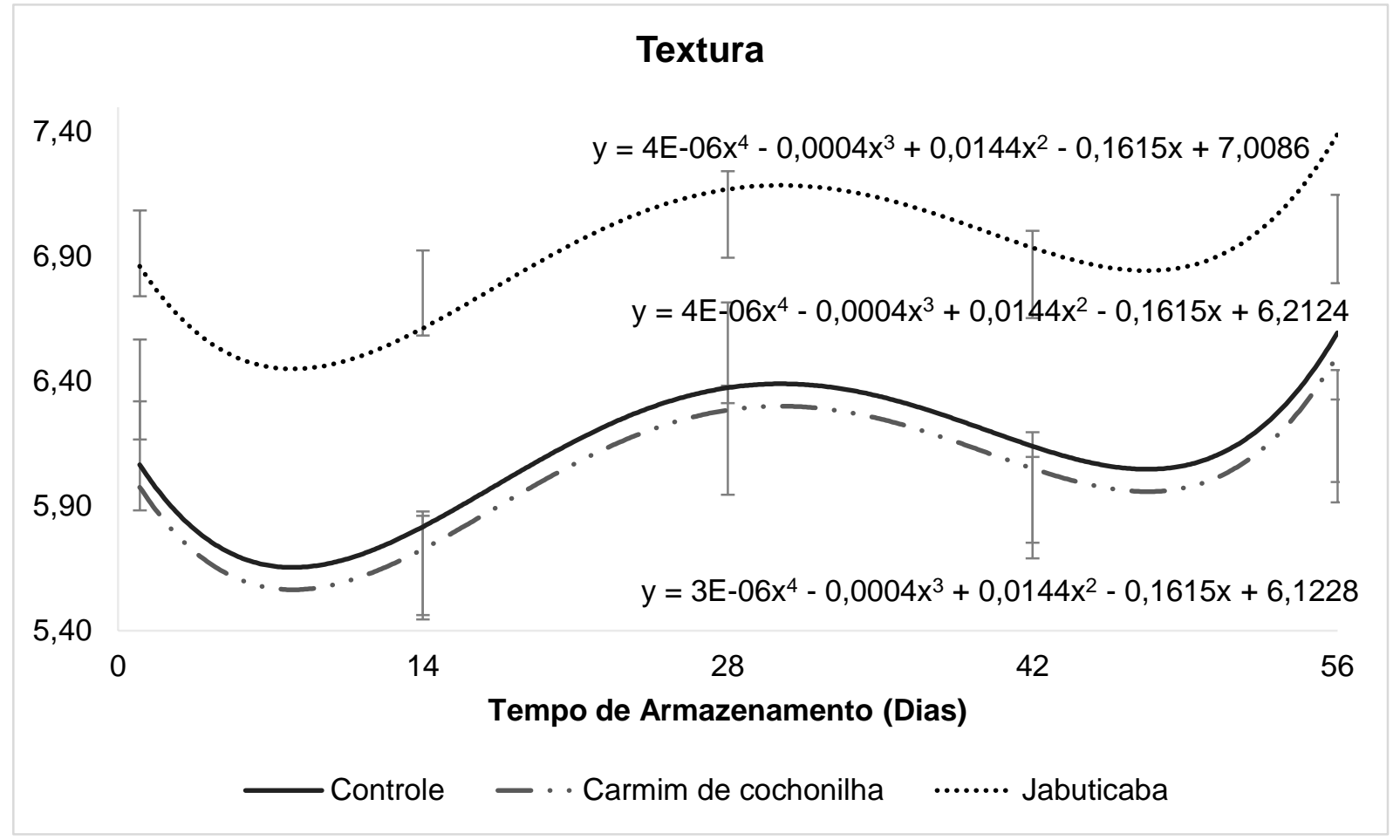

No atributo sabor houve novamente diferença significativa $(p<0,05)$ entre os tratamentos e ao longo do tempo $(p<0,05)$, mas não se verificou interação tempo $x$ tratamento $(p>0,05)$, conforme apresentado na Figura 24. Desta forma, todos os tratamentos apresentaram comportamento similar ao longo do armazenamento, explicado por um polinômio de $4^{\circ}$ grau, no qual não se pode constatar uma tendência de aumento ou redução da aceitação para este atributo ao longo do tempo. Ao se comparar os diferentes tratamentos, verifica-se que o tratamento com $2 \%$ de EJM apresentou as melhores notas, indicando uma melhor aceitação pelos provadores quanto ao sabor, justificando seu uso em embutidos cárneos. 
Figura 24. Avaliação sensorial do atributo sabor da mortadela ao longo da estocagem refrigerada $(n=60)$.

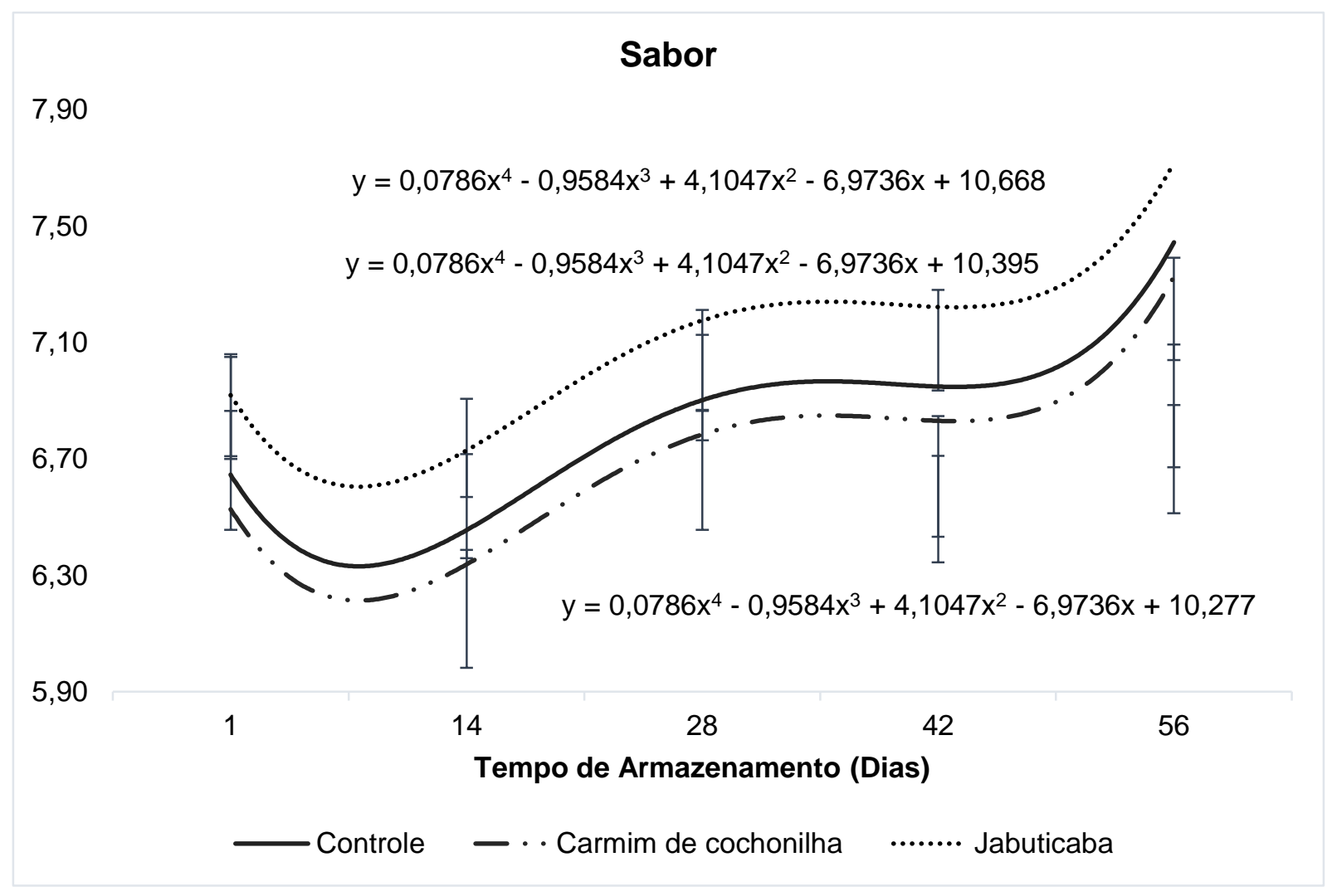

Para os atributos de qualidade global, não houve diferença $(p>0,05)$ entre os tratamentos, indicando que a adição de 2\% de EJM, apesar de ter reduzido a aceitação sensorial da cor da mortadela, não influenciou negativamente a aceitação da mortadela como um todo, sendo possível recomendar a substituição do corante carmim de cochonilha por $2 \%$ de extrato de jabuticaba microencapsulado em mortadela, visando a ingestão de um produto saudável. Desta maneira, todos os tratamentos apresentaram comportamento similar ao longo do armazenamento, porém somente explanado por um polinômio de $4^{\circ} \mathrm{grau}$, novamente não se verifica um possível aumento ou redução da aceitação para o atributo qualidade global em todo o período de estocagem (Figura 25). 
Figura 25. Avaliação sensorial do atributo qualidade global da mortadela ao longo da estocagem refrigerada $(n=60)$.

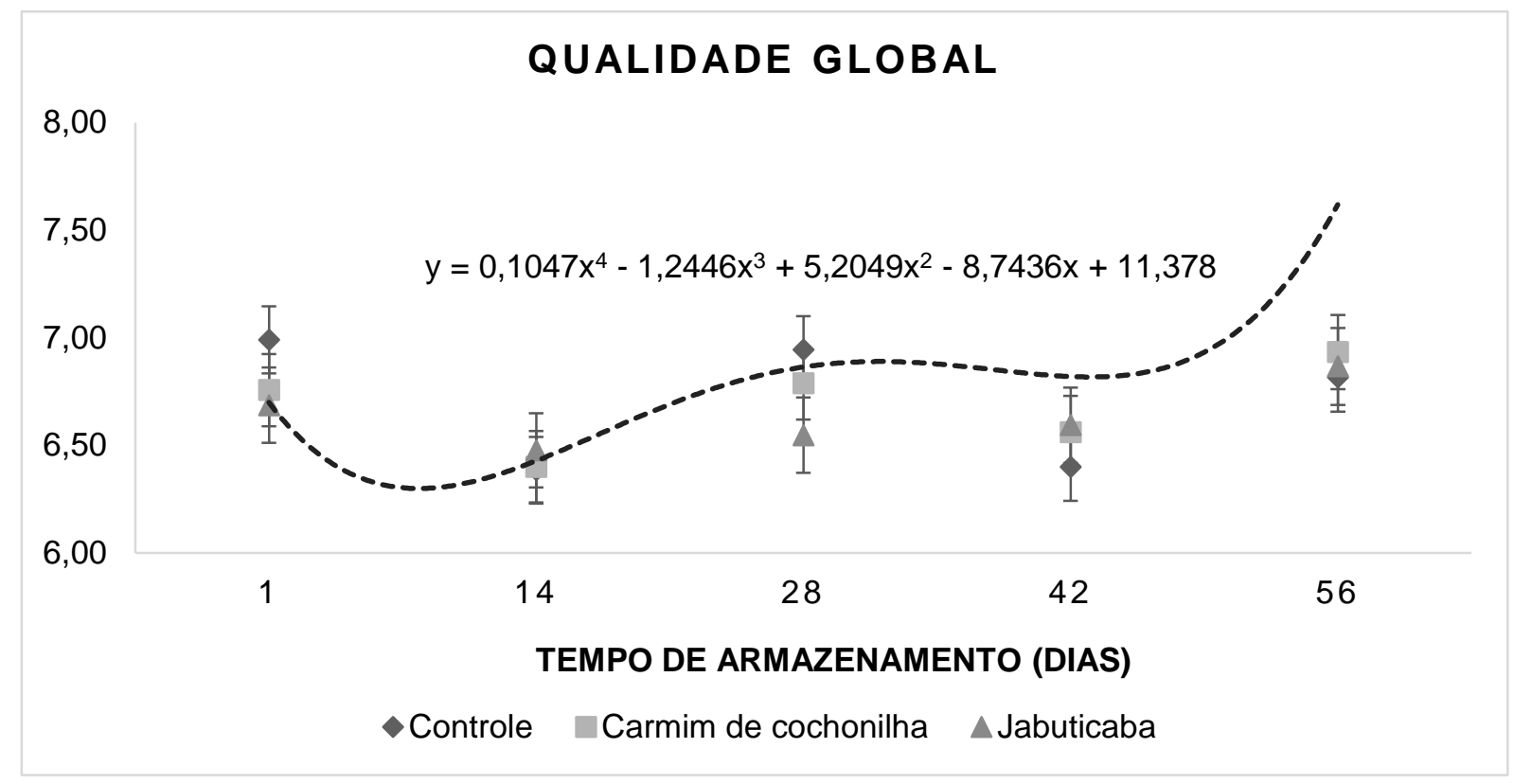

No trabalho de Ozvural e Vural (2012), salsichas frankfurters adicionadas de $0,01,0,03,0,05$ e $0,1 \%$ do extrato de semente de uva foram tão bem aceitas quanto o tratamento controle (sem o extrato natural).

No trabalho de Doménech-Asensi et al. (2013), os resultados encontrados para avaliação sensorial de mortadela adicionada com pasta de tomate apresentaram notas mais altas sobre a intensidade da cor, mas não foram encontradas diferenças nos atributos de sabor e textura.

$\mathrm{Na}$ pesquisa realizada por Almeida et al. (2015), foi avaliada a aceitação sensorial de mortadela tipo bologna adicionada com extrato etanólico da casca de jabuticaba liofilizada, logo após o processamento e durante o período de armazenamento. Eles não encontraram nenhuma diferença significativa nos atributos sensoriais analisados entre os tratamentos controle e com adição de 0,25 e 0,5\% extrato etanólico da casca de jabuticaba liofilizada. No entanto, a adição de 0,75 e 1\% de extrato reduziu significativamente o atributo qualidade global, indicando que estas concentrações diminuíram a aceitação sensorial de mortadela tipo bologna. 


\section{Conclusão}

O extrato da casca da jabuticaba apresentou alto teor de antocianinas, com prevalência da cianidina-3-glicosídeo de $85,9 \%$ e apresentou também atividade antioxidante e efeito inibitório in vitro sobre o crescimento das bactérias testadas comprovando seu potencial antioxidante e antimicrobiano. A utilização desse extrato pelas indústrias pode agregar valor ao resíduo do processamento da jabuticaba, satisfazendo a busca por produtos naturais e contribuindo para a preservação do meio ambiente em função da redução dos resíduos descartados.

Os resultados relativos à aplicação em linguiça frescal suína confirmaram que o uso de $2 \%$ e $4 \%$ de EJM contribuiu para reduzir a oxidação lipídica durante 15 dias de armazenamento. No caso das análises microbiológicas, o EJM contribuiu para reduzir a contagem de microrganismos por apenas quatro dias. Sensorialmente, a adição de $4 \%$ de EJM afetou a textura e a qualidade global da linguiça, o que não aconteceu com $2 \%$ de EJM, que não comprometeu os atributos sensoriais avaliados, com exceção da cor. Assim sendo, recomenda-se a adição de 2\% de EJM substituindo o carmim de cochonilha na linguiça frescal, por se tratar de satisfazer as demandas por novas fontes de baixo custo e uso de pigmentos naturais, sendo benéfico para a saúde dos consumidores e do ambiente.

A adição de $2 \%$ de extrato aquoso de jabuticaba microencapsulado em mortadela não apresentou vantagem em relação à atividade antioxidante e antimicrobiana. No entanto, esta adição também não implicou em redução da aceitação sensorial global deste produto. Desta forma, é possível se recomendar a substituição do corante comercial carmim de cochonilha pelo extrato de jabuticaba microencapsulado na concentração de $2 \%$, trazendo a concepção de uso de um pigmento natural proveniente de fonte de baixo custo, com melhor aproveitamento do resíduo do processamento da jabuticaba e ainda com apelo de benefícios à saúde em função da utilização de produtos mais saudáveis em embutidos, por se tratar de um corante proveniente de uma fruta e não de um inseto. 


\section{Referências Bibliográficas}

ASSOCIATION OF OFFICIAL ANALYTICAL CHEMISTS - AOAC. AOAC-992.15 Crude protein in meat and meat products including pet foods - combustion method. Rockville: AOAC, 1992.

ABE, L. T.; LAJOLO, F. M. E; GENOVESE, M. I. Potential dietary sources of ellagic acid and other antioxidants among fruits consumed in Brazil: jabuticaba (Myrciaria jaboticaba (Vell.) Berg). Journal of the Science of Food Agriculture, Chichester, v. 92, p. 1679-1687, 2012.

ALENCAR, N. Cursos rápidos de tecnologia de produtos cárneos: embutidos finos - série A. Belo Horizonte: SEBRAE-MG, Fundação Centro Tecnológico de Minas Gerais/CETEC, 1994.

ALEZANDRO, M. R. et al. Comparative study of chemical and phenolic compositions of two species of jaboticaba: Myrciaria jaboticaba (Vell.) Berg and Myrciaria cauliflora (Mart.) O. Berg. Food Research International, Kidlington, v. 54, p. 468-477, 2013.

ALIBERTI, N. C. M. Influência da homogeneização a alta pressão sobre a retenção de antocianinas presentes na polpa de açaí (Euterpe oleraceae Mart.). 2009. 102 f. Tese (Doutorado) - Escola Politécnica, Universidade de São Paulo, São Paulo, 2009.

ALMEIDA, P. L. et al. Effect of jabuticaba peel extract on lipid oxidation, microbial stability and sensory properties of Bologna-type sausages during refrigerated storage. Meat Science, Amsterdam, v. 110, p.9-14, 2015.

ANGELO, P. M.; JORGE, N. Compostos fenólicos em alimentos - uma breve revisão. Revista do Instituto Adolfo Lutz, São Paulo, v. 66, n. 1, p. 232-240, 2007.

APAK, R. et al. Comparative evaluation of various total antioxidant capacity assays applied to phenolic compounds with the CUPRAC assay. Molecules, Basel, v. 12, p. 1496- 1547, 2007.

ARAÚJO, J. M. A. Química de alimentos: teoria e prática. Viçosa/MG: UFV, 2011, $601 \mathrm{p}$.

ASCHERI, D. P. R.; ASCHERI, J. L. R.; CARVALHO, C. W. P. Caracterização da farinha do bagaço da jabuticaba e propriedades funcionais dos extrusados. Ciência de Tecnologia de Alimentos, Campinas, v. 26, p. 867-905, 2006.

BALASUNDRAM, N.; SUNDRAM, K.; SAMMAN, S. Phenolic compounds in plants and agri-industrial by-products: Antioxidant activity, occurrence, and potential uses. Food Chemistry, Amsterdam, v. 99, p. 191-203, 2006.

BARROS, F. A. R.; STRINGHETA, P. C. Microencapsulamento de antocianinas. Biotecnologia Ciência e Desenvolvimento, Brasília, v. 9 n. 36, 2006. Disponível 
em:<http://biotecnologia.com.br/revista/bio36/microencapsulamento_36.pdf>. Acesso em: 20 ago. 2015.

BENZIE, I. F. F.; STRAIN, J. J. The ferric reducing ability of plasma (FRAP) as a measure of "antioxidant power": The FRAP assay. Analytical Biochemistry, Philadelphia, v. 239, p. 70-76, 1996.

BERASATEGI, I. et al. Healthy reduced-fat Bologna sausages enriched in ALA and DHA and stabilized with Melissa officinalis extract. Meat Science, Amsterdam, v. 96, p. 1185-1190, 2014.

BLIGH, E. G.; DYER, W. J. A rapid method of total lipid extration and purification. Canadian Journal of Biochemistry and Physiology, Ottawa, v. 37, n. 8, p. 911917, 1959.

BLOUKAS, J. G.; ARVANITOYANNIS, I. S.; SIOPI, A. A. Effect of natural colourants and nitrites on colour attribute of frankfurters. Meat Science, Amsterdam, v. 52, n. 3, p. 257-265, 1999.

BORDIGNON-LUIZ, M.T., GAUCHE, C., CRIS, E.F., FALCÃO, L.D. Colour stability of anthocyanins from Isabel grapes (Vitis labrusca L.) in model system. LWT - Food Science and Technology. v.40 n. 4 p.594-599. 2007.

BRAND-WILLIAMS, W.; CUVELIER, M. E.; BERSET. C. Use of a free radical method to evaluate antioxidant activity. LWT - Food Science and Technology, London, v. 28, p. 25-30, 1995.

BRASIL. Instrução Normativa n 4, de 31 de março de 2000. Aprova os Regulamentos Técnicos de Identidade e Qualidade de Carne Mecanicamente Separada, de Mortadela, de Linguiça e de Salsicha. Diário Oficial [da] União, Brasília, DF, 5 abr. 2000. Seção 1, p. 6-10.

BRASIL. Resolução RDC nํ 12, de 02 de janeiro de 2001. Aprova o Regulamento Técnico sobre padrões microbiológicos para alimentos. Diário Oficial [da] União, Brasília, DF, Poder Executivo, 10 jan. 2001.

BREWER, M. S. Natural antioxidants: sources, compounds, mechanisms of action, and potential applications. Comprehensive Reviews in Food Science and Food Safety, Chicago, v. 10, p. 221-247, 2011.

BRIDLE, P.; TIMBERLAKE, C. F. Anthocyanins as natural food colours-selected aspects. Food Chemistry, Amsterdam, v. 58, n. 1-2, p. 103-109. 1997.

CAILLET, S. et al. Antimicrobial effects of fractions from cranberry products on the growth of seven pathogenic bacteria. Food Control, Kidlington, v. 23, p. 419-428, 2012.

CARVALHO, C. M. et al. Efeito antimicrobiano in vitro do extrato de Jabuticaba (Myrciaria cauliflora (Mart.) O. Berg.) sobre Streptococcus da cavidade oral. Revista Brasileira de Plantas Medicinais, Paulínia, v. 11, 79-83, 2009. 
CASTAÑEDA-OVANDO, A. et al. Chemical studies of anthocyanins: a review. Food Chemistry, Amsterdam, v. 113, n. 4, p. 859-871, 2009.

CEREGATTI, A. Cochonilha. 2012. Disponível em:

<http://www.alimentacaovegetariana.com/2012/03/cochonilha.html>. Acesso em: 5 jan. 2016.

CHAVES, F. Há insetos no seu refrigerante? 2012. Disponível em:<https://vistase.com.br/ha-insetos-no-seu-refrigerante/>. Acesso em: 5 jan. 2016.

$\mathrm{CHOU}, \mathrm{P}$. H. et al. Isolation and identification of xenobiotic aryl hydrocarbon receptor ligands in dyeing wastewater. Environmental Science and Technology, Dordrecht, v. 41, n. 2, p. 652-657, 2007.

CÔTÉ, J. et al. Antibacterial effect of cranberry juice and extracts. Food Control, Kidlington, v. 22, p.1413-1418, 2011.

DEGÁSPARI, C. H.; WASZCZYNSKYJ, N. Propriedades antioxidantes de compostos fenólicos. Visão Acadêmica, Curitiba, v. 5, n. 1, p. 33-40, 2004.

DEMIRDOVEN, A.; KARABIYIKLI, S.; ONCÜL, N. Inhibitory effects of red cabbage and sour cherry pomace anthocyanin extracts on food borne pathogens and their antioxidant properties. LWT - Food Science and Technology, London, v. 63, p. 813, 2015.

DOMÉNECH-ASENSI, G. et al. Effect of the addition of tomato paste on the nutritional and sensory properties of mortadella. Meat Science, Amsterdam, v. 93, p. 213-219, 2013.

DONADIO, L. C. Jaboticaba (Myrciaria cauliflora (Vell) Berg). Jaboticabal: Funep, 2000. 55 p.

EIBOND, L. S. et al. Anthocyanin antioxidants from edible fruits. Food Chemistry, Amsterdam, v. 84, n. 1, p. 23, 2004.

EVANGELISTA, J. Tecnologia de alimentos. São Paulo: Atheneu, 2001. 652 p.

FENNEMA, O. R.; DAMODARAN, S.; PARKIN, K. L. Química de alimentos de Fennema. Porto Alegre: Artmed, 2010. 900 p.

GEORGÉ, S. et al. Rapid determination of polyphenols and vitamin C in plantderived products. Journal of Agricultural and Food Chemistry, Washington, v. 53, p. 1370-1373, 2005.

GIUSTI, M. M.; WROLSTAD, R. E. Anthocyanins characterization and measurement with UV - visible spectroscopy. In: WROLSTAD, R. E. (Ed.). Current Protocols in Food Analytical Chemistry. Wiley, New York: Wiley, 2001. p. 1-13.

GOMES, P. Fruticultura brasileira. 9. ed. São Paulo: Nobel, 1983. 446 p. 
GOMES, R. P. A jabuticabeira. In: GOMES, R. P. Fruticultura Brasileira. 12. ed. São Paulo: Nobel, 1972. p. 263-267.

HARBORNE, J. B. Comparative biochemistry of the flavonoids. London: Academic Press, 1967.

HODGES, D. M. et al. Improving the thiobarbituric acid-reactive-substances assay for estimating lipid peroxidation in plant tissues containing anthocyanin and other interfering compounds. Planta, Heidelberg, v. 207, p. 604-611, 1999.

HORWITZ, W.; LATIMER, G. W. Official methods of analysis of AOAC international. 18th ed. Gaithersburg: Association of Official Analytical ChemistsAOAC International, 2007.

JAYAWARDANA, B. C. et al. Utilization of adzuki bean extract as a natural antioxidant in cured and uncured cooked pork sausages. Meat Science, Amsterdam, v. 89 , p. $150-153,2011$.

KING, A.; YOUNG, G. Characteristics and occurence of phenolic phytochemicals. Journal of the American Dietetic Association, New York, v. 99, n. 2, p. 213-218, 1999.

KONCZAK, I.; ZHANG, W. Anthocyanins-more than nature's colours. Journal of Biomedicine and Biotechnology, New York, v. 2004, n. 5, p. 239-240, 2004.

KONG, J. M. et al. Analysis and biological activities of anthocyanins.

Phytochemistry, Kidlington, v. 64, p. 923-933, 2003.

KUSHIDA, M. M. Validação de métodos laboratoriais: avaliação do sistema bax de análise de Salmonella sp em alimentos por reação de polimerase em cadeia (PCR). 2005. 194 f. Tese (Doutorado) - Universidade Estadual de Campinas, Campinas, 2005.

LACOMBE, A. et al. Antimicrobial action of the American cranberry constituents: phenolics, anthocyanins, and organic acids, against Escherichia coli O157: $\mathrm{H} 7$. International Journal of Food Microbiology, Amsterdam, v. 139, p. 102-107, 2010.

LEITE-LEGATTI, A. V. et al. Jaboticaba peel: antioxidant compounds, antiproliferative and antimutagenic activities. Food Research International, Kidlington, v. 49, n. 1, p. 596-603, 2012.

LEMOS, A. L. S. C. As tendências no uso de ingredientes e aditivos para produtos cárneos. Revista CarneTec, Chicago, v. 22 n. 2, p. 50-53, 2015.

LIMA, A. J. B. et al. Caracterização do fruto jabuticaba (Myrciaria cauliflora Berg) e de suas frações. Archivos Latinoamericanos de Nutricion, Caracas, v. 58, n. 4, p. 416-421, 2008. 
LIMA, A. J. et al. Anthocyanins, pigment stability and antioxidant activity in jabuticaba [Myrciaria cauliflora (Mart.) O. Berg]. Revista Brasileira de Fruticultura, Jaboticabal, v. 33, p. 877-887, 2011.

LÓPEZ-MALO, A.; ALZAMORA, S. M.; PALOU, E. Aspergillus flavus growth in the presence of chemical preservatives and naturally occurring antimicrobial compounds. International Journal of Food Microbiology, Amsterdam, v. 99, p.119-128, 2004.

MACEDO-COSTA, M. R. et al. Eficácia do extrato de Myrciaria cauliflora (Mart.) O. Berg. (jabuticabeira) sobre bactérias orais. Revista Brasileira de Farmacognosia, Curitiba, v. 19, p. 565-571, 2009.

MALACRIDA, C. R.; MOTTA, S. Antocianinas em suco de uva: composição e estabilidade. Boletim CEPPA, Curitiba, v. 24, n.1, p. 59-82, 2006.

MARQUES, M. F. Cursos rápidos de tecnologia de produtos cárneos: embutidos finos - série A. Belo Horizonte: SEBRAE-MG, Fundação Centro Tecnológico de Minas Gerais/CETEC. 1994.

MARTIN, J. G. P. et al. Antimicrobial potencial and chemical compositions of agroindustrial wastes. Journal of Natural Products, Washington, v. 5, p. 27-36, 2012.

MARTINEZ, M. Cochonilha. Disponível em:

<http://www.infoescola.com/insetos/cochonilha/>. Acesso em: 5 jan. 2016.

MEILGAARD, M.C.; CIVILLE, G.V.; CARR, B.T. Sensory Evaluation Techniques. 4. ed. Boca Raton: CRC Press, 2006. 448p.

MELO, P. S. et al. Composição fenólica e atividade antioxidante de resíduos agroindustriais. Ciência Rural, Santa Maria, v. 41, n. 6, p. 1088-1093, 2011.

MICHELIN, D. C. et al. Avaliação da atividade antimicrobiana de extratos vegetais. Revista Brasileira de Farmacognosia, Curitiba, v. 15, p. 316-320, 2005.

MIELNIK, M. B. et al. By-products from herbs essential oil production as ingredient in marinade for turkey thighs. LWT - Food Science and Technology, London, v. 41, p. 93-100, 2008.

MUNEKATA, P. E. S. et al. Peanut skin extract reduces lipid oxidation in cooked chicken patties. Poultry Science, Cary, v. 94, p. 442-446, 2015.

NCCLS. Methods for dilution antimicrobial susceptibility tests for bacteria that grow aerobically: approved standard. $6^{\text {th }}$ ed. NCCLS document M7-A6. Wayne, PA:

Clinical and Laboratory Standards Institute, 2003.

NOVAIS, T. S. et al. Atividade antibacteriana em alguns extratos de vegetais do semi-árido brasileiro. Revista Brasileira de Farmacognosia, Curitiba, v. 13, p. 5-8, 2003. 
NUNES, J. S. et al. Obtenção e caracterização físico-química de polpa de jabuticaba (Myrciaria cauliflora Berg) congelada. Revista Verde, Mossoró - RN, v. 9, n. 1, p. 234-237, 2014.

OLIVEIRA, L. F. et al. Aproveitamento alternativo da casca do maracujá-amarelo (Passiflora edulis F. FLAVICARPA) para produção de doce em calda. Ciência e Tecnologia de Alimentos, Campinas, v. 22, n. 3, p. 259-262, 2002.

OLIVEIRA, A. L. et al. Caracterização tecnológica de jabuticabas Sabará provenientes de diferentes regiões de cultivo. Revista Brasileira de Fruticultura, Jaboticabal, v. 25, p. 397-400, 2003.

ORDAZ-GALINDO, A. et al. Purification and identification of Capulin (Prunus serotina Ehrh) anthocyanins. Food Chemistry, Amsterdam, v. 65, p. 201-206, 1999.

OZVURAL, E.B.; VURAL, H. The effects of grape seed extract on quality characteristics of frankfurters. Journal of Food Processing and Preservation, v.36, p.291-297, 2012.

Produtos cárneos. In: ORDÓÑEZ, J. A. P. et al. Tecnologia de alimentos: alimentos de origem animal. Porto Alegre: Artmed, 2005a. v.2. p.187-208.

Lípideos. In: ORDÓÑEZ, J.A.P. et al. Tecnologia de alimentos: alimentos de origem animal. Porto Alegre: Artmed, 2005b. v.1. p.33- 49.

PEREIRA, A. L. F. et al. Estabilidade oxidativa de mortadelas contendo extrato da casca da manga (Mangifera indica L.). Brazilian Journal of Food Technology, Campinas, v. 13, n. 4, p. 293-298. 2010.

PEREIRA, J. Tecnologia e qualidade de cereais: arroz, trigo, milho e aveia. Lavras: UFLA/FAEPE, 2002.

PEREIRA, M. C. T. et al. Atributos físicos e químicos de frutos de oito clones de jabuticabeiras. Revista Brasileira de Fruticultura, Jaboticabal, v. 22, p. 16-21, 2000.

PÉREZ-JIMÉNEZ, J. et al. Updated methodology to determine antioxidant capacity in plant foods, oils and beverages: extraction, measurement and expression of results. Food Research International, Kidlington, v. 41, p. 274-285, 2008.

PHAM, A.J. et al. Effects of rosemary (Rosmarinus officinalis L.) and green tea (Camella sinensis L.) extracts on overall quality and shelf-life of fresh pork sausage during long-term frozen storage and retail display. Meat Science, v. 96(1), p. 447448, 2014.

PORTO, E. Microbiologia de carnes. In: CASTILHO, C. J. C. Qualidade da carne. São Paulo: Varela, 2006. p.101-127. 
QI, S. et al. Lychee (Litchi chinensis Sonn.) seed water extract as potential antioxidant and anti-obese natural additive in meat products. Food Control, Kidlington, v. 50, p. 195-201, 2015.

RAMALHO, V. C.; JORGE, N. Antioxidantes utilizados em óleos, gorduras e alimentos gordurosos. Química Nova, São Paulo, v. 29, n. 4, p. 755-760, 2006.

REYNERTSON, K. A. et al. Quantitative analysis of antiradical phenolic constituents from fourteen edible Myrtaceae fruits. Food Chemistry, Amsterdam, v. 109, n. 4, p. 883-890, 2008.

RICE-EVANS, C. A.; MILLER, J. M.; PAGANGA, G. Structure-antioxidant activity relationship of flavonoids and phenolic acids. Free Radical Biology \& Medicine, Philadelphia, v. 20, p. 933-956, 1996.

RICE-EVANS, C. A., MILLER, J. M., PAGANGA, G. Antioxidant properties of phenolic compounds. Trends in Plant Science, Kidlington, v. 2, n. 4, p. 152-159, 1997.

ROCKENBACH, I. I. et al. Phenolic compounds content and antioxidant activity in pomace from selected red grapes (Vitis vinifera L. and Vitis labrusca L.) widely produced in Brazil. Food Chemistry, Amsterdam, v. 127, n. 1, p. 174-179, 2011.

ROMANS, J. R. et al. The meat we eat. Danville, Illinois: Interstate Publishers, Inc. 2001. p. $779-888$.

SALEM, F. M. A.; IBRAHIM, H. M. Dry fermented buffalo sausage with sage oil extract: safety and quality. Grasas Y Aceites, Sevilla, v. 61, n. 1, p. 76-85, 2010.

SANTOS, D. T.; VEGGI, P. C.; MEIRELES, M. A. A. Extraction of antioxidant compounds from jabuticaba (Myrciaria cauliflora) skins: yield, composition and economical evaluation. Journal of Food Engineering, London, v. 11, p. 23-31, 2010.

SATO, A. C. K.; CUNHA, R. L. Effect of particle size on rheological properties of jaboticaba pulp. Journal of Food Engineering, London, v. 91, p. 566-570, 2009.

SEIFRIED, H. E. et al. A review of the interaction among dietary antioxidants and reactive oxygen species. The Journal of Nutritional Biochemistry, New York, v. 18, n. 9, p. 567-579, 2007.

SHAHIDI, F.; HAN, X. Q. Encapsulation of food ingredients. Critical Reviews in Food Science and Nutrition, New York, v. 33, n. 6, p. 501-547, 1993.

SHAHIDI, F.; WANASUNDARA, P. D. Phenolic antioxidants. Critical Rewiews in Food Science and Nutrition, New York, v. 32, n. 1, p. 67-103, 1992.

SHIRAHIGUE, L. D. et al. Wine industry residue as antioxidant in cooked chicken meat. International Journal of Food Science and Technology, Chichester, v. 45, p. 863-870, 2010. 
SILVA, J. G. et al. Atividade antimicrobiana do extrato de Anacardium occidentale Linn. em amostras multiresistentes de Staphylococcus aureus. Revista Brasileira de Farmacognosia, Curitiba, v. 17, n. 4, p. 572-577, 2007.

SILVA, G. J. F. et al. Formulação e estabilidade de corantes de antocianinas extraídas das cascas de jabuticaba (Myrciaria ssp.). Alimentos e Nutrição, São Paulo, v. 21 n. 3, p. 429-436. 2010a.

SILVA, N. et al. Manual de métodos de análise microbiológica de alimentos e água. 4th ed. São Paulo: Varella, 2010b. 614 p.

SILVA, F. C. et al. Assessment of production efficiency, physicochemical properties and storage stability of spray-dried propolis, a natural food additive, using gum Arabic and OSA starch-based carrier systems. Food and Bioproducts Processing, London, v. 91, p. 28-36, 2013.

SILVA, M. C. et al. Use of the jabuticaba (Myrciaria cauliflora) depulping residue to produce a natural pigment powder with functional properties. LWT - Food Science and Technology, London, v. 55, p. 203-209, 2014.

SOARES, S. E. Ácidos fenólicos como antioxidantes. Revista de Nutrição, Campinas, v. 15, n. 1, p. 71-81, 2002.

STEFANELLO, F. L. et al. Efeito da adição de extrato de cogumelo do sol em linguiça suína e avaliação da estabilidade oxidativa e microbiológica do produto. Semina: Ciências Agrárias, Londrina, v. 36, n. 1, p. 171-186, 2015.

TERCI, D. B. L.; ROSSI, A. V. Indicadores naturais de ph: usar papel ou solução? Quimica Nova, São Paulo, v. 25, n. 4, p. 684-688, 2002.

TERCI, D. B. L. Aplicações analíticas e didáticas de antocianinas extraídas de frutas. 2004. 231 f. Tese (Doutorado em Química Analítica) - Instituto de Química, Universidade Estadual de Campinas, Campinas, 2004.

TERRA, N. N. Apontamentos de tecnologia de carnes. São Leopoldo: Universidade do Vale do Rio dos Sinos - UNISINOS, 1998. 216 p.

VIUDA-MARTOS, M. et al. Effect of added citrus fibre and spice essential oils on quality characteristics and shelf-life of mortadela. Meat Science, Amsterdam, v. 85, p. 568-576, 2010.

VOCÊ CONHECE este inseto? Não? Deveria! Você o come todos os dias e nem sabia. Jornal Ciência, São Paulo, 01 ago. 2012. Disponível em:

<http://www.jornalciencia.com/saude/mente/1940-carmim-de-cochonilha-corantealimenticio-feito-de-insetos.html>. Acesso em: 5 jan. 2016. 


\section{APÊNDICE}




\section{APÊNDICE A - Termo de consentimento livre e esclarecido}

\section{Termo de consentimento livre e esclarecido}

Consentimento formal de participação no projeto de pesquisa: " Avaliação da estabilidade microbiológica e oxidativa de produtos cárneos adicionados de corante natural obtido do resíduo do despolpamento da jabuticaba (Myrciaria cauliflora) microencapsulado com maltodextrina".

Nome: Marco Antonio Trindade

Endereço: Rua Duque Caxias Norte, 255

Cidade: Pirassununga CEP: 13635900 Fone:19 35654245

Justificativa: Os produtos cárneos apresentam grande aceitação pelos consumidores, constituindo-se num importante mercado para as indústrias do setor. Como tem aumentado o interesse pela utilização de pigmentos naturais na alimentação em substituição aos artificiais, a utilização do extrato de jabuticaba aplicado em embutidos, o qual além da coloração também apresenta atividade antioxidante e antimicrobiana pode ser um substituto do corante carmim de cochonilha comercialmente empregado.

Objetivos do projeto: Avaliar o potencial antimicrobiano e antioxidante do extrato de jabuticaba (Myrciaria cauliflora) aplicado em embutidos tipo linguiça frescal e mortadela, em substituição aos corantes normalmente utilizados e avaliar a aceitação sensorial desses embutidos.

\section{Procedimentos:}

A análise onde seres humanos avaliam diversos atributos de qualidade de alimentos é chamada de ANÁLISE SENSORIAL. Os procedimentos para execução da análise sensorial nesta pesquisa serão os seguintes:

- Sessenta provadores farão a avaliação sensorial dos produtos.

- Serão testadas diferentes formulações dos embutidos cárneos.

- O provador deverá avaliar (olhar, cheirar, provar) os produtos e responder às perguntas solicitadas na Ficha de Avaliação.

- A duração do teste para cada pessoa será de aproximadamente 10 minutos.

\section{Outras informações:}

- O provador pode se recusar a continuar com a avaliação sensorial a qualquer momento, sem penalização alguma e sem prejuízo ao seu cuidado. 
- Os provadores não terão qualquer tipo de despesas em decorrência da participação nesta pesquisa.

- Não há possibilidade de risco ou qualquer tipo de desconto em função da participação nesta pesquisa, uma vez que todos os ingredientes utilizados nos produtos são inteiramente seguros e serão de boa qualidade e procedência e o processo de fabricação será realizado de acordo com as normas de Boas Práticas de Fabricação.

- Em função do exposto no item anterior, não há previsão de indenização em decorrência da participação neste projeto.

- Os testes para avaliação sensorial das linguiças frescais e mortadelas, nos quais os provadores experimentarão os produtos desenvolvidos serão acompanhados pelo pesquisador proponente (Prof. Dr. Marco Antonio Trindade).

- Quaisquer outros esclarecimentos poderão ser solicitados antes, durante e após a pesquisa.

$\mathrm{Eu}$,

, RG CPF abaixo assinado, concordo em participar do estudo “Avaliação da estabilidade microbiológica e oxidativa de produtos cárneos adicionados de corante natural obtido do resíduo do despolpamento da jabuticaba (Myrciaria cauliflora) microencapsulado com maltodextrina".

Tenho pleno conhecimento da justificativa, objetivos, benefícios esperados e dos procedimentos a serem executados, bem como da possibilidade de receber esclarecimentos sempre que considerar necessário. Será mantido sigilo quanto à identificação de minha pessoa e zelo a minha privacidade. Ao mesmo tempo assumo o compromisso de seguir as recomendações estabelecidas pelos pesquisadores.

Eu li e entendi todas as informações contidas neste documento.

Pesquisador Responsável: Prof. Dr. Marco Antonio Trindade.

Contato: trindadema@usp.br

Pirassununga, de de Assinatura: 